\title{
Employability in bedrijf: naar een employability index voor bedrijfssectoren : themarapport werkgelegenheid en scholing 1998
}

Citation for published version (APA):

de Grip, A., van Loo, J. B., \& Sanders, J. M. A. F. (1998). Employability in bedrijf: naar een employability index voor bedrijfssectoren : themarapport werkgelegenheid en scholing 1998. Researchcentrum voor Onderwijs en Arbeidsmarkt, Faculteit der Economische Wetenschappen. ROA Reports No. 10 https://doi.org/10.26481/umarep.1998010

Document status and date:

Published: 01/01/1998

DOI:

10.26481/umarep.1998010

Document Version:

Publisher's PDF, also known as Version of record

Please check the document version of this publication:

- A submitted manuscript is the version of the article upon submission and before peer-review. There can be important differences between the submitted version and the official published version of record.

People interested in the research are advised to contact the author for the final version of the publication, or visit the DOI to the publisher's website.

- The final author version and the galley proof are versions of the publication after peer review.

- The final published version features the final layout of the paper including the volume, issue and page numbers.

Link to publication

\footnotetext{
General rights rights.

- You may freely distribute the URL identifying the publication in the public portal. please follow below link for the End User Agreement:

www.umlib.nl/taverne-license

Take down policy

If you believe that this document breaches copyright please contact us at:

repository@maastrichtuniversity.nl

providing details and we will investigate your claim.
}

Copyright and moral rights for the publications made accessible in the public portal are retained by the authors and/or other copyright owners and it is a condition of accessing publications that users recognise and abide by the legal requirements associated with these

- Users may download and print one copy of any publication from the public portal for the purpose of private study or research.

- You may not further distribute the material or use it for any profit-making activity or commercial gain

If the publication is distributed under the terms of Article $25 \mathrm{fa}$ of the Dutch Copyright Act, indicated by the "Taverne" license above, 


\section{Employability in bedrijf: naar een Employability Index voor Bedrijfssectoren}

\section{Themarapport \\ Werkgelegenheid en scholing 1998}

ROA-R-1998/10

Andries de Grip

Jasper van Loo

Jos Sanders

Researchcentrum voor Onderwijs en Arbeidsmarkt

Faculteit der Economische Wetenschappen en Bedrijfskunde

Universiteit Maastricht

Maastricht, december 1998 
ISBN 90-5321-237-X

SEC98.138/AdG 


\section{Inhoud}

Bladzijde

Voorwoord ii

Resumé

1 Inleiding 1

1.1 Inleiding 1

1.2 Doel van het rapport 2

1.3 Fase 1: Actuele inzetbaarheid 3

1.4 Fase 2: Ontwikkelingen in de maatschappelijke context 4

1.5 Fase 3: Confrontatie 4

1.6 Fase 4: Effectueringscondities 4

1.7 Fase 5: Sectorale Employability Index (S.E.I.) 5

2 Individuele employability $\quad 7$

$\begin{array}{ll}2.1 \text { Inleiding } & 7\end{array}$

$\begin{array}{ll}2.2 \text { Indicatoren voor individuele employability } & 7\end{array}$

$\begin{array}{ll}2.3 \text { Operationalisatie van de concepten } & 11\end{array}$

2.4 Gebruikte databronnen voor de M.O.I. $\quad 15$

$\begin{array}{ll}2.5 \text { Samenvatting en conclusie } & 18\end{array}$

3 Individuele employability per bedrijfssector 21

3.1 Inleiding $\quad 21$

3.2 Mobiliteitsbereidheid en -vermogen $\quad 21$

3.3 Opleidingsbereidheid en -vermogen $\quad 24$

3.4 Bereidheid en vermogen tot brede inzetbaarheid 28

$\begin{array}{ll}3.5 \text { M.O.I. per bedrijfssector } & 31\end{array}$

4 Maatschappelijke ontwikkelingen en behoefte aan employability $\begin{array}{ll}\text { per bedrijfssector } & 37\end{array}$

$\begin{array}{ll}4.1 \text { Inleiding } & 37\end{array}$

$\begin{array}{ll}\text { 4.2 Maatschappelijke ontwikkelingen } & 37\end{array}$

4.3 Technologische ontwikkelingen 41

$\begin{array}{ll}4.4 \text { Organisatorische ontwikkelingen } & 42\end{array}$

4.5 Economische ontwikkelingen $\quad 43$

4.6 Demografische ontwikkelingen $\quad 44$

4.7 Employability behoefte per bedrijfssector $\quad 45$

5 Aanwezige en gevraagde employability $\quad 47$

$\begin{array}{ll}5.1 \text { Inleiding } & 47\end{array}$

5.2 Aanbod van en behoefte aan employability: alle werknemers 47 
5.3 Aanbod van en behoefte aan employability: vrouwen

5.4 Aanbod van en behoefte aan employability: jongeren

5.5 Aanbod van en behoefte aan employability: ouderen

5.6 Aanbod van en behoefte aan employability: laag opgeleiden

5.7 Conclusies

6 Effectueringscondities per bedrijfssector 53

6.1 Inleiding 53

6.2 Scholingsmogelijkheden per bedrijfssector 53

6.3 Uitbreidingsvraag per bedrijfssector $\quad 55$

6.4 Effectueringscondities per bedrijfssector 56

7 De Sectorale Employability Index 59

$\begin{array}{ll}7.1 \text { Inleiding } & 59\end{array}$

7.2 S.E.I. per bedrijfssector: alle werknemers $\quad 60$

$\begin{array}{ll}\text { 7.3 S.E.I. per bedrijfssector: vrouwen } & 61\end{array}$

$\begin{array}{ll}7.4 \text { S.E.I. per bedrijfssector: jongeren } & 62\end{array}$

$\begin{array}{ll}\text { 7.5 S.E.I. per bedrijfssector: ouderen } & 63\end{array}$

7.6 S.E.I. per bedrijfssector: laag opgeleiden 64

$\begin{array}{ll}7.7 \text { Conclusies } & 65\end{array}$

$\begin{array}{ll}\text { Literatuur } & 67\end{array}$

$\begin{array}{lr}\text { Bijlage: Berekening S.E.I. } & 69\end{array}$ 


\section{Voorwoord}

Employability in bedrijf: naar een Employability Index voor Bedrijfssectoren is het eerste themarapport in het kader van het Werkgelegenheid en Scholing Observatorium (WSO) van het Researchcentrum voor Onderwijs en Arbeidsmarkt (ROA). Dit observatorium is door het Ministerie van Sociale Zaken en Werkgelegenheid ingesteld in het kader van de stimuleringsprogramma's ESF-4 Scholing voor behoud van werk en ADAPT van de Europese Commissie.

Het observatorium heeft als doel de voor het scholingsbeleid relevante ontwikkelingen op continue basis in beeld te brengen. Het WSO fungeert daarbij als een centraal punt, waar de relevante ontwikkelingen en prognoses met betrekking tot de werkgelegenheid en kwalificatiebehoeften met elkaar in verband worden gebracht, om zo tijdig inzicht te krijgen in de scholingsactiviteit binnen branches en bedrijven en de lacunes die op dit punt bestaan.

In de vorige twee rapportages van het WSO is de WSO-thematiek integraal in beeld gebracht. Dit rapport belicht daarentegen slechts één thema: het in beeld brengen van de employability van de werknemers in de diverse bedrijfssectoren.

Dit rapport heeft een tweeledig karakter. Enerzijds is het een onderzoek naar de vraag hoe de employability van de werkenden in de verschillende bedrijfssectoren het best gekarakteriseerd kan worden. Dit met het oog op de verdere verbeteringen van toekomstige integrale WSO-rapportages 'Werkgelegenheid en Scholing'. Anderzijds kunnen de gepresenteerde cijfers reeds direct inzicht bieden in de feitelijke 'employability gerichtheid' van de diverse bedrijfssectoren.

De leiding van dit project was in handen van dr. A. de Grip. Daarnaast is aan het onderzoek meegewerkt door drs. J.B. van Loo en drs. J.M.A.F. Sanders. Onze dank gaat uit naar de leden van de begeleidingscommissie. Deze commissie bestaat uit de volgende leden: drs. M.G. Drewes, drs. F. Straatjes en drs. J.C. van der Velden. 


\section{Resumé}

Employability in bedrijf: naar een Employability Index voor bedrijfssectoren is het eerste themarapport van het Werkgelegenheid en Scholing Observatorium (WSO) 1998. In de twee vorige WSO-rapporten (De Grip cs. 1997 en ROA, 1998a) is de WSO-thematiek, gericht op de risico's op verlies van werk en de betekenis van scholingsactiviteiten ter verbetering van de perspectieven, integraal in beeld gebracht. Daarentegen belicht dit rapport één enkel thema: het in beeld brengen van de employability van de werknemers in de diverse bedrijfssectoren.

Het rapport heeft een tweeledig karakter. Enerzijds is het een eerste onderzoek naar de vraag hoe de employability van de werkenden in de verschillende bedrifssectoren het best gekarakteriseerd kan worden. Anderzijds kunnen de gepresenteerde cijfers inzicht bieden in de 'employability gerichtheid' van sectoren.

De employability van werkenden staat op het moment volop in de belangstelling. Zowel bedrijven als de overheid besteden er in toenemende mate aandacht aan. In het overzichtsrapport Werkgelegenheid en scholing 1997 wordt employability, naast het bevorderen van scholingsinspanningen, genoemd als remedie tegen diverse vormen van kwalificatieveroudering. Employability wordt daarbij gezien als het in staat zijn en de wens hebben om blijvend aantrekkelijk te zijn voor de arbeidsmarkt, door te reageren en te anticiperen op veranderingen in arbeidstaken en werkomgeving. Het centrale idee in dit rapport is dat de employability van werknemers mede afhankelijk is van de bedrijfssector waarin men werkzaam is. Het doel van dit rapport is dan ook om een index (de Sectorale Employability Index, of S.E.I.) te ontwikkelen die een beeld geeft van de employability per bedrijfssector. Deze index wordt zowel voor de gehele werknemerspopulatie alsmede voor een aantal specifieke doelgroepen bepaald.

\section{Het S.E.I. model}

De S.E.I. kan gebruikt worden om bedrijfssectoren op het punt van de employability van de werkenden te vergelijken. Maar minstens zo belangrijk is de potentiële 'benchmark-functie' van de index. Bedrijven zouden in principe met soortgelijke gegevens over hun eigen personeel en de eigen organisatie een index op bedrijfsniveau kunnen berekenen en die vergelijken met de index voor de gehele sector, om zo te komen tot een inschatting van de eigen positie ten opzichte van de andere bedrijven in de sector. De index belicht een aantal facetten die bepalend zijn voor de employability van de werkenden in de diverse bedrijfssectoren:

1 de aanwezige employability per bedrijfssector;

2 de employability behoefte per bedrijfssector;

3 de confrontatie van de aanwezige employability en de employability behoefte;

4 de 'effectueringscondities'. 


\section{Aanwezige employability per bedrijfssector}

De aanwezige employability van werknemers in bedrijfssectoren wordt gekarakteriseerd aan de hand van een zestal employability-indicatoren, die tezamen de M.O.I.-index (Mobiliteit, Opleiding en Inzetbaarheid) vormen. De index bevat zowel bereidheids- als vermogensaspecten en geeft daarom vrij compleet beeld van de employability van werknemers.

Wanneer gekeken wordt naar de individuele employability van de gehele werknemerspopulatie in de diverse sectoren dan blijkt dat de werknemers die in de sectoren horeca, reparatie en zakelijke dienstverlening en bank- en verzekeringswezen werkzaam zijn de beste individuele employability hebben. Werknemers die werkzaam zijn in de sectoren landbouw en visserij, transport en communicatie of in de kwartaire diensten, zijn daarentegen het minst 'employable'.

Wanneer wordt gekeken naar de individuele employability van de werkenden die behoren tot een bepaalde doelgroep, valt allereerst op dat vrouwen in de sector landbouw en visserij erg goed scoren. Bij de jongere werknemers (16-29 jarigen) is de employability het grootst in de sectoren bank- en verzekeringswezen, energie en overheid en onderwijs. Verder hebben oudere werknemers (50-64 jarigen) in bijna alle bedrijfssectoren een lagere individuele employability dan hun jongere collega's. In de bedrijfssectoren transport en communicatie en chemie is de situatie voor de oudere werknemers het minst gunstig. Daarentegen is de employability van oudere werknemers in de sector landbouw en visserij veel beter. Ook laag opgeleiden hebben in vrijwel alle bedrijfssectoren een lagere individuele employability dan hoog opgeleide werknemers. Uitzondering hierop vormt de sector overheid en onderwijs, waar laag opgeleiden ongeveer dezelfde mate van individuele employability hebben als middelbaar en hoger opgeleiden. De laagopgeleide werknemers in de bedrijfssectoren voeding, kwartaire diensten en transport en communicatie scoren qua employability het slechtst.

\section{Behoefte aan employability per bedrijfssector}

De toenemende belangstelling voor de employability van werknemers valt met name te verklaren uit het feit dat er zich in de maatschappij een aantal belangrijke ontwikkelingen voordoen die de behoefte aan employability vergroten. Het gaat dan om technologische, economische, organisatorische en demografische ontwikkelingen. Al deze ontwikkelingen doen een toenemend beroep op de employability van werknemers.

De behoefte aan 'employable' werknemers is het grootst in de bedrijfssectoren energie en chemie. In de energiesector doen alle bovengenoemde ontwikkelingen zich voor. Voor werknemers in de chemie geldt dat ze in sterke mate te maken krijgen 
met drie van de vier genoemde maatschappelijke ontwikkelingen. In deze sector spelen technologische vernieuwingen, economische ontwikkelingen en demografische trends een grote rol. Daarentegen zijn de organisatorische veranderingen in de sector minder van belang.

Organisatorische en demografische ontwikkelingen zorgen ervoor dat de sectoren metaal en elektrotechniek en overheid en onderwijs qua employability behoefte de derde en vierde plaats innemen.

In de bedrijfssectoren handel en bouw en onroerend goed is de behoefte aan werknemers met een goede employability het geringst. Voor werknemers in laatstgenoemde bedrijfssector spelen geen van de genoemde maatschappelijke ontwikkelingen een noemenswaardige rol. In de handel zijn alleen technologische ontwikkelingen enigszins van belang.

\section{Confrontatie van de aanwezige employability en behoefte aan employability}

De gemiddelde individuele employability van werknemers en de behoefte aan employability in de diverse sectoren worden in de derde stap van de totstandkoming van de S.E.I. aan elkaar gerelateerd. Dit om te komen tot een inschatting van de mate waarin de sectorale employability behoefte afgestemd is op de aanwezige employability van de werknemers.

Uit de confrontatie van de aanwezige employability en de behoefte daaraan blijkt dat, wanneer gekeken wordt naar de gehele werknemerspopulatie, de verhouding tussen de behoefte en het 'aanbod' van employability het gunstigst is in de sector bouw en onroerend goed. Ook in de handel en het bank- en verzekeringswezen is deze verhouding gunstig. Sectoren waarin een grote behoefte aan 'employable' werknemers gepaard gaat met een relatief lage employability van de werknemers zijn transport en communicatie, energie en overheid en onderwijs.

Wanneer de confrontatie van de individuele employability en de sectorale behoefte aan employability alleen voor de in de sector werkzame vrouwen plaatsvindt, blijkt dat de situatie gunstig is in de sectoren bank- en verzekeringswezen, bouw en onroerend goed en landbouw en visserij. De sectoren waar de employability behoefte daarentegen hoog is ten opzichte van de aanwezige employability van de in de sector werkzame vrouwen zijn transport en communicatie, overheid en onderwijs en metaal en elektrotechniek.

Bij de jongere werknemers is de verhouding tussen de employability behoefte en de aanwezige employability het gunstigst in het bank- en verzekeringswezen. In de landbouw en visserij is deze verhouding bij de jongeren het minst gunstig. 
Voor de laag opgeleiden valt de confrontatie van de employability van de werknemers met de sectorale employability behoefte het gunstigst uit bij de bedrijfssectoren bouw en onroerend goed en handel. Deze confrontatie valt daarentegen een stuk minder gunstig uit voor laag opgeleiden in de bedrijfssectoren energie, chemie, transport en communicatie en voeding.

\section{Effectueringscondities per bedrijfssector}

Effectueringscondities zijn te omschrijven als de omstandigheden waaronder werknemers binnen organisaties tot een optimale invulling en effectuering van hun individuele employability kunnen komen. Het gaat in deze vierde stap in de berekening van de Sectorale Employability Index om de effectueringscondities van contextuele aard. Deze effectueringscondities zijn in het S.E.I. model opgenomen om de mogelijkheden, die werknemers hebben om hun employability binnen een bedrijfssector te effectueren, in kaart te brengen.

Er worden in het S.E.I. model twee effectueringscondities opgenomen. Daarbij gaat het enerzijds om de scholingsinspanningen in de sector. Deze geven aan in hoeverre werknemers de kans krijgen zich te scholen. Anderzijds gaat het om de verwachte werkgelegenheidsontwikkeling ('uitbreidingsvraag') voor de komende jaren, die een inschatting geeft van de mate waarin werknemers vanwege de werkgelegenheidsgroei binnen een sector van baan kunnen veranderen. Deze effectueringscondities worden gecombineerd tot één indicator, die een globaal beeld geeft van de mogelijkheden die er binnen een bedrijfssector bestaan om de employability te effectueren.

Uit de gegevens blijkt dat de effectueringscondities in het bank-en verzekeringswezen het gunstigst zijn. Dit is met name toe te schrijven aan de intensiteit van de scholingsactiviteiten in deze sector. Ook in de sectoren horeca, reparatie en zakelijke dienstverlening en chemie is sprake van relatief gunstige effectueringscondities. In tegenstelling tot de andere sectoren zijn de effectueringscondities in de horeca echter niet gunstig als gevolg van grote scholingsinspanningen, maar door de relatief hoge uitbreidingsvraag.

\section{De Sectorale Employability Index}

Bij het bepalen van de S.E.I. wordt met alle bovenstaande facetten rekening gehouden. Daarbij wordt de employability aanbod/behoefte verhouding gecombineerd met de effectueringscondities, om zo te kunnen komen tot een inschatting van de mate waarin de effectueringscondities afgestemd zijn op eventuele discrepanties tussen de employability van de werknemers en de behoefte aan employability in de diverse sectoren. Als in een bedrijfssector de behoefte aan werknemers met een hoge employability klein is, terwijl de employability van de werknemers groot is en er 
bovendien sprake is van relatief gunstige effectueringscondities, dan zal de S.E.I. hoog zijn.

De sector bank- en verzekeringswezen scoort het best op de index. In deze sector is de behoefte aan employability van de werknemers beperkt. Ook de sectoren bouw en onroerend goed en zakelijke dienstverlening hebben een relatief gunstige S.E.I. De sector met de minst gunstige employability-score is de landbouw en visserij. Daarnaast scoren ook de bedrijfssectoren transport en communicatie en energie vrij ongunstig op de S.E.I.

Om de relatieve positie van de specifieke doelgroepen (vrouwen, oudere en jongere werknemers en laag opgeleiden) van de werknemers inzichtelijker te maken is in de onderstaande figuur de S.E.I. voor de verschillende doelgroepen afgezet tegen de S.E.I. voor de gehele werknemerspopulatie in de diverse sectoren. De rand van het grijze vlak geeft de S.E.I.-score voor de gehele werknemerspopulatie. Naarmate de employability van de werknemers in een sector gunstiger is, ligt de rand van dit vlak verder van het middelpunt. De lijnen in de figuur geven de waarden voor de S.E.I. van de doelgroepen. Zo wordt het bijvoorbeeld duidelijk dat in de bedrijfssector chemie jongere werknemers beter dan het gemiddelde scoren, dat vrouwen een gemiddelde S.E.I. hebben, en dat ouderen en laag opgeleiden onder het gemiddelde scoren. Voor de overige sectoren kan de relatieve positie van de doelgroepen ook eenvoudig bepaald worden door de S.E.I. van de doelgroepen te vergelijken met de S.E.I. van de gehele werknemerspopulatie.

Figuur

De S.E.I. voor de gehele werknemerspopulatie en de doelgroepen

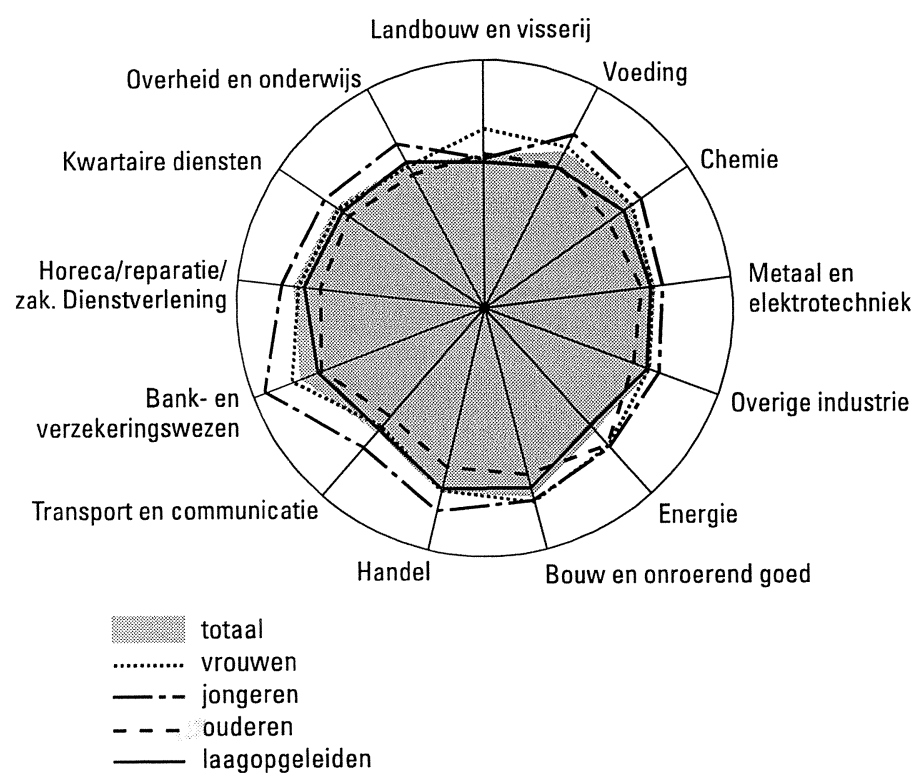




\section{Inleiding}

\subsection{Inleiding}

Employability staat de laatste tijd in het brandpunt van de belangstelling. Uit een onderzoek van Coopers, Lybrand en Berenschot (Tooren cs, 1996) blijkt dat in $90 \%$ van de bedrijven op een of andere wijze aandacht wordt geschonken aan de employability van het personeel. Ook van overheidswege is er volop aandacht voor de employability van de beroepsbevolking, getuige het recentelijk afgeronde Nationaal actieprogramma 'Een leven lang leren', een vervolgactie op het kennisdebat. Voor het actieprogramma geldt dat een leven lang leren één van de middelen is om employability voor iedereen te bereiken. In het actieprogramma worden naast een leven lang leren ook werkervaring, erkenning van kwalificaties en leren op de werkplek als middelen daartoe aangereikt. Daarbij wordt er van uitgegaan dat dit een gezamenlijke inspanning vergt van overheid, sociale partners, werkgevers, werknemers en werkzoekenden.

In het overzichtsrapport Werkgelegenheid en scholing 1997 (ROA, 1998a) wordt de employability van de werkenden, naast het bevorderen van scholingsparticipatie, genoemd als remedie tegen diverse vormen van kwalificatieveroudering. Employability wordt daarbij gedefinieerd als het in staat zijn en de wens hebben blijvend aantrekkelijk te zijn voor de arbeidsmarkt, door te reageren en te anticiperen op veranderingen in arbeidstaken en werkomgeving.

De employability van werknemers is onder andere afhankelijk van de bedrijfssector waarin men werkzaam is. Dat idee zal in dit rapport centraal staan. Het doel van het rapport is het ontwikkelen van een employability index per bedrijfssector: de Sectorale Employability Index (S.E.I.). In dit hoofdstuk wordt de ontwikkeling van deze index kort beschreven. Eerst zal in paragraaf 1.2 worden ingegaan op het doel van dit rapport. Daarna zal achtereenvolgens kort worden ingegaan op de verschillende fases van het model dat ten grondslag ligt aan de Sectorale Employability Index (zie figuur 1.1). In paragraaf $1.3 \mathrm{komt}$ de eerste fase van het onderzoek, het bepalen van de actuele inzetbaarheid van werknemers per bedrijfssector (de sector M.O.I.) aan de orde. In paragraaf 1.4 wordt fase 2 besproken. Het gaat hier om het bepalen van de voor een sector relevante maatschappelijke ontwikkelingen, die voor een belangrijk deel de behoefte aan werknemers met een goede employability bepalen. In paragraaf 1.5 wordt de confrontatie tussen de actuele inzetbaarheid en de employability behoefte op basis van de relevante maatschappelijke ontwikkelingen besproken (fase 3). De mogelijkheden om de actuele inzetbaarheid te effectueren (de 'effectueringscondities'), vormen de vierde fase van het S.E.I.-model en komen aan de orde in paragraaf 1.6. Ten slotte wordt in paragraaf 1.7 fase 5 , het bepalen van de uiteindelijke S.E.I., besproken. 
Figuur 1.1

Fase-indeling bij het onderzoek naar de employability-gerichtheid per sector.

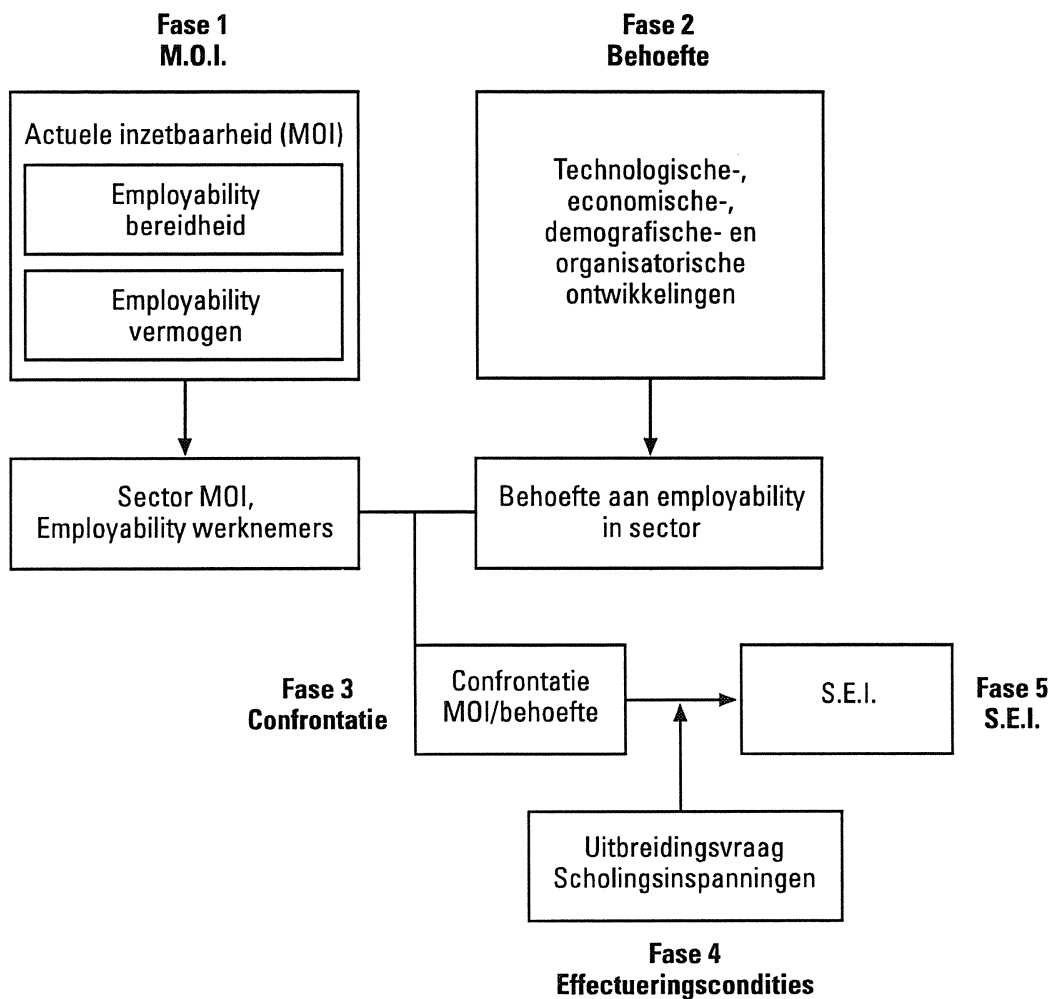

\subsection{Doel van het rapport}

Het doel van dit rapport is het verkrijgen van inzicht in hoe het binnen de verschillende bedrijfssectoren gesteld is met de employability van de werknemers. Daartoe wordt een index ontwikkeld waarmee sectoren tegen elkaar afgezet kunnen worden. Deze index zal daarnaast voor individuele organisaties binnen een bedrijfssector een belangrijke benchmark-functie kunnen vervullen bij de ontwikkeling van een employability-beleid. Organisaties kunnen, gebruik makend van eigen bedrijfsgegevens, de employability van het eigen personeel vergelijken met het sectorgemiddelde. Ten slotte kan de index ook voor individuele werknemers een praktisch nut hebben, daar de index een indicatie verschaft van de mogelijkheden die de verschillende bedrijfssectoren bieden voor de ontwikkeling van de eigen employability.

De index die in dit rapport wordt ontwikkeld, kan wellicht ook gerelateerd worden aan de Investors in People-standaard. Dit Britse employability keurmerk is ingesteld 
om door middel van goed opgeleide werknemers het concurrentievermogen van Britse bedrijven te vergroten. De eerste verkennende studies naar de resultaten van de instelling van het IP-keurmerk stemmen positief: Werknemers lijken tevredener, bedrijfsresultaten zouden verbeterd zijn en organisaties met een IP-keurmerk hebben een positievere uitstraling naar potentiële werknemers toe.

In Nederland pleit het kabinet er in het actieprogramma 'Een leven lang leren' voor een employability keurmerk in te stellen. Recentelijk is er dan ook een pilot-project met een Investors in People-standaard van start gegaan. Mocht de pilot succesvol verlopen, dan zal er ook een Nederlandse variant van het IP-keurmerk worden geïntroduceerd.

\subsection{Fase 1: Actuele inzetbaarheid}

In fase 1 van het theoretisch model dat in dit rapport gebruikt wordt zal individuele employability worden opgevat als de gemiddelde actuele inzetbaarheid per bedrijfssector van individuele werknemers. Deze actuele inzetbaarheid is opgebouwd uit een tweetal aspecten: een bereidheidsaspect en een vermogensaspect. Het bereidheidsaspect heeft betrekking op de wil van werknemers om actie te ondernemen om aantrekkelijk te blijven voor de arbeidsmarkt. Het gaat hierbij om de bereidheid van werknemers om zich flexibel op te stellen, de bereidheid zich bij te scholen en de bereidheid in een andere functie of lokatie te gaan werken. Het vermogensaspect van employability heeft betrekking op de capaciteiten die werknemers hebben om aan hun 'aantrekkelijkheid' voor de arbeidsmarkt te werken. Hierbij gaat het om het vermogen zich breed in te zetten, het vermogen te leren en het vermogen van functie te veranderen. Het bereidheidsaspect zal worden gemeten aan de hand van gegevens over toekomstige wensen en intenties. Het vermogensaspect richt zich meer op de actuele situatie en de wijze waarop deze tot stand is gekomen. Vermogens zullen worden bepaald aan de hand van gegevens over de gerealiseerde mobiliteit, opleiding en inzetbaarheid.

Aan de hand van deze bereidheids- en vermogensaspecten kan worden bepaald wat de actuele employability van een werknemer is. Indicatoren voor deze actuele individuele employability zijn mobiliteitsbereidheid en -vermogen, opleidingsbereidheid en -vermogen en inzetbaarheidsbereidheid en -vermogen. Op basis van deze zes indicatoren wordt in fase 1 van het onderzoek de gemiddelde individuele employability van werknemers per bedrijfssector bepaald. De individuele employability wordt in dit rapport uitgedrukt in een 'M.O.I.'-score, die staat voor Mobiliteit, Opleiding en Inzetbaarheid, de drie indicatoren die centraal staan bij het bepalen van de individuele employability. Vervolgens wordt hieruit de gemiddelde employability van werknemers per sector bepaald. De methodologische verantwoording van de M.O.I. en het bepalen ervan vormen de onderwerpen van de hoofdstukken 2 en 3 van dit rapport. 


\subsection{Fase 2: Ontwikkelingen in de maatschappelijke context}

Naast de momentopname van de employability van de werknemers in een sector op basis van de M.O.I.-score wordt ook bepaald in hoeverre er binnen sectoren behoefte bestaat aan werknemers die potentieel employable zijn. Deze behoefteindicator meet de totale behoefte aan employability en is geen maatstaf voor het verschil tussen de behoefte en de aanwezige employability in een sector. Het bepalen van de employability behoefte zal gebeuren op basis van vier soorten ontwikkelingen die aanleiding geven een employability-beleid te voeren; technologische, organisatorische, economische en demografische ontwikkelingen (Van Vliet, 1997; ROA; 1998a). Naarmate deze ontwikkelingen een belangrijkere rol spelen binnen een sector is de behoefte aan werknemers met een goede employability groter.

In fase 2 van het onderzoek wordt geïnventariseerd in hoeverre er binnen de verschillende sectoren behoefte bestaat aan werknemers met een hoge employability. Dit gebeurt aan de hand van de intensiteit waarmee de vier besproken ontwikkelingen zich binnen de verschillende sectoren voordoen. De bepaling van de employabilitybehoefte krijgt haar beslag in hoofdstuk 4 .

\subsection{Fase 3: Confrontatie}

In de derde fase van het onderzoek wordt bepaald in hoeverre de aanwezige employability per sector (gemiddelde M.O.I. per sector) overeenkomt met de behoefte aan employability binnen de sector, op basis van de bovengenoemde maatschappelijke ontwikkelingen. Deze vergelijking geeft een indicatie van de eventuele verschillen tussen de aanwezige employability van de werknemers in een bepaalde sector en de behoefte aan employability in de desbetreffende sector. Op basis daarvan kan worden aangegeven in welke sectoren de grootste behoefte bestaat aan een verbetering van de employability van de werknemers. Deze confrontatiefase in de totstandkoming van de S.E.I. zal worden besproken in hoofdstuk 5.

\subsection{Fase 4: Effectueringscondities}

Fase 4 van het onderzoek bestaat uit een inventarisatie van de effectueringscondities zoals die binnen de verschillende sectoren bestaan. Deze effectueringscondities zijn in navolging van Thijssen (1997) op te vatten als de omstandigheden waaronder werknemers binnen een organisatie, branche of sector hun actuele inzetbaarheid kunnen effectueren.

Effectueringscondities kunnen zowel sector-gerelateerd (werkgelegenheid, uitwijkmogelijkheden binnen de sector) als organisatie-gerelateerd (scholingsinspanningen, aanwezigheid van mobiliteitscentra, aanwezigheid van interne uitzend- 
bureau's, roulatie-systemen en de 'employability-mindedness' van leidinggevenden) zijn.

Op basis van empirische gegevens met betrekking tot de inspanningen van organisaties gericht op de ontwikkeling van de employability van werknemers en de werkgelegenheidsontwikkelingen binnen sectoren wordt bepaald of er in een sector gunstige of minder gunstige effectueringscondities bestaan. De inventarisatie van de effectueringscondities vindt plaats in hoofdstuk 6 .

\subsection{Fase 5: Sectorale Employability Index (S.E.I.)}

In fase 5 van het onderzoek wordt de uiteindelijke Sectorale Employability Index samengesteld door de effectueringscondities te combineren met de confrontatie van de M.O.I. en de behoefte aan employability. Deze S.E.I. geeft aan binnen welke sectoren de behoefte aan employability het beste aansluit bij de aanwezige employability, waarbij ook rekening wordt gehouden met de in de desbetreffende sector aanwezige effectueringscondities. De sectoren waar de gemiddelde M.O.I. niet goed aansluit bij de employability behoefte en waar de effectueringscondities relatief slecht zijn, geldt, scoren slecht op de uiteindelijk index. De samenstelling van de S.E.I. komt in hoofdstuk 7 aan de orde.

Ten slotte zal nog worden gekeken naar de relatieve positie van een aantal specifieke doelgroepen in de diverse sectoren: vrouwen, jongeren, ouderen en laag opgeleiden. Hiervoor zal voor iedere doelgroep afzonderlijk een S.E.I. worden opgesteld. Deze doelgroep-specifieke S.E.I.'s geven aan in hoeverre er in de verschillende bedrijfssectoren ook aandacht wordt geschonken aan de employability van deze specifieke doelgroep. 


\section{Individuele employability}

\subsection{Inleiding}

In de eerste stap bij de totstandkoming van de S.E.I. zal worden gekeken naar de individuele employability van werknemers op een bepaald moment in de tijd. In hoofdstuk 1 is reeds aangegeven dat bij de bepaling van de individuele employability van werknemers een tweetal aspecten centraal staat: een bereidheidsaspect en een vermogensaspect.

Om deze aspecten van employability te kunnen meten, is een aantal indicatoren vereist. In dit hoofdstuk wordt de keuze voor bepaalde indicatoren verantwoord. Het hoofdstuk heeft een tweeledig karakter. Enerzijds wordt er een overzicht gegeven van mogelijke indicatoren voor employability zoals die in de literatuur naar voren komen. Anderzijds wordt er een zestal concrete indicatoren geselecteerd, die in de volgende hoofdstukken nader aan de orde zullen komen.

In paragraaf 2.2 wordt een overzicht gegeven van de concepten die in de literatuur naar voren komen als maatstaven voor employability. Er zal ingegaan worden op mobiliteitsbereidheid en -vermogen, opleidingsbereidheid en -vermogen en de bereidheid en het vermogen tot een brede inzetbaarheid. In paragraaf 2.3 is vervolgens aangegeven hoe deze concepten het beste kunnen worden vertaald naar zes concrete indicatoren voor individuele employability. Per indicator wordt aangegeven hoe deze het beste kan worden gemeten. In paragraaf 2.4 wordt daarna aangegeven welke data er zijn gebruikt bij de meting van de zes deelscores van employability. Paragraaf 2.5 geeft een samenvattend overzicht van het hoofdstuk en gaat kort in op de belangrijkste beperkingen van de beschikbare data.

\subsection{Indicatoren voor individuele employability}

Om een goed beeld te krijgen van wat de genoemde aspecten van employability precies inhouden, zal er eerst een overzicht gegeven worden van de concepten die in dit rapport naar voren gebracht zullen worden. Hierbij staat het belang van de afzonderlijke indicatoren voor de bepaling van de employability centraal.

\section{Mobiliteitsbereidheid en -vermogen}

Mobiliteitsbereidheid wordt in de literatuur vaak gedefinieerd als de bereidheid van werknemers van functie of van fysieke werklokatie te veranderen. Het gaat hierbij niet alleen om functieverandering binnen de organisatie (interne mobiliteit) maar ook om de bereidheid over te stappen naar een andere organisatie (externe mobiliteit). Volgens Gaspersz en Ott (1996) vergroot de mobiliteitsbereidheid de kansen op werk, omdat ze getuigt van een flexibele instelling. Tevens is de bereidheid tot 
mobiliteit van groot belang voor de ontwikkeling van werknemers. Door met enige regelmaat van functie of werklokatie te veranderen binnen of tussen organisaties maken werknemers zich immers een breed en gevarieerd ervaringenpakket eigen, waardoor het risico op zogenaamde 'ervaringsconcentratie' wordt geminimaliseerd. Dit houdt hen wend- en weerbaar op de arbeidsmarkt en dus employable.

Een andere factor die het belang van mobiliteitsbereidheid voor de kansen op de arbeidsmarkt aangeeft is het gegeven dat organisaties over het algemeen op zoek zijn naar werknemers met een flexibele instelling, om met de steeds snellere en meer ingrijpende veranderingen in hun omgeving om te kunnen gaan.

Mobiliteitsbereidheid van werknemers kan voor organisaties die personeel willen werven een teken zijn dat een werknemer de gewenste flexibele (mobiliteitsbereide) instelling heeft waarnaar zij op zoek zijn. De kansen op werk voor deze werknemers nemen dus toe, wat weer een positief effect heeft op hun employability.

Wanneer een werknemer te kennen geeft graag eens op een andere lokatie of in een andere functie te willen werken getuigt dat, ongeacht de reden daarvoor, van een mobiliteitsbereide instelling. Is de werknemer echter niet in voldoende mate gekwalificeerd voor werk op andere lokaties of in andere functies, dan zal de mobiliteitsbereidheid zich niet manifesteren, omdat het de werknemer aan mobiliteitsvermogen ontbreekt. Het mobiliteitsvermogen is dus eveneens een belangrijke indicator voor employability.

\section{Opleidingsbereidheid en -vermogen}

Bolhuis (1995) onderscheidt drie aspecten die de opleidingsbereidheid en het opleidingsvermogen bepalen: leerhouding, leervaardigheden en leerinhoud. Eerst zal worden ingegaan op de leerhouding (opleidingsbereidheid), daarna komen de leervaardigheden en de leerinhoud (opleidingsvermogen) aan de orde.

Opleidingsbereidheid wordt hier gedefinieerd als de bereidheid van werknemers om tijd en energie te steken in hun opleiding en ontwikkeling ter bevordering van de eigen inzetbaarheid (Bolweg en Van Beckhoven, 1995). De bereidheid te investeren in het eigen menselijk kapitaal vormt een essentieel onderdeel van de individuele employability. Gaspersz en Ott (1996) stellen zelfs dat de inzetbaarheid van de aanwezige kennis en vaardigheden binnen of buiten de bedrijfstak geldt als de belangrijkste graadmeter voor employability. Of werknemers bereid zijn te investeren in hun eigen menselijk kapitaal zal voor een groot deel afhankelijk zijn van het rendement van een dergelijke investering. Het rendement kan bestaan uit een verbeterde arbeidsmarktpositie. De beste arbeidsmarktposities worden ingenomen door hooggekwalificeerden, omdat werkgevers veronderstellen dat de productiviteit van werknemers positief samenhangt met hun opleidingsniveau (Wolbers, 1998). Werk- 
nemers die zich niet of nauwelijks verder ontwikkelen maken zich dus tot een minder aantrekkelijke partij voor de werkgever. Bereidheid tot het volgen van opleidingen vormt dus een belangrijk onderdeel van de employability van werknemers.

Het feit dat werknemers zich bereid verklaren opleidingen en cursussen te volgen is op zich niet voldoende voor een goede employability. Wanneer een werknemer immers niet het vermogen heeft om een bepaalde opleiding af te ronden heeft de opleidingsbereide instelling weinig waarde. Het vermogen opleidingen te volgen is van een aantal factoren afhankelijk. Allereerst speelt de initiële opleiding een rol. Een hogere vooropleiding stelt werknemers doorgaans in staat zich gemakkelijker verder te ontplooien. Dit verklaart ook de hoge scholingsparticipatie van hoger opgeleiden (zie bv ROA, 1998a/b).

Volgens Bolhuis (1995) zijn vooral de leervaardigheden en de leerinhoud van belang voor het opleidingsvermogen. Hij onderscheidt zes deelvaardigheden die van belang zijn bij het opdoen van leervaardigheden:

- Sociale vaardigheden.

- Leren door ervaring en door doen.

- Leren door reflectie.

- Verwerken van abstracte informatie.

- Taal- en symboolgebruik.

- Reguleren van het leerproces.

Niet alleen de leervaardigheden, maar ook de leerinhoud is van belang voor de opleidingsbereidheid. Leerinhoud heeft betrekking op de aanwezige intelligentie en basiskennis. Leerinhoud is onder te verdelen in drie elementen:

- Kennis die een individu op bepaalde terreinen heeft verworven; de basiskennis, opgedaan tijdens het initieel onderwijs.

- Kennis en opvattingen van een individu over leren, inclusief eventuele metacognitieve kennis (kennis over het vergaren van kennis).

- Kennis en opvattingen die een individu koestert over het eigen leervermogen in het algemeen en op bepaalde specifieke terreinen.

De basiskennis is van belang voor het leervermogen omdat de basiskennis mensen in staat stelt iets nieuws te leren. Het gaat hierbij bijvoorbeeld om kennis die een persoon op een bepaald terrein reeds heeft verworven. Is de basiskennis op een bepaald terrein vrij uitgebreid, dan is het aanleren van nieuwe vaardigheden op dat terrein eenvoudiger. Deze basiskennis kan bijvoorbeeld betrekking hebben op een op een bepaald terrein gebruikt begrippenkader c.q. vakjargon. Ook de kennis die iemand heeft over manieren om kennis te vergaren kan bijdragen tot diens 
vermogen tot leren. Het weten waar bepaalde informatie gevonden kan worden vergemakkelijkt kennisverwerving op latere tijdstippen.

De opvattingen en kennis omtrent het eigen leervermogen spelen een belangrijke psychologische rol voor het opleidingsvermogen van individuen. Wanneer werknemers hun eigen vermogen om iets te leren gering achten dan zal het vermogen iets te leren daar niet bij gebaat zijn. Voldoende geloof in het eigen kunnen zet mensen er eerder toe aan daadwerkelijk leeractiviteiten te ontplooien.

\section{Bereidheid en vermogen tot brede inzetbaarheid}

De bereidheid tot brede inzetbaarheid is op te vatten als de wil van werknemers om indien nodig werkzaamheden of taken te verrichten in verschillende functies. Deze vorm van inzetbaarheid noemen Bolweg en Maenhout (1995) de kwalitatieve inzetbaarheid. Hierbij kan het gaan om het tijdelijk op zich nemen van taken van een collega of het tijdelijk werken op een andere afdeling. Het verrichten van werkzaamheden die tot een andere functie behoren geeft werknemers een brede ervaringsopbouw, waardoor hun algehele inzetbaarheid en daarmee hun employability verbetert. De bereidheid van werknemers om zich breed in te zetten maakt hen tot een aantrekkelijke partij voor werkgevers en bevordert dus de kansen op de arbeidsmarkt.

Naast de kwalitatieve inzetbaarheid wordt in de literatuur ook de kwantitatieve inzetbaarheid van werknemers onderscheiden (Bolweg en Van Beckhoven, 1994; Bolweg en Maenhout, 1995; Singerling en Mes, 1995). Bij kwantitatieve inzetbaarheid gaat het met name om de werktijden. De bereidheid op wisselende tijden te werken of over te werken is ook een belangrijke indicator voor de employability van werknemers.

De bereidheid zich kwalitatief en kwantitatief breed in te zetten voegt echter niet veel toe aan de employability van werknemers als deze bereidheid niet gepaard gaat met het daadwerkelijk vermogen zich breed in te zetten. Het vermogen om breed inzetbaar te zijn, heeft betrekking op de capaciteiten die een werknemer bezit om taken van anderen op zich te nemen, overuren te maken of op wisselende tijden te werken. Op dit punt zijn niet alleen de cognitieve capaciteiten van werknemers van belang maar ook hun lichamelijke conditie. Het kan immers zo zijn dat een werknemer vanwege bepaalde lichamelijke klachten niet in staat is specifieke taken van anderen over te nemen. Dit heeft een negatieve invloed op de inzetbaarheid van de werknemer. 


\subsection{Operationalisatie van de concepten}

In deze paragraaf zal worden aangegeven op basis van welke feitelijke indicatoren de individuele employability van werknemers kan worden geïndiceerd. Er zal worden ingegaan op de zes in paragraaf 2.2 beschreven aspecten van employability. Van elke indicator zal kort worden aangegeven hoe zij het beste kan worden gemeten.

\section{Mobiliteitsbereidheid}

Mobiliteitsbereidheid kan het beste worden gemeten door gebruik te maken van gegevens over de wens van werknemers om op korte termijn van baan of werklokatie te veranderen. Om hier enig inzicht in te krijgen kan het beste worden gekeken naar het feitelijke zoekgedrag van werknemers. Indien een werknemer met enige regelmaat solliciteert of anderszins uiting geeft aan mobiliteitswensen dan is de mobiliteitsbereidheid van deze werknemers groot.

Bij het bepalen van mobiliteitsbereidheid op basis van gegevens omtrent het zoekgedrag van werknemers, dient overigens wel een onderscheid te worden gemaakt naar zoekgedrag op initiatief van de werknemers zelf en zoekgedrag dat door exogene factoren wordt opgelegd. Wanneer het zoekgedrag van werknemers bijvoorbeeld voortkomt uit de wens hogerop te komen of meer te verdienen, dan is er sprake van mobiliteitsbereidheid op initiatief van de werknemer. Is er sprake van mobiliteitsbereidheid doordat werknemers vrezen of zelfs zeker weten dat hun baan gaat verdwijnen, of doordat veranderingen in de thuissituatie ertoe dwingen van functie te veranderen, dan is er weliswaar sprake van mobiliteitsbereidheid maar niet in die zin dat het de individuele employability indiceert. Het zoekgedrag waartoe werknemers worden gedwongen kan niet worden beschouwd als een vorm van mobiliteitsbereidheid en mag dan ook niet als indicator gelden.

Naast het zoekgedrag van werknemers naar een andere baan is ook de bereidheid te verhuizen voor het werk een indicator voor iemands mobiliteitsbereidheid. In de literatuur spreekt men dan van geografische mobiliteit (Bolweg en Van Beckhoven, 1995; Singerling en Mes, 1994; Van Geuns en Platje, 1994 en Bolweg en Maenhout, 1995). Om deze mobiliteitsbereidheid te bepalen kan het beste worden gevraagd naar de bereidheid van werknemers om te verhuizen indien de werkgever daarom verzoekt. Hierbij dient een onderscheid te worden gemaakt naar de verhuisbereidheid binnen de regio en naar plaatsen daarbuiten. Bovendien is het belangrijk een onderscheid te maken tussen verhuizingen vanwege functieverandering op gelijk niveau en verhuizingen vanwege promotie naar een hoger functieniveau. Wanneer werknemers bereid zijn overal naartoe te verhuizen, ook al gaan zij er niet op vooruit qua functieniveau, dan is hun geografische mobiliteitsbereidheid het grootst. 


\section{Mobiliteitsvermogen}

De tweede indicator die voor de bepaling van de individuele employability van belang is, is het mobiliteitsvermogen van werknemers. Het mobiliteitsvermogen is afhankelijk van een aantal factoren. Allereerst speelt het arbeidsverleden van werknemers een rol. Werknemers die verschillende keren van functie zijn veranderd doen op dit terrein bepaalde vaardigheden op en bevorderen op die manier hun mobiliteitsvermogen.

Naast het arbeidsverleden kan ook de sociale geworteldheid van werknemers van invloed zijn op hun mobiliteitsvermogen. Een werknemer die schoolgaande kinderen, een werkende partner of bepaalde nevenactiviteiten heeft, zal minder snel van functie en met name werklokatie kunnen veranderen. Het effect van het hebben van een werkende partner op de mobiliteit is echter ambigu (Kruidenier en Manchia, 1998). Aan de ene kant geeft de baan van de partner extra inkomenszekerheid, waardoor meer risico genomen kan worden, waardoor men eerder van functie of werklokatie zou kunnen veranderen. Anderzijds zorgt het werk van de partner vaak voor extra binding met de woonomgeving, waardoor functieverandering of verandering van werklokatie moeilijker wordt.

Ook het aantal en de aard van de gevolgde opleidingen en cursussen speelt een rol bij de opbouw van iemands mobiliteitsvermogen. Is een werknemer laag geschoold of is diens gehele scholingstraject specifiek gericht op de huidige functie, dan zijn de mogelijkheden tot mobiliteit doorgaans gering en is het mobiliteitsvermogen derhalve niet groot.

Ten slotte speelt de verblijfstijd van werknemers in hun huidige functie een rol. Wanneer werknemers lange tijd dezelfde functie binnen dezelfde organisatie vervullen dan kan dit schadelijk zijn voor hun mobiliteitsvermogen. Werknemers lopen hierdoor immers een verhoogd risico op wat wel wordt aangeduid als 'ervaringsconcentratie' (Thijssen, 1996). Hun vaardigheden en kennis zijn dan vaak niet goed meer bruikbaar in andere functies, waardoor hun mobiliteitsvermogen beperkt is.

Zoals reeds is aangegeven wordt het vermogen tot mobiliteit hoofdzakelijk bepaald door de feitelijke mobiliteit in het recente verleden. Is een werknemer op velerlei terreinen en plaatsen werkzaam geweest dan is het mobiliteitsvermogen groot. Het mobiliteitsvermogen kan derhalve het beste gemeten worden door het mobiliteitsgedrag in het recente verleden. Om tot een betrouwbare inschatting te komen van het mobiliteitsvermogen zou allereerst gekeken moeten worden naar de verblijfsduren van werknemers in dezelfde functie bij dezelfde werkgever. Omdat de leeftijd van werknemers voor de verblijfsduur in hun huidige functie een grote rol speelt, zou ook het aantal jaren dat een werknemer in totaal actief is op de arbeidsmarkt en de leeftijd van de werknemers in de analyse betrokken moeten worden. Een werknemer 
die pas enkele jaren actief is op de arbeidsmarkt heeft immers weliswaar een relatief korte verblijfsduur in dezelfde functie bij dezelfde werkgever, maar hoeft daarom nog geen groot mobiliteitsvermogen te hebben. In feite zou op dit punt een meer complexe indicator wenselijk zijn op basis van een zgn. duuranalyse, waarbij rekening gehouden wordt met de onvoltooide duren (zie bv. Kalbfleisch en Prentice, 1980). Naast de verblijfsduur in de huidige functie kan worden gekeken naar de functieveranderingen van werknemers. Hierbij speelt de reden voor de veranderingen van baan geen rol. Immers, iedere ervaring die men opdoet met mobiliteit zal in zekere zin het mobiliteitsvermogen doen toenemen.

\section{Opleidingsbereidheid}

Of werknemers de wil hebben zich verder te laten scholen hangt van een aantal zaken af. Een eerste factor die van invloed zou kunnen zijn is de ervaring met eerdere leeractiviteiten. Heeft een werknemer van jongs af aan slechte ervaringen in het onderwijs, dan is de bereidheid tot het volgen van cursussen e.d. waarschijnlijk niet groot.

Een andere factor die van invloed is, betreft de inschatting van het eigen opleidingsvermogen. Wanneer een werknemer de overtuiging heeft niet in staat te zijn een opleiding of cursus met succes af te ronden zal diens wil om met de opleiding te beginnen gering zijn. Het vertrouwen in het eigen kunnen speelt dus eveneens een belangrijke rol. Om de opleidingsbereidheid van werknemers te bepalen zijn derhalve gegevens nodig die betrekking hebben op de wensen die de werknemers zelf hebben ten aanzien van hun verdere scholing.

Ten derde zou aan de hand van investeringen van werknemers in hun eigen menselijk kapitaal kunnen worden bepaald in hoeverre zij bereid zijn opleidingen te volgen. Werknemers die weinig tot niets investeren in de eigen scholing en ontwikkeling zijn minder opleidingsbereid dan de werknemers die bereid zijn de kosten van scholing geheel of gedeeltelijk zelf te dragen. Hierbij dient overigens wel een onderscheid gemaakt te worden tussen generieke opleidingen en bedrijfsspecifieke opleidingen. Volgt een werknemer immers met name bedrijfsspecifieke cursussen dan zal dit wellicht eerder kunnen leiden tot een inperking van de latere mogelijkheden op de arbeidsmarkt. Een investering in meer generieke opleidingen is derhalve met het oog op de employability van de werknemer verstandiger.

Ten slotte zijn ook financiële en tijdsaspecten van belang. Werknemers zullen in het algemeen meer bereid zijn tot het volgen van opleidingen wanneer het bedrijf daarvoor tijd beschikbaar stelt en/of de opleiding betaalt 


\section{Opleidingsvermogen}

Een opleidingsbereide instelling heeft echter weinig waarde, wanneer een werknemer niet beschikt over de capaciteiten om de relevante opleidingen te volgen. Het vermogen van werknemers om opleidingen te volgen wordt allereerst bepaald aan de hand van de hoogst genoten initiële opleiding van werknemers. De initiële opleiding geeft immers de basiskennis aan, waarop werknemers voortbouwen. Is deze opleiding van een hoger niveau (HBO of WO) dan duidt dat op een grote mate van wat Bolhuis (1995) 'basiskennis' noemt. Deze grotere basiskennis geeft de werknemer meer mogelijkheden op de arbeidsmarkt. Onderwijs is immers ook als een positioneel goed te beschouwen (Hirsch, 1977; Ultee, 1978). Een hoge vooropleiding impliceert ook een grote mate van meta-cognitieve kennis, de kennis van het leren, waardoor een werknemer gerichter opleidingen zal kunnen volgen.

Het opleidingsvermogen van werknemers kan daarnaast nog worden bepaald aan de hand van gegevens over de gevolgde aanvullende opleidingen en cursussen. Met name de opleidingen die met een diploma of getuigschrift zijn afgerond en het aantal opleidingen dat met succes is gevolgd geven een goed beeld van het opleidingsvermogen van werknemers. Ook het verschil tussen de feitelijke en de nominale duur van de opleidingen kan daarbij een belangrijke rol spelen. Naarmate een werknemer er langer over doet zich bepaalde stof eigen te maken, is diens leervermogen doorgaans geringer. Dat laatste geldt echter alleen als er geen andere factoren een rol spelen bij de studievertraging. Ziekte kan bijvoorbeeld tot een behoorlijke vertraging leiden, zonder dat er echt sprake is van een gering opleidingsvermogen. Voorzichtigheid bij de analyse van dergelijke gegevens is dus geboden.

\section{Bereidheid tot brede inzetbaarheid}

De bereidheid tot een brede inzetbaarheid kan goed worden bepaald aan de hand van gegevens over de wil van werknemers om werkzaamheden te verrichten die eigenlijk niet tot het eigen functiegebied behoren. Daarnaast speelt de bereidheid van werknemers om zich ook qua werktijden flexibel op te stellen een rol. Daarbij zou wel gecorrigeerd moeten worden voor de arbeidsmarktpositie die de werknemer heeft. Het is bijvoorbeeld immers mogelijk dat werknemers met een deeltijdsaanstelling vaker bereid zijn overwerk te verrichten dan werknemers met een voltijdsaanstelling.

\section{Vermogen tot brede inzetbaarheid}

Het vermogen tot brede inzetbaarheid kan worden bepaald aan de hand van informatie over de aangetoonde inzetbaarheid. Daarbij kan worden gekeken naar de werktijd waarin werknemers daadwerkelijk werkzaam zijn geweest op een ander gebied dan dat van de eigen functie. Deze gegevens geven dan een indicatie van 
de ervaring die een werknemer heeft met het veranderen van werkomgeving. Dit geeft het gemak aan waarmee een werknemer andere werkzaamheden zou kunnen verrichten. Daarbij geeft het verrichten van taken buiten het eigen functiegebied werknemers ook een breed ervaringenpakket, waardoor de mogelijkheden elders taken te verrichten worden vergroot.

Naast het arbeidsverleden speelt ook het opleidingsverleden van werknemers een rol. Met name de aard van de gevolgde opleidingen vormt een belangrijke graadmeter bij de bepaling van de mogelijkheden die een werknemer heeft zich breed in te zetten. Wanneer werknemers veel verschillende cursussen hebben gevolgd, dan zijn zij waarschijnlijk in staat zich op veel verschillende plaatsen in een organisatie in te zetten. Overigens is het wel van belang dat de ervaring die met andere werkzaamheden wordt opgedaan een zekere relatie heeft met het eigen functiegebied, zodat het verwerken van nieuwe kennis niet te moeilijk wordt en daardoor tot frustraties leidt. Bij het bepalen van het opleidingsverleden moet tenslotte nog een onderscheid worden gemaakt naar specifieke en generieke scholing. Zoals reeds eerder is opgemerkt kan specifieke scholing immers op den duur leiden tot ervaringsconcentratie, waardoor de inzetbaarheid van werknemers afneemt. Volgt een werknemer alleen scholing die gericht is op de eigen functie, dan is dit niet bevorderlijk voor het vermogen om breed te kunnen worden ingezet.

Naast een indicatie van het vermogen van werknemers om op andere functiegebieden of werklokaties te werken dient ook een indicatie te worden gegeven van het vermogen op wisselende tijden te werken. Hierbij kan allereerst gekeken worden naar fysieke aspecten. Fysieke slijtage bij werknemers kan ertoe leiden dat zij lichamelijk niet meer in staat zijn zich breed in te zetten, doordat bepaalde werkzaamheden gewoonweg te veel eisen. Het vermogen zich breed in te zetten neemt af voor werknemers die te maken hebben met fysieke slijtage (Bakker en Van der Heijden, 1997). Dit laatste effect geldt zowel voor de kwalitatieve als kwantitatieve inzetbaarheid. Het vermogen zich op wisselende tijden in te zetten neemt overigens af met de leeftijd, omdat het naarmate men ouder wordt steeds moeilijker wordt zich te herstellen na inspanningen. Dit leidt ertoe dat het met name voor oudere werknemers steeds moeilijker wordt om bijvoorbeeld in ploegendienst te werken (Thierry, 1977).

\subsection{Gebruikte databronnen voor de M.O.I.}

In deze paragraaf zal worden aangegeven welke gegevens zijn gebruikt om tot een inschatting van de individuele employability van werknemers te komen. Per indicator zullen de vragen waarop de desbetreffende indicator is gebaseerd kort worden weergegeven, waarna een korte argumentatie volgt van de reden om juist deze vraag in de analyse te betrekken. De gebruikte gegevens zijn afkomstig uit het OSAarbeidsaanbodsurvey uit 1996. Uitgangspunt daarbij is dat indicatoren gepresen- 
teerd worden op het laagst mogelijke aggregatieniveau waarbij betrouwbaarheid en volledigheid nog gewaarborgd zijn.

\section{Mobiliteitsbereidheid}

Om inzicht te krijgen in de mobiliteitsbereidheid van werknemers is gebruik gemaakt van een aantal vragen uit het OSA-arbeidsaanbodsurvey 1996. De vragen hebben betrekking op het huidige zoekgedrag van werknemers en het zoekgedrag in de 12 maanden voorafgaand aan de enquête. In het eerste geval is gevraagd of men momenteel actief op zoek is naar een andere baan, waarbij expliciet wordt vermeld dat het dient te gaan om een andere hoofdbaan en niet om een bijbaan. In het tweede geval is aan respondenten gevraagd of zij in de afgelopen 12 maanden weleens actief naar een andere baan hebben gezocht. Op beide vragen kon met ja of nee worden geantwoord.

Om inzicht te krijgen in de achterliggende oorzaken van het zoekgedrag is voorts aan degenen die hebben gezocht of zoeken naar een andere baan gevraagd naar de reden daarvoor. Op deze vraag waren 10 antwoorden mogelijk: meer salaris, beter vooruitkomen, huidige werk bevalt niet, zoals reeds eerder is aangegeven het zeker kwijt raken van het huidige werk, bang dat het huidige werk verloren gaat, meer zekerheid, veranderende omstandigheden thuis, inkomensdaling in het huishouden, anders en weet niet. De achterliggende oorzaken van het zoekgedrag spelen, zoals reeds eerder is aangegeven, een belangrijke rol. Een andere baan zoeken omdat de huidige baan op korte termijn zal verdwijnen zegt immers minder over iemands mobiliteitsbereidheid dan het zoeken naar een andere baan omdat de huidige baan geen doorgroeimogelijkheden meer biedt. Met de achterliggende oorzaken van uitingen van mobiliteitsbereidheid zal dus zeker rekening moeten worden gehouden bij de bepaling van iemands mobiliteitsbereidheid.

\section{Mobiliteitsvermogen}

Het mobiliteitsvermogen zal evenals de mobiliteitsbereidheid worden bepaald aan de hand van gegevens uit het OSA-arbeidsaanbodsurvey 1996. Zoals reeds bleek is het voor de bepaling van het mobiliteitsvermogen allereerst van belang te kijken naar de verblijfsduur in de huidige functie.

Om deze verblijfsduur te bepalen is gevraagd naar de maand en het jaar van indiensttreding bij de huidige werkgever in de huidige functie. Omdat alleen op basis van deze gegevens geen conclusies kunnen worden getrokken omtrent het mobiliteitsvermogen is naast de verblijfsduur bij de huidige werkgever in de huidige functie ook de verblijfsduur op de arbeidsmarkt als geheel gevraagd. De verhouding tussen de totale verblijfsduur op de arbeidsmarkt en de verblijfsduur in de huidige functie verschaft al een beter inzicht in het mobiliteitsvermogen. In deze analyse wordt ook 
de leeftijd van de werknemer betrokken. Naarmate werknemers ouder zijn en relatief langer dezelfde functie bij dezelfde werkgever uitoefenen, hebben zij een geringer mobiliteitsvermogen.

\section{Opleidingsbereidheid}

Inzicht in de bereidheid van werknemers om zich te laten opleiden wordt verkregen door te kijken naar de mate waarin er door werknemers daadwerkelijk opleidingen worden gevolgd. Idealiter zou daarbij een onderscheid gemaakt moeten worden tussen investeringen in opleidingen die gedeeltelijk door de werknemers zelf betaald worden en de scholing die door het bedrijf gefinancierd wordt. Dit bleek echter met de gebruikte databron, het OSA-arbeidsaanbodsurvey 1996, niet goed mogelijk. Bij het bepalen van de opleidingsbereidheid van een werknemer is de feitelijke scholingsparticipatie als uitgangspunt genomen. Of iemand opleidingen ook daadwerkelijk afrondt is voor de opleidingsbereidheid strikt genomen van ondergeschikt belang en zal dan ook vanuit deze invalshoek niet in de analyse worden meegenomen.

\section{Opleidingsvermogen}

Aan de basis van iemands opleidingsvermogen staat de initiële opleidingsachtergrond. Allereerst zal dus de initiële opleiding van werknemers gebruikt worden om hun opleidingsvermogen in te schatten. Des te hoger de initiële opleiding des te hoger het opleidingsvermogen. Naast de vooropleiding geven ook de gevolgde aanvullende opleidingen en cursussen tijdens de loopbaan een belangrijke indicatie van iemands opleidingsvermogen. Waar het succesvol afronden van een opleiding of cursus bij de bepaling van de opleidingsbereidheid niet van belang is, is het diploma of het certificaat voor de bepaling van het opleidingsvermogen vanzelfsprekend wel van belang. Het behalen van het diploma geeft immers aan dat een werknemer in staat is gebleken de desbetreffende opleiding met succes af te ronden. Om het uiteindelijke opleidingsvermogen van werknemers te bepalen is hun initiële opleiding gecombineerd met de met een diploma of certificaat afgesloten cursussen. Uitgangspunt bij het bepalen van het opleidingsvermogen is dan het totaal aantal jaren dat een werknemer in opleiding is geweest.

\section{Bereidheid tot brede inzetbaarheid}

Om de bereidheid tot brede inzetbaarheid voor wat betreft de te verrichten taken te meten is gebruik gemaakt van de vraag of werkenden bereid zijn zich, als dat bij het bedrijf waar zij werken zo uitkomt, in te zetten voor werkzaamheden die eigenlijk tot een andere functie behoren. 


\section{Vermogen tot brede inzetbaarheid}

Ten slotte zal het vermogen om breed te worden ingezet worden geïndiceerd aan de hand van gegevens over de verschillende werkzaamheden die een werknemer verricht. Uitgangspunt hierbij is de vraag in het OSA-arbeidsaanbodsurvey 1996 die betrekking heeft op de frequentie waarmee werknemers werkzaamheden verrichten die eigenlijk niet tot de eigen functie behoren. Hierbij geldt tevens dat het gaat om situaties waarin het verzoek om een brede inzet van de kant van de organisatie komt.

Bij deze vraag was een viertal antwoorden mogelijk met betrekking tot de gevraagde frequentie: vaak, niet zo vaak, een enkele keer, nooit. Hoe vaker men zich inzet op andere afdelingen voor andere werkzaamheden des te groter is het vermogen tot een brede inzetbaarheid.

\subsection{Samenvatting en conclusie}

In dit hoofdstuk zijn zes indicatoren, die gebruikt kunnen worden om de individuele employability van werkgevers in beeld te brengen, de revue gepasseerd. Een overzicht van de gebruikte concepten, de operationalisaties en de uiteindelijke indicatoren wordt gegeven in tabel 2.1. De tabel geeft aan dat niet elk aspect van de individuele employability van werknemers in dit rapport op basis van de gepresenteerde definities en operationalisaties ingeschat kan worden, vanwege het ontbreken van geschikte data. Er zijn echter voor elk van de zes employability-aspecten voldoende mogelijkheden om tot een betrouwbare inschatting te komen.

Bij de bepaling van de mobiliteitsbereidheid van werknemers kunnen bijvoorbeeld geen gegevens omtrent geografische mobiliteit worden gebruikt. Bij het indiceren van de mobiliteitsbereidheid van werknemers is derhalve alleen rekening gehouden met het zoekgedrag naar ander werk.

Voor wat betreft het mobiliteitsvermogen is de sociale geworteldheid van werknemers niet als invloedsfactor meegenomen. De beschikbare databronnen staan het gebruik van dergelijke gegevens niet of erg moeilijk toe. Overigens mag worden aangenomen dat de eventuele beperkende invloed van de sociale gewortelheid van werknemers op hun mobiliteitsvermogen doorgaans wordt weerspiegeld in de verblijfsduur in hun huidige functie, op basis waarvan het mobiliteitsvermogen hier is geïndiceerd.

Bij het meten van de opleidingsbereidheid is het moeilijk een onderscheid te maken tussen de investeringen in opleidingen die door werknemers zelf gefinancierd worden en de scholingsuitgaven die door bedrijven gedragen worden. Op basis van de 
gebruikte data is er ook geen analyse mogelijk van de eventuele slechte ervaringen die werknemers hebben in het onderwijs.

Het opleidingsvermogen kan wel bepaald worden volgens de in paragraaf 2.3 beschreven meetmethode. Aan de hand van gegevens over gevolgde (voor) opleidingen en cursussen kan een goede inschatting van het opleidingsvermogen verkregen worden.

Ook de bereidheid tot brede inzetbaarheid kan op basis van de beschikbare data direct worden gemeten. Hierbij wordt echter geen rekening gehouden met de mate waarin men flexibel is op het punt van de werktijden.

Het vermogen tot brede inzetbaarheid kan daarentegen slechts met de nodige beperkingen worden bepaald. Idealiter zou een onderscheid gemaakt moeten worden naar generieke en bedrijfspecifieke opleidingen. Dit bleek met de beschikbare data niet goed mogelijk.

In het algemeen geldt dat de vermogensaspecten van de individuele employability een niet-perfecte inschatting zijn van de potentiële employability van werknemers. Er wordt hier telkens gebruik gemaakt van gegevens die gerealiseerd gedrag belichten. Echter, verwacht mag worden dat deze gegevens een redelijk betrouwbare inschatting zijn van de potentiële employability-vermogens van werknemers. 


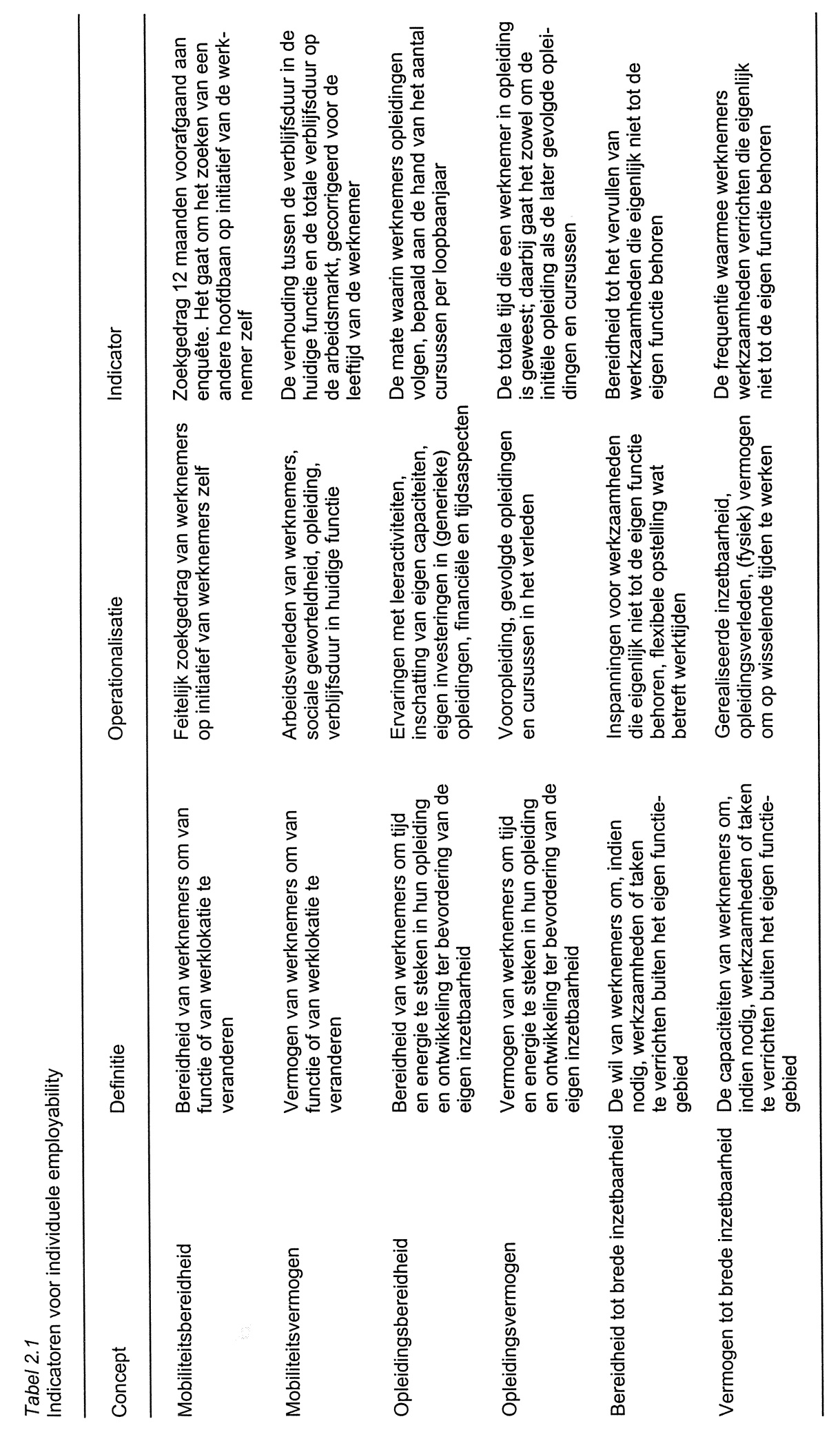




\section{Individuele employability per bedrijfssector}

\subsection{Inleiding}

In dit hoofdstuk worden de bedrijfssectoren gekarakteriseerd naar de mate van employability van de werknemers. Zoals al in hoofdstuk 1 naar voren kwam, vormt dit de eerste stap in het bepalen van de Sectorale Employability Index (S.E.I.). In het vorige hoofdstuk is verantwoord welke indicatoren gebruikt zouden kunnen worden om de individuele employability van werknemers te meten. In dit hoofdstuk worden de in hoofdstuk 2 genoemde indicatoren concreet ingevuld en gecombineerd tot één overkoepelende M.O.I.-indicator. Drie van de zes indicatoren meten een bereidheidsaspect van werknemers, de overige drie indicatoren een vermogensaspect. $\mathrm{Er}$ worden scores op de indicatoren en een M.O.I. berekend voor de totale groep werknemers in elke sector en voor de onderscheiden doelgroepen: vrouwen, jongeren, ouderen en laag-opgeleiden. Jongeren zijn werknemers in de leeftijd van 16 tot en met 29 jaar, terwijl onder ouderen werknemers van 50 tot en met 64 jaar worden verstaan. Laag opgeleiden zijn de werknemers met een initiële opleiding op een niveau lager dan MBO.

De verdere opzet van het hoofdstuk is als volgt. Eerst komen in paragraaf 3.2 de mobiliteitsbereidheid en het mobiliteitsvermogen aan de orde. Daarna wordt er in paragraaf 3.3 gekeken naar de opleidingsbereidheid en het opleidingsvermogen van de werknemers in de diverse sectoren. In paragraaf 3.4 zal vervolgens worden ingegaan op de bereidheid en het vermogen van werknemers om zich breed in te zetten. In paragraaf 3.5 worden de in dit hoofdstuk behandelde indicatoren gecombineerd tot één overkoepelende M.O.I.-indicator, die het vertrekpunt vormt voor de in de volgende hoofdstukken verder uit te werken S.E.I.

\subsection{Mobiliteitsbereidheid en -vermogen}

\section{Mobiliteitsbereidheid}

Mobiliteitsbereidheid wordt gemeten aan de hand van het zoekgedrag van werknemers. In tabel 3.1 wordt een overzicht gegeven van het percentage werknemers dat op eigen initiatief op zoek is of in de twaalf maanden voorafgaand aan de enquête op zoek is geweest naar een andere baan. Daarbij is zowel naar de mobiliteitsbereidheid voor alle werknemers als naar het zoekgedrag van de doelgroepen die in dit rapport worden onderscheiden gekeken.

Als naar de cijfers voor de mobiliteitsbereidheid wordt gekeken, zijn er een aantal opvallende uitkomsten. Allereerst blijkt dat ruim $10 \%$ van de werknemers op eigen initiatief op zoek is of recentelijk heeft gezocht naar een andere baan. Tussen vrouwelijke en mannelijke werknemers bestaan op dit punt weinig verschillen. Wel 
zijn er grote verschillen tussen ouderen en jongeren. Ruim $18 \%$ van de werkzame jongeren (16-29 jarigen) is op eigen initiatief op zoek naar een andere baan, terwijl dat percentage voor oudere werknemers (50-64 jarigen) slechts $0,8 \%$ bedraagt. Verder zijn laag opgeleide werknemers minder mobiliteitsbereid dan middelbaar en hoger opgeleiden.

Tabel 3.1

Mobiliteitsbereidheid per bedrijfssector, 1996

\begin{tabular}{lrrrrr}
\hline Bedrijfssector & totaal & vrouwen & jongeren & $\begin{array}{r}\text { ouderen } \\
\text { opgeleiden } \\
\%\end{array}$ \\
& $\%$ & $\%$ & $\%$ & $\%$ & $\begin{array}{r}\text { laag } \\
\text { Landbouw en visserij }\end{array}$ \\
Voeding & 2,5 & & 6,7 & & 4,0 \\
Chemie & 16,4 & 21,1 & 36,4 & 14,3 & 5,7 \\
Metaal en elektrotechniek & 11,1 & 25,0 & 26,3 & 0,0 & 7,1 \\
Overige industrie & 10,5 & 13,9 & 17,5 & 2,9 & 8,3 \\
Energie & 10,3 & 3,8 & 23,5 & 0,0 & 5,6 \\
Bouw en onroerend goed & 6,3 & 9,5 & 13,0 & 0,0 & 6,0 \\
Handel & 9,7 & 13,6 & 23,5 & 0,0 & 12,9 \\
Transport en communicatie & 13,8 & 2,3 & 7,7 & 0,0 & 7,9 \\
Bank- en verzekeringswezen & 6,4 & 6,0 & 15,6 & 0,0 & 0,0 \\
Horeca, reparatie en zakelijke & 6,1 & 14,0 & \\
dienstverlening & 14,1 & 17,2 & 20,9 & 0,0 & 10,7 \\
Kwartaire diensten & 9,8 & 8,3 & 16,1 & 1,1 & 8,7 \\
Overheid en onderwijs & 7,1 & 5,8 & 15,5 & 0,8 & 7,5 \\
Total & 10,3 & 10,1 & 18,7 & 0,8 & 8,6 \\
\hline
\end{tabular}

Bron: OSA/ROA

Tussen de sectoren blijken er vrij grote verschillen te bestaan in de mobiliteitsbereidheid van het personeel. De sector waar de gemiddelde mobiliteitsbereidheid het grootst is, is de sector voeding, waar ruim $16 \%$ van de werknemers aangeeft een andere baan te zoeken of daarnaar recentelijk gezocht te hebben. Ook binnen de sectoren horeca, reparatie en zakelijke dienstverlening en handel ligt de mobiliteitsbereidheid relatief hoog met respectievelijk $14,1 \%$ en $13,8 \%$. Binnen de sector landbouw en visserij, de sector met de laagste mobiliteitsbereidheid, bedraagt het percentage werknemers dat van baan wil veranderen slechts $2,5 \%$. Opvallend is verder de relatief geringe mobiliteitsbereidheid binnen de sector bank- en verzekeringswezen, waar slechts $6,1 \%$ van de werknemers aangeeft naar een andere baan te zoeken of te hebben gezocht.

Uit de gevonden resultaten blijkt ook dat vrouwen in de meeste sectoren iets minder mobiliteitsbereid zijn dan mannen. Uitzonderingen hierop zijn de sectoren voeding, chemie, metaal en elektrotechniek en horeca, reparatie en zakelijke dienstverlening, waar vrouwen een bovengemiddelde mobiliteitsbereidheid hebben. In de sector chemie zijn de vrouwen het meest mobiliteitsbereid: een op de vier vrouwen heeft in deze sector naar een andere baan gezocht of is op zoek naar een andere baan. 
Jongeren scoren in nagenoeg elke sector boven gemiddeld wat betreft hun mobiliteitsbereidheid. Alleen in de sector transport en communicatie scoren zij beneden het gemiddelde. De jongeren die werkzaam zijn in de sector voeding, zijn het meest mobiliteitsbereid: ruim $36 \%$ zoekt of zocht recentelijk naar een andere baan. Bij de ouderen valt op dat zij over het algemeen niet op zoek zijn of recentelijk op zoek zijn geweest naar een andere baan. Met uitzondering van de sectoren voeding, waar $14,3 \%$ van de ouderen als mobiliteitsbereid kan worden aangemerkt, en metaal en elektrotechniek, waar $2,9 \%$ zoekt of recentelijk heeft gezocht naar een andere baan, is in de meeste sectoren niet meer dan $1 \%$ van de ouderen mobiliteitsbereid.

De laag opgeleiden blijken alleen in de sectoren landbouw en visserij en overheid en onderwijs een hogere mobiliteitsbereidheid te hebben dan de andere werknemers in de sector. In de overige sectoren zijn de laag opgeleiden minder mobiliteitsbereid dan gemiddeld. Met name in de sectoren energie en bank- en verzekeringswezen hebben de laag opgeleiden een relatief lage mobiliteitsbereidheid.

\section{Mobiliteitsvermogen}

Om het mobiliteitsvermogen van werknemers te kunnen inschatten, is gebruik gemaakt van de verblijfsduur van de werknemer in de huidige baan in de huidige functie, de totale verblijfsduur op de arbeidsmarkt, en de leeftijd van de werknemer. Op basis van deze drie variabelen is een indicator voor het mobiliteitsvermogen berekend. In tabel 3.2 is de verhouding tussen de verblijfsduur in de huidige functie en het totale verblijf op de arbeidsmarkt gecorrigeerd voor de leeftijd weergegeven in de vorm van een index. Deze index wordt per sector bepaald voor de totale groep werknemers en voor de onderscheiden doelgroepen.

Uit de totaalcijfers blijkt dat in de sectoren kwartaire diensten en overheid en onderwijs het mobiliteitsvermogen van de werknemers het geringst is. In de sectoren horeca, reparatie en zakelijke dienstverlening en bouw en onroerend goed is het mobiliteitsvermogen van de werknemers het grootst.

Het mobiliteitsvermogen van vrouwen blijkt in de meeste sectoren groter te zijn dan dat van de mannen. Vooral in de sector landbouw en visserij is het verschil groot. In de sectoren chemie, bouw en onroerend goed, handel, overheid en onderwijs en kwartaire diensten scoren vrouwen qua mobiliteitsvermogen echter wat minder gunstig dan mannen.

Bij de jongeren is het mobiliteitsvermogen vooral hoog in de sectoren bank- en verzekeringswezen en transport en communicatie. In de sector landbouw en visserij is het mobiliteitsvermogen van jongeren echter slechter dan dat van de andere werknemers in de sector, wat opvallend genoemd mag worden. Met uitzondering 
van de sector energie is in elke sector het mobiliteitsvermogen van ouderen geringer dan dat van jongeren. In de sector voeding is dat verschil het kleinst, in de sector transport en communicatie het grootst. Binnen de sectoren energie en voeding is het mobiliteitsvermogen van ouderen het grootst. In de sectoren kwartaire diensten, chemie en overheid en onderwijs is het vermogen tot mobiliteit het geringst.

Tabel 3.2

Mobiliteitsvermogensindex per bedrijfssector, 1996

\begin{tabular}{|c|c|c|c|c|c|}
\hline Bedrijfssector & totaal & vrouwen & jongeren & ouderen & opgeleiden \\
\hline Landbouw en visserij & 97 & 284 & 94 & 80 & 88 \\
\hline Voeding & 100 & 103 & 101 & 97 & 95 \\
\hline Chemie & 94 & 91 & 99 & 71 & 91 \\
\hline Metaal en elektrotechniek & 104 & 106 & 108 & 93 & 98 \\
\hline Overige industrie & 95 & 99 & 104 & 72 & 96 \\
\hline Energie & 105 & 116 & 144 & 215 & 102 \\
\hline Bouw en onroerend goed & 109 & 106 & 119 & 81 & \\
\hline Handel & 103 & 101 & 129 & 74 & 98 \\
\hline Transport en communicatie & 97 & 106 & 150 & 69 & 93 \\
\hline Bank- en verzekeringswezen & 104 & 122 & 154 & 76 & 95 \\
\hline $\begin{array}{l}\text { Horeca, reparatie en zakelijke } \\
\text { dienstverlening }\end{array}$ & & & & & \\
\hline dienstverlening & 112 & 116 & 121 & 85 & 103 \\
\hline Kwartaire diensten & 92 & 91 & 101 & 76 & 92 \\
\hline Overheid en onderwijs & 88 & 87 & 119 & 71 & 101 \\
\hline Totaal & 100 & 118 & 115 & 86 & 97 \\
\hline
\end{tabular}

Bron: OSA/ROA

Voor de meeste sectoren geldt dat laag opgeleiden een geringer mobiliteitsvermogen hebben dan middelbaar en hoger opgeleiden. Hierop zijn enkele positieve uitzonderingen. In de sectoren energie, horeca, reparatie en zakelijke dienstverlening en overheid en onderwijs scoren de laag opgeleiden bovengemiddeld qua mobiliteitsvermogen.

\subsection{Opleidingsbereidheid en -vermogen}

\section{Opleidingsbereidheid}

Opleidingsbereidheid van werknemers wordt in dit rapport geoperationaliseerd door het gemiddeld aantal cursussen dat werknemers per loopbaanjaar gevolgd hebben. In tabel 3.3 wordt deze indicator voor het totaal aantal werknemers en voor de verschillende doelgroepen gepresenteerd.

Het blijkt dat werknemers die werkzaam zijn in de sector bank- en verzekeringswezen, gemiddeld genomen de meeste scholing hebben gevolgd. Dit resultaat bevestigt de uitkomsten zoals die in Werkgelegenheid en scholing 1997 zijn gepresenteerd. Op de tweede plaats komen werknemers die werkzaam zijn in de sector 
horeca, reparatie en zakelijke dienstverlening, met gemiddeld ruim 0,2 cursus per jaar ( 1 cursus per 5 arbeidsjaren). De sector landbouw en visserij is de sector waarbinnen gemiddeld de minste cursussen per jaar worden gevolgd: 0,12. Qua opleidingsbereidheid komt ook de sector handel met gemiddeld 0,13 cursussen per jaar niet goed voor de dag.

Tabel 3.3

Opleidingsbereidheid per bedrijfssector, aantal cursussen per loopbaanjaar, 1996

\begin{tabular}{|c|c|c|c|c|c|}
\hline Bedrijfssector & totaal & vrouwen & jongeren & \multicolumn{2}{|c|}{ opgeleiden } \\
\hline Landbouw en visserij & 0,12 & 0,03 & 0,17 & 0,02 & 0,04 \\
\hline Voeding & 0,22 & 0,38 & 0,46 & 0,04 & 0,09 \\
\hline Chemie & 0,20 & 0,15 & 0,15 & 0,09 & 0,14 \\
\hline Metaal en elektrotechniek & 0,16 & 0,21 & 0,24 & 0,07 & 0,13 \\
\hline Overige industrie & 0,14 & 0,13 & 0,17 & 0,05 & 0,09 \\
\hline Energie & 0,22 & 0,48 & & 0,10 & 0,15 \\
\hline Bouw en onroerend goed & 0,16 & 0,26 & 0,19 & 0,08 & 0,20 \\
\hline Handel & 0,13 & 0,13 & 0,18 & 0,06 & 0,11 \\
\hline Transport en communicatie & 0,14 & 0,16 & 0,18 & 0,06 & 0,10 \\
\hline Bank- en verzekeringswezen & 0,32 & 0,34 & 0,60 & 0,24 & 0,27 \\
\hline Horeca, reparatie en & & & & & \\
\hline zakelijke dienstverlening & 0,23 & 0,18 & 0,29 & 0,12 & 0,15 \\
\hline Kwartaire diensten & 0,17 & 0,16 & 0,28 & 0,10 & 0,11 \\
\hline Overheid en onderwijs & 0,20 & 0,22 & 0,26 & 0,10 & 0,15 \\
\hline Totaal & 0,18 & 0,18 & 0,26 & 0,10 & 0,12 \\
\hline
\end{tabular}

Bron: OSA/ROA

Wanneer de opleidingsbereidheid van vrouwen vergeleken wordt met de opleidingsbereidheid van de gehele werknemerspopulatie, blijkt dat er over het geheel bezien weinig verschillen zijn. De opleidingsbereidheid van vrouwen verbijzonderd naar bedrijfssector levert wel een aantal duidelijke verschillen op. Zo volgen vrouwen in de sectoren landbouw en visserij, chemie, horeca, reparatie en zakelijke dienstverlening en kwartaire diensten gemiddeld genomen minder cursussen dan hun mannelijke collega's. De bedrijfssectoren voeding, metaal en elektrotechniek, energie, bouw en onroerend goed, transport en communicatie, bank en verzekeringswezen en overheid en onderwijs laten echter een omgekeerd beeld zien. In deze bedrijfssectoren zijn het de vrouwen die gemiddeld genomen meer cursussen volgen. Met name in de sector energie scoren vrouwen erg hoog, met gemiddeld 0,48 cursussen per jaar.

De verschillen in opleidingsbereidheid tussen jongeren en ouderen zijn erg groot. Uit de cijfers blijkt dat jongeren gemiddeld genomen eens in de vier jaar een cursus volgen. Voor ouderen ligt dat gemiddelde een stuk lager, namelijk eens in de tien jaar. De sector waar het verschil in de scholingsparticipatie tussen jongeren en ouderen het kleinst is, is de sector chemie. In de sector voeding is het verschil tussen 
jongeren en ouderen daarentegen het grootst, jongeren volgen in deze laatste sector gemiddeld ruim tien maal zoveel cursussen als ouderen.

Over het geheel genomen volgen laag opgeleiden ongeveer de helft minder cursussen dan middelbaar en hoog opgeleiden. Een uitzondering hierop vormt de sector bouw en onroerend goed, waar laag opgeleiden gemiddeld meer cursussen per jaar volgen dan middelbaar en hoog opgeleiden.

\section{Opleidingsvermogen}

Het opleidingsvermogen wordt bepaald aan de hand van het totaal aantal jaren dat een werknemer besteed heeft aan opleidingen of cursussen. Het totaal aantal opleidingsjaren is berekend als de optelsom van de nominale duur van de initiële opleiding (gerekend vanaf het verlaten van het basisonderwijs) en de totale duur van de cursussen die een werknemer tijdens zijn loopbaan heeft gevolgd. Het opleidingsvermogen per bedrijfssector wordt voor het totaal aantal werknemers en verbijzonderd naar de doelgroepen, gepresenteerd in tabel 3.4. Hierbij geldt dat des te hoger het totaal aantal opleidingsjaren des te groter het opleidingsvermogen.

Tabel 3.4

Opleidingsvermogen per bedrijfssector, totaal aantal opleidingsjaren, 1996

\begin{tabular}{|c|c|c|c|c|c|}
\hline Bedrijfssector & totaal & vrouwen & jongeren & ouderen & opgeleiden \\
\hline Landbouw en visserij & 5,5 & 5,4 & 5,5 & 3,9 & 4,4 \\
\hline Voeding & 6,0 & 6,2 & 6,0 & 2,9 & 4,7 \\
\hline Chemie & 7,3 & 6,0 & 6,5 & 7,4 & 5,5 \\
\hline Metaal en elektrotechniek & 6,5 & 5,4 & 5,7 & 6,8 & 5,5 \\
\hline Overige industrie & 6,2 & 6,1 & 5,3 & 5,3 & 4,7 \\
\hline Energie & 8,8 & 7,5 & & 10,1 & 8,7 \\
\hline Bouw en onroerend goed & 6,2 & 6,3 & 5,8 & 5,8 & 5,2 \\
\hline Handel & 5,9 & 5,4 & 5,6 & 5,5 & 4,8 \\
\hline Transport en communicatie & 5,6 & 5,5 & 5,9 & 5,5 & 4,4 \\
\hline Bank- en verzekeringswezen & 8,4 & 7,4 & 7,8 & 9,3 & 6,3 \\
\hline Horeca, reparatie en & & & & & \\
\hline zakelijke dienstverlening & 7,0 & 5,8 & 6,8 & 6,8 & 5,1 \\
\hline Kwartaire diensten & 7,2 & 6,8 & 6,4 & 7,1 & 5,5 \\
\hline Overheid en onderwijs & 8,9 & 8,7 & 7,6 & 9,6 & 6,7 \\
\hline Totaal & 7,0 & 6,7 & 6,2 & 7,2 & 5,3 \\
\hline
\end{tabular}

Over het geheel genomen volgen werknemers gemiddeld na de basisschool iets meer dan zeven jaar onderwijs. In de sector overheid en onderwijs ligt het gemiddelde per werknemer naar verhouding het hoogst, op 8,9 jaar. Daarnaast hebben de werknemers in de sectoren bank en verzekeringswezen en energie een relatief groot opleidingsvermogen. De werknemers in deze bedrijfssectoren zijn gemiddeld respectievelijk 8,4 en 8,8 jaar opgeleid. Werknemers in de sectoren landbouw en 
visserij en transport en communicatie hebben gemiddeld het minst aantal jaren opleiding gevolgd, respectievelijk 5,5 jaar en 5,6 jaar.

In vrijwel alle sectoren hebben vrouwen minder opleiding gevolgd dan mannen. Uitzonderingen hierop zijn de sectoren voeding, transport en communicatie en kwartaire diensten. Vooral in de sector transport en communicatie is het verschil in het voordeel van de vrouwelijke medewerkers groot. In de sector energie hebben de vrouwelijke werknemers daarentegen aanzienlijk minder scholing genoten dan de mannelijke werknemers.

Jongeren hebben gemiddeld minder jaren opleiding genoten dan ouderen. Jongeren hebben gemiddeld 6,2 jaar aan opleidingen en cursussen besteed, ouderen gemiddeld 7,2 jaar. Per sector lopen de verschillen echter nogal uiteen. Zo hebben jongeren binnen de sector voeding gemiddeld ruim drie jaar meer aan opleiding besteed dan de oudere werknemers in die sector. Voor de sectoren overheid en onderwijs en bank- en verzekeringswezen geldt dat ouderen zo'n twee jaar meer aan opleiding hebben besteed dan jongeren in diezelfde sectoren. De jongeren in de sector bank- en verzekeringswezen zijn gemiddeld het langst bezig geweest met opleidingen en cursussen, bijna 8 jaar. Ouderen die werkzaam zijn in de sector voeding hebben met gemiddeld 2,9 jaar opleiding het minste opleidingsvermogen. De ouderen in de sectoren energie en overheid en onderwijs zijn daarentegen de best geschoolde oudere werknemers met gemiddeld respectievelijk 10,1 jaar en 9,6 jaar opleiding.

Laag opgeleiden hebben vanzelfsprekend minder opleidingsjaren achter de rug dan middelbaar en hoger opgeleiden. Wanneer echter het gemiddelde per sector wordt beschouwd komen opvallende verschillen naar voren. Wat het meeste opvalt is dat in de sectoren chemie, metaal en elektrotechniek en energie de laag opgeleiden gemiddeld meer jaren aanvullende scholing en cursussen hebben gevolgd dan de middelbaar en hoog opgeleiden. De in deze sectoren werkzame laag opgeleiden volgen dus tijdens hun loopbaan meer cursussen. Van de laag opgeleiden hebben degenen die werkzaam zijn in de sector energie de meeste jaren scholing gevolgd (gemiddeld 8,7 jaar). Ook de laag opgeleiden in de sectoren overheid en onderwijs (gemiddeld 6,7 jaar scholing) en het bank- en verzekeringswezen (gemiddeld 6,3 jaar scholing) hebben relatief veel aanvullende scholing gevolgd. De laag opgeleide werknemers in de sectoren landbouw en visserij en voeding komen qua opleidingsvermogen als slechtsten uit de bus, zij hebben gemiddeld in totaal respectievelijk slechts 4,4 en 4,7 jaar scholing gevolgd. 


\subsection{Bereidheid en vermogen tot brede inzetbaarheid}

\section{Bereidheid tot brede inzetbaarheid}

De bereidheid van werknemers zich breed in te zetten is gemeten aan de hand van de vraag of werknemers, indien daartoe de noodzaak bestaat, bereid zijn werkzaamheden te verrichten die niet tot hun eigen functie behoren. In tabel 3.5 zijn de resultaten gepresenteerd, wederom eerst voor het totaal aantal werknemers in de sector, vervolgens verbijzonderd naar de onderscheiden doelgroepen. Vermeld is het percentage werknemers dat aangeeft bereid te zijn zich breed in te zetten.

Uit tabel 3.5 blijkt dat bijna driekwart van de werknemers bereid is werkzaamheden te verrichten die niet tot de eigen functie behoren. Vrouwelijke werknemers zijn gemiddeld wat minder bereid werkzaamheden te verrichten die niet tot hun eigen functie behoren dan mannelijke werknemers. Jongeren zijn over het algemeen iets eerder bereid breed te worden ingezet dan ouderen. Van de jongeren geeft ruim $73 \%$ aan bereid te zijn werkzaamheden te verrichten die niet tot de eigen functie behoren. Van de oudere werknemers is dat slechts $66 \%$. Laag opgeleide werknemers scoren qua bereidheid breed te worden ingezet gemiddeld. Het maakt voor de bereidheid om breed te worden ingezet dus niet uit of een werknemer laag, middelbaar of hoog opgeleid is.

Tussen de sectoren bestaan er duidelijke verschillen in de bereidheid van de werknemers om breed te worden ingezet. Werknemers in de sector landbouw en visserij zijn het meest bereid tot een brede inzet. Ruim $80 \%$ van de werknemers in deze sector geeft aan bereid te zijn werkzaamheden te verrichten buiten de eigen functie. De sectoren waar de werknemers het minst breed inzetbaar zijn, zijn de sectoren kwartaire diensten en voeding.

Bij de vrouwen is de bereidheid breed te worden ingezet ook het grootst in de sector landbouw en visserij. Het minst bereid om breed te worden ingezet zijn de vrouwelijke werknemers in de sectoren transport en communicatie en kwartaire diensten.

Jongere werknemers blijken het meest bereid tot een brede inzet in de sector banken verzekeringswezen. Het minst bereid tot een brede inzet zijn de jongeren die werkzaam zijn in de sector voeding. Slechts $59 \%$ van de jongeren die werkzaam zijn in deze sector zegt bereid te zijn zich breed in te zetten. Ook in de sector kwartaire diensten scoren de jongere werknemers qua bereidheid om breed te worden ingezet relatief laag ten opzichte van jongeren in andere sectoren. Bij de oudere werknemers valt allereerst op dat zij in de sectoren metaal en elektrotechniek en overige industrie vaker bereid zijn om breed te worden ingezet dan hun jongere collega's. Met name in de sector kwartaire diensten zijn relatief weinig oudere werk- 
nemers bereid om breed te worden ingezet. Slechts $56 \%$ geeft aan bereid te zijn andere werkzaamheden te verrichten die niet tot de eigen functie behoren.

Tabel 3.5

Bereidheid tot brede inzetbaarheid per bedrijfssector, 1996

\begin{tabular}{lrrrrr}
\hline Bedrijfssector & totaal & vrouwen & jongeren & $\begin{array}{r}\text { ouderen } \\
\text { opgeleiden } \\
\%\end{array}$ \\
& $\%$ & $\%$ & $\%$ & $\%$ & $\begin{array}{r}\text { laag } \\
\text { Landbouw en visserij }\end{array}$ \\
Voeding & 84 & 83 & 71 &. & 86 \\
Chemie & 67 & 67 & 59 & 60 & 75 \\
Metaal en elektrotechniek & 71 & 69 & 63 & 83 & 75 \\
Overige industrie & 79 & 72 & 81 & 86 & 93 \\
Energie & 85 & 89 & 85 & 75 \\
Bouw en onroerend goed & 77 & 67 & 75 & 73 & 75 \\
Handel & 77 & 85 & 75 & 63 & 72 \\
Transport en communicatie & 74 & 71 & 76 & 67 & 69 \\
Bank- en verzekeringswezen & 69 & 52 & 76 & 65 & 73 \\
Horeca, reparatie en zakelijke & 79 & 78 & 84 & 66 & 68 \\
dienstverlening & 71 & 60 & 73 & 56 & 58 \\
Kwartaire diensten & 63 & 59 & 62 & 55 & 79 \\
Overheid en onderwijs & 72 & 68 & 74 & 66 & 72 \\
Totaal & 72 & 65 & 74 & 66 \\
\hline
\end{tabular}

Bron: OSA/ROA

Bij de laag opgeleiden blijkt de bereidheid om breed te worden ingezet met name in de landbouw en visserij groot. In de sector kwartaire diensten is de bereidheid tot een brede inzet wederom het geringst: slechts $58 \%$ wil eventueel werkzaamheden verrichten die niet tot hun eigen functie behoren. Opvallend is verder dat in de sectoren landbouw en visserij, chemie, overige industrie, energie en overheid en onderwijs de laag opgeleiden vaker bereid zijn breed te worden ingezet dan de middelbaar en hoog opgeleiden.

\section{Vermogen tot brede inzetbaarheid}

Het vermogen van medewerkers om zich breed in te zetten is bepaald met behulp van gegevens omtrent de frequentie waarmee werknemers werkzaamheden hebben verricht die niet tot hun eigen functie behoren. Het vermogen tot brede inzetbaarheid wordt dus bepaald aan de hand van de ervaring die werknemers ermee hebben opgedaan. In tabel 3.6 is de gemiddelde score voor het vermogen om breed te worden ingezet weergegeven, per sector en verbijzonderd naar de onderscheiden doelgroepen.

Uit tabel 3.6 blijkt dat met name in de sectoren chemie en landbouw en visserij het vermogen van werknemers om breed te worden ingezet groot is. De sector bank- en verzekeringswezen springt er daarentegen op dit punt in negatieve zin uit. 
Gemiddeld verrichten werknemers in die sector het minst vaak werkzaamheden die niet tot de eigen functie behoren. Vrouwen blijken over het algemeen iets minder vaak werkzaam op andere gebieden dan de eigen functie dan mannen. Jongere werknemers scoren gemiddeld beter dan oudere werknemers. Ook laag opgeleiden hebben een relatief hoog vermogen om breed te worden ingezet.

Tabel 3.6

Vermogen tot brede inzetbaarheid per bedrijfssector, 1996*

\begin{tabular}{|c|c|c|c|c|c|}
\hline Bedrijfssector & totaal & vrouwen & jongeren & \multicolumn{2}{|c|}{ opgeleiden } \\
\hline Landbouw en visserij & 1,7 & 1,8 & 1,5 & . & 1,6 \\
\hline Voeding & 1,6 & 1,3 & 1,5 & 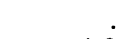 & 1,5 \\
\hline Chemie & 1,7 & 1,6 & 2,1 & 1,3 & 1,6 \\
\hline Metaal en elektrotechniek & 1,5 & 1,3 & 1,4 & 1,3 & 1,6 \\
\hline Overige industrie & 1,6 & 1,7 & 1,6 & 1,7 & 1,7 \\
\hline Energie & 1,4 & 1,3 & 1,3 & 1,2 & 1,4 \\
\hline Bouw en onroerend goed & 1,6 & 1,5 & 1,5 & 1,5 & 1,5 \\
\hline Handel & 1,6 & 1,7 & 1,7 & 1,6 & 1,7 \\
\hline Transport en communicatie & 1,4 & 1,3 & 1,4 & 1,2 & 1,5 \\
\hline Bank- en verzekeringswezen & 1,3 & 1,5 & 1,4 & 1,2 & 1,1 \\
\hline Horeca, reparatie en zakelijke & & & & & \\
\hline dienstverlening & 1,5 & 1,5 & 1,5 & 1,3 & 1,6 \\
\hline Kwartaire diensten & 1,4 & 1,4 & 1,5 & 1,4 & 1,4 \\
\hline Overheid en onderwijs & 1,5 & 1,4 & 1,5 & 1,5 & 1,5 \\
\hline Totaal & 1,5 & 1,5 & 1,6 & 1,4 & 1,6 \\
\hline
\end{tabular}

* gemiddelde scores op schaal 0 ('nog nooit voorgekomen'). Tot 3 ('vaak'); zie paragraaf 2.4 Bron: OSA/ROA

Vrouwelijke werknemers in de sector landbouw en visserij hebben het grootste vermogen zich breed in te zetten. Vrouwelijke werknemers hebben behalve in de sector landbouw en visserij ook in de sectoren handel en bank- en verzekeringswezen een groter vermogen zich breed in te zetten dan mannelijke werknemers in die sectoren. Met name in de sector bank- en verzekeringswezen is het verschil tussen mannelijke en vrouwelijke werknemers groot te noemen. In de sector voeding is het vermogen van vrouwen zich breed in te zetten daarentegen een stuk kleiner dan dat van de mannen in die sector.

Als wordt gekeken naar verschillen in het vermogen zich breed in te zetten naar leeftijd, blijkt dat er in de sector chemie de grootste verschillen tussen jongeren en ouderen bestaan. In deze sector scoren jongeren aanzienlijk beter dan ouderen. Ook in de sector handel doen jongeren het relatief goed wat betreft hun vermogen zich breed in te zetten. Bij de jongeren hebben degenen die werkzaam zijn in de sector energie het vermogen zich breed in te zetten. Bij de oudere werknemers hebben de werknemers die werkzaam zijn in de sectoren energie, bank-en verzekeringswezen en transport en communicatie het geringste vermogen tot een brede inzet. 
De laag opgeleiden scoren zoals gezegd beter dan de middelbaar en hoger opgeleiden wat betreft hun vermogen breed te worden ingezet. Met name in de sector handel hebben de laag opgeleiden een groot vermogen om breed te worden ingezet. Bij de laag opgeleiden in de sectoren energie, kwartaire diensten en bank- en verzekeringswezen is het vermogen zich breed in te zetten relatief laag ten opzichte van de laag opgeleiden in andere sectoren.

\subsection{M.O.I. per bedrijfssector}

De M.O.I.-score wordt bepaald door het gemiddelde te berekenen van de indexcijfers op de indicatoren per bedrijfssector. Hierbij is het overall-gemiddelde van de totale groep werknemers op 100 gesteld.

Tabel 3.7

M.O.I. per bedrijfssector*

\begin{tabular}{|c|c|c|c|c|c|c|c|}
\hline Bedrijfssector & MB & MV & $\mathrm{OB}$ & OV & IB & \multicolumn{2}{|c|}{ IV M.O.I. } \\
\hline Landbouw en visserij & 85 & 97 & 91 & 91 & 111 & 110 & 97 \\
\hline Voeding & 114 & 100 & 105 & 95 & 91 & 104 & 101 \\
\hline Chemie & 103 & 94 & 102 & 103 & 97 & 112 & 102 \\
\hline Metaal en elektrotechniek & 102 & 104 & 96 & 98 & 105 & 98 & 100 \\
\hline Overige industrie & 101 & 95 & 94 & 96 & 113 & 107 & 101 \\
\hline Energie & 93 & 105 & 105 & 112 & 103 & 94 & 102 \\
\hline Bouw en onroerend goed & 100 & 109 & 96 & 95 & 103 & 104 & 101 \\
\hline Handel & 109 & 103 & 92 & 94 & 100 & 106 & 100 \\
\hline Transport en communicatie & 97 & 97 & 94 & 92 & 94 & 93 & 94 \\
\hline Bank- en verzekeringswezen & 92 & 104 & 119 & 110 & 105 & 85 & 103 \\
\hline Horeca, reparatie en zakelijke dienstverlening & 109 & 112 & 106 & 101 & 96 & 96 & 103 \\
\hline Kwartaire diensten & 100 & 92 & 98 & 102 & 87 & 94 & 96 \\
\hline Overheid en onderwijs & 95 & 88 & 102 & 113 & 97 & 98 & 99 \\
\hline
\end{tabular}

* $\mathrm{MB}=$ mobiliteitsbereidheid; $\mathrm{MV}=$ mobiliteitsvermogen; $\mathrm{OB}=$ Opleidingsbereidheid; $\mathrm{OV}=$ opleidingsvermogen; IB= inzetbaarheidsbereidheid; IV= vermogen tot brede inzetbaarheid; M.O.I = Index Mobiliteit, Opleiding en Inzetbaarheid. Bron: ROA

Tabel 3.7 bevat de M.O.I. per bedrijfssector voor de gehele werknemerspopulatie. Uit de tabel blijkt dat werknemers in de sectoren horeca, reparatie en zakelijke dienstverlening en bank- en verzekeringswezen de beste individuele employability hebben. In de horeca, reparatie en zakelijke dienstverlening is met name de mobiliteitsbereidheid, het mobiliteitsvermogen en ook de opleidingsbereidheid relatief hoog. In het bank- en verzekeringswezen zijn vooral de opleidingsbereidheid en het opleidingsvermogen van de werknemers groot. Ook bij de werknemers in de sectoren chemie en energie is de individuele employability relatief hoog. In de chemie is vooral het vermogen van de werknemers om breed te worden ingezet relatief groot. In de sector energie is met name het opleidingsvermogen van de werknemers groot. De werknemers die in de sectoren transport en communicatie, kwartaire diensten of landbouw en visserij werkzaam zijn, hebben daarentegen de geringste individuele employability. De werknemers in de sector transport en communicatie scoren 
op alle aspecten van de individuele employability relatief laag. Bij de werknemers in de kwartaire sector is vooral de bereidheid om breed te worden ingezet en het mobiliteitsvermogen relatief laag. Bij de werknemers in de sector landbouw en visserij is vooral de mobiliteitsbereidheid laag.

Tabel 3.8

M.O.I. per bedrijfssector, vrouwen*

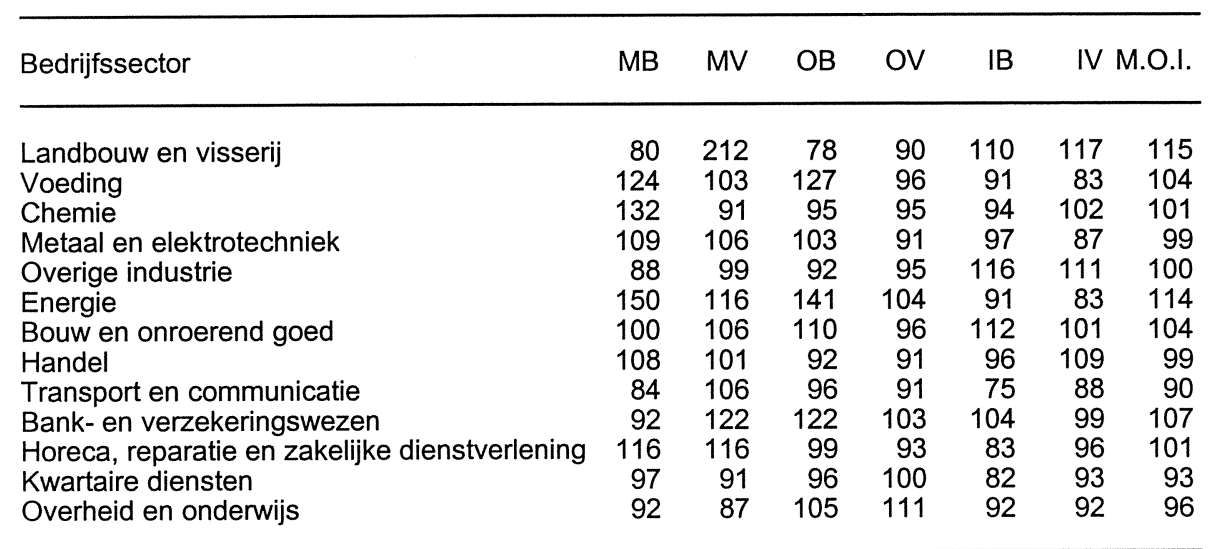

* zie noot tabel 3.7

Bron: ROA

In tabel 3.8 is de M.O.I. per bedrijfssector weergegeven voor alleen vrouwelijke werknemers. Op een aantal punten wijken de resultaten af van het beeld dat in tabel 3.7 werd geschetst van het totaal aantal werknemers in de verschillende sectoren. Van de vrouwelijke werknemers zijn opmerkelijk genoeg degenen die in de sector landbouw en visserij werkzaam zijn het meest employable. Dit is in belangrijke mate toe te schrijven aan hun hoge mobiliteitsvermogen. Daarnaast zijn ook vrouwelijke werknemers in de sectoren bank- en verzekeringswezen en energie relatief employable. Bij de vrouwen die werkzaam zijn in het bank- en verzekeringswezen zijn vooral het mobiliteitsvermogen en de opleidingsbereidheid groot. Bij de vrouwen die werkzaam zijn in de sector energie zijn vooral de mobiliteitsbereidheid en de opleidingsbereidheid hoog. De vrouwelijke werknemers in de sectoren bouw en onroerend goed en voeding komen qua individuele employability op een gedeelde vierde plaats. Het minst employable zijn de vrouwelijke werknemers die werken in de sectoren transport en communicatie en kwartaire diensten. Bij de vrouwen die werkzaam zijn in de kwartaire diensten is met name de bereidheid om breed te worden ingezet laag.

In tabel 3.9 wordt de M.O.I. weergegeven van de jongere werknemers (16-29 jaar) per bedrijfssector. De tabel laat zien dat de individuele employability van de jongeren in vrijwel alle sectoren groter is dan de gemiddelde employability van de werknemers in de desbetreffende sector. Bij de jongere werknemers in de sector landbouw en visserij is de employability aanzienlijk slechter dan bij de jongeren, die in 
andere sectoren werkzaam zijn. Op alle aspecten van de individuele employability scoren de jongeren die werkzaam zijn in de landbouw en visserij laag. Ook in de sectoren bouw en onroerend goed en kwartaire diensten zijn de jongere werknemers relatief weinig employable. In de sector bouw en onroerend goed is vooral het opleidingsvermogen van de jongeren laag. In de kwartaire diensten is met name de bereidheid om breed te worden ingezet gering. Qua individuele employability komen de jongere werknemers in de sectoren bank- en verzekeringswezen, energie, voeding en overheid en onderwijs het beste uit de bus. In al deze sectoren is de opleidingsbereidheid van jongeren erg groot. Daarnaast is in deze sectoren ook de mobiliteitsbereidheid en/of het mobiliteitsvermogen van de jongeren groot.

Tabel 3.9

M.O.I. per bedrijfssector, jongeren*

\begin{tabular}{|c|c|c|c|c|c|c|c|}
\hline Bedrijfssector & MB & MV & $\mathrm{OB}$ & OV & IB & \multicolumn{2}{|c|}{ IV M.O.I. } \\
\hline Landbouw en visserij & 94 & 94 & 98 & 91 & 97 & 99 & 95 \\
\hline Voeding & 157 & 101 & 139 & 94 & 82 & 101 & 112 \\
\hline Chemie & 135 & 99 & 95 & 97 & 87 & 134 & 108 \\
\hline Metaal en elektrotechniek & 117 & 108 & 108 & 93 & 108 & 93 & 104 \\
\hline Overige industrie & 129 & 104 & 98 & 90 & 112 & 103 & 106 \\
\hline Energie & 132 & 144 & 133 & 93 & 101 & 88 & 115 \\
\hline Bouw en onroerend goed & 107 & 119 & 101 & 93 & 101 & 100 & 103 \\
\hline Handel & 129 & 129 & 99 & 92 & 102 & 111 & 110 \\
\hline Transport en communicatie & 96 & 150 & 99 & 94 & 102 & 93 & 106 \\
\hline Bank- en verzekeringswezen & 113 & 154 & 160 & 106 & 111 & 90 & 122 \\
\hline Horeca, reparatie en zakelijke dienstverlening & 124 & 121 & 115 & 99 & 98 & 101 & 110 \\
\hline Kwartaire diensten & 114 & 101 & 113 & 97 & 85 & 101 & 102 \\
\hline Overheid en onderwijs & 112 & 119 & 134 & 104 & 100 & 100 & 112 \\
\hline
\end{tabular}

* zie noot tabel 3.7

Bron: ROA

Tabel 3.10 bevat de M.O.I.-scores van de oudere werknemers per bedrijfssector. De M.O.I.-scores voor de oudere werknemers laten zien dat de individuele employability van de ouderen in bijna alle sectoren duidelijk achter blijft bij de gemiddelde employability van de werknemers in de desbetreffende sector. Alleen in de sectoren energie en landbouw en visserij is de individuele employability van de oudere werknemers bovengemiddeld. De oudere werknemers in de sectoren landbouw en visserij en energie scoren in vergelijking met oudere werknemers in andere sectoren qua individuele employability het best. Met name de bereidheid en het vermogen tot een brede inzetbaarheid is bij deze oudere werknemers in deze sector groot. In de sectoren transport en communicatie en chemie is de individuele employability van ouderen daarentegen het minst gunstig. In beide sectoren is vooral het mobiliteitsvermogen van de oudere werknemers laag. 
Tabel 3.10

M.O.I. per bedrijfssector, ouderen*

\begin{tabular}{lrrrrrrr}
\hline Bedrijfssector & MB & MV & OB & OV & IB & IV M.O.I. \\
\hline Landbouw en visserij & & & & & & & \\
Voeding & 80 & 80 & 77 & 81 & 130 & 145 & 98 \\
Chemie & 110 & 97 & 80 & 75 & 80 & 114 & 92 \\
Metaal en elektrotechniek & 80 & 71 & 87 & 103 & 83 & 88 & 85 \\
Overige industrie & 86 & 93 & 84 & 99 & 110 & 83 & 92 \\
Energie & 80 & 72 & 81 & 90 & 113 & 109 & 91 \\
Bouw en onroerend goed & 80 & 215 & 88 & 120 & 97 & 80 & 113 \\
Handel & 80 & 81 & 85 & 93 & 99 & 99 & 89 \\
Transport en communicatie & 80 & 74 & 82 & 91 & 87 & 105 & 86 \\
Bank- en verzekeringswezen & 80 & 69 & 82 & 91 & 91 & 80 & 82 \\
Horeca, reparatie en zakelijke dienstverlening & 80 & 76 & 108 & 115 & 89 & 79 & 91 \\
Kwartaire diensten & 80 & 85 & 91 & 99 & 90 & 89 & 89 \\
Overheid en onderwijs & 82 & 76 & 88 & 101 & 78 & 93 & 86 \\
& 81 & 71 & 88 & 117 & 89 & 98 & 91 \\
\hline
\end{tabular}

* Zie noot tabel 3.7

Bron: ROA

Ten slotte wordt in tabel 3.11 een overzicht gegeven van de individuele employability van laag opgeleiden in de verschillende bedrijfssectoren. Met uitzondering van de sector overheid en onderwijs blijken lager opgeleiden in alle sectoren een relatief geringe employability te hebben. Het slechtst is de employability van laag opgeleiden in de sectoren voeding en kwartaire diensten. In de voedingssector scoren de laag opgeleiden op de meeste aspecten van de individuele employability slecht.

Tabel 3.11

M.O.I. per bedrijfssector, laag opgeleiden*

\begin{tabular}{lrrrrrrr}
\hline Bedrijfssector & MB & MV & OB & OV & IB & IV M.O.I. \\
\hline Landbouw en visserij & 88 & 88 & 80 & 84 & 114 & 107 & 93 \\
Voeding & 92 & 95 & 87 & 86 & 89 & 99 & 91 \\
Chemie & 95 & 91 & 94 & 91 & 101 & 106 & 96 \\
Metaal en elektrotechniek & 97 & 98 & 92 & 91 & 100 & 107 & 98 \\
Overige industrie & 91 & 96 & 87 & 86 & 121 & 112 & 99 \\
Energie & 80 & 102 & 95 & 111 & 105 & 92 & 97 \\
Bouw en onroerend goed & 94 & 106 & 89 & 89 & 100 & 101 & 97 \\
Handel & 107 & 98 & 89 & 87 & 97 & 111 & 98 \\
Transport en communicatie & 96 & 93 & 88 & 84 & 94 & 97 & 92 \\
Bank- en verzekeringswezen & 80 & 95 & 112 & 96 & 98 & 77 & 93 \\
Horeca, reparatie en zakelijke dienstverlening & 102 & 103 & 95 & 88 & 92 & 104 & 97 \\
Kwartaire diensten & 98 & 92 & 89 & 91 & 81 & 91 & 90 \\
Overheid en onderwijs & 95 & 101 & 95 & 99 & 105 & 101 & 99 \\
& *Zie noot tabel 3.7. & & & & & & \\
Bron: ROA & & & & & & &
\end{tabular}

Bron: ROA

In de kwartaire diensten is met name de bereidheid breed te worden ingezet laag. Ook in de sector transport en communicatie doen de laag opgeleide werknemers het 
wat betreft hun individuele employability relatief slecht. Ook in deze sector is met name de opleidingsbereidheid en het opleidingsvermogen van de laag opgeleiden gering. In de sector overheid en onderwijs scoren de laag opgeleide werknemers in vergelijking tot laag opgeleide werknemers in andere sectoren het beste, gevolgd door de sectoren metaal en electrotechniek en handel.

In de sector overheid en onderwijs is onder laag opgeleiden met name de bereidheid breed te worden ingezet relatief hoog. Bij de laag opgeleiden in de metaal en elektrotechniek is vooral het vermogen om breed te worden ingezet wat groter. De laag opgeleiden die werkzaam zijn in de handel scoren vooral goed op het punt van de mobiliteitsbereidheid. 


\section{Maatschappelijke ontwikkelingen en behoefte aan employability per bedrijfssector}

\subsection{Inleiding}

Enkele maatschappelijke ontwikkelingen die van invloed zijn op de organisatie en haar productieprocessen vormen het vertrekpunt bij de bepaling van de 'behoefte' aan employability per bedrijfssector. De intensiteit van deze ontwikkelingen geeft een indicatie voor de mate waarin een actief employability beleid gewenst is in de verschillende sectoren. In hoofdstuk 5 zullen deze ontwikkelingen afgezet worden tegen de M.O.I. indicator, zodat eventuele employability tekorten aan het licht komen.

Dit hoofdstuk is gewijd aan de beschrijving en de kwantificering van vier belangrijke maatschappelijke ontwikkelingen die aanleiding geven om een actief employability beleid te voeren. Het gaat achtereenvolgens om technologische, organisatorische, economische en demografische ontwikkelingen. In paragraaf 4.2 worden de genoemde ontwikkelingen eerst kort beschreven. Daarna zal worden aangegeven op welke wijze ze geïndiceerd zullen worden en worden ze ook concreet ingevuld. In paragraaf 4.3 komen de technologische ontwikkelingen aan de orde. In paragraaf 4.4 wordt ingegaan op de organisatorische ontwikkelingen. Vervolgens worden de economische ontwikkelingen belicht in paragraaf 4.5. De demografische ontwikkelingen zijn het onderwerp van paragraaf 4.6. In de laatste paragraaf worden de indicatoren van de verschillende ontwikkelingen gecombineerd tot één indicator, die een overkoepelend beeld geeft van de behoefte aan employability per bedrijfssector.

In tegenstelling tot het vorige hoofdstuk zullen de indicatoren niet gepresenteerd worden per doelgroep. Aangezien de gebruikte data veelal betrekking hebben op bedrijfs- of sectorniveau, is dit niet mogelijk. Impliciet wordt daarbij derhalve aangenomen dat de geschetste ontwikkelingen alle werkenden in een bepaalde bedrijfssector in dezelfde mate noodzaken om employable te zijn.

\subsection{Maatschappelijke ontwikkelingen}

Zoals al eerder werd aangegeven, zullen er in dit rapport vier maatschappelijke ontwikkelingen worden besproken. In deze paragraaf wordt op iedere soort ontwikkeling kort ingegaan. Achtereenvolgens worden technologische, organisatorische, economische en demografische ontwikkelingen behandeld.

Bij technologische ontwikkelingen gaat het vooral om ontwikkelingen in de informatie- en communicatietechnologie. Deze ontwikkelingen leiden vooral tot functiespecifieke kwalificatieveroudering; waarbij aanwezige kennis en vaardigheden niet langer toereikend zijn voor een adequate functievervulling. Deze functie- 
specifieke kwalificatieveroudering zal leiden tot een verhoogd risico op verlies van werk. Technologische ontwikkelingen hebben niet tot een absolute afname van de werkgelegenheid geleid, maar tot een verschuiving in de aard van de vraag naar arbeid. Zo is als gevolg van technologische veranderingen de vraag naar laaggeschoolde arbeid in de industrie de laatste jaren afgenomen, terwijl deze in delen van de dienstensector juist toeneemt (Van Vliet, 1996). De vraag naar hoog opgeleide werknemers daarentegen neemt ook in de industrie toe, mede als gevolg van technologische ontwikkelingen (Machin, Ryan en Van Reenan, 1996). Volgens De Grip en Hoevenberg (1996) is dit laatste een direct gevolg van de zogeheten 'upgrading' van functies. Met upgrading wordt bedoeld dat de functie-eisen steeds zwaarder worden. De upgrading die plaatsheeft als gevolg van technologische ontwikkelingen leidt er dus toe dat de vraag naar hoger opgeleide werknemers toeneemt. Het werken aan employability van werknemers kan voorkomen dat er kwalificatieachterstanden ontstaan. Daarnaast is een gunstige employability van groot belang indien functies in het geheel verdwijnen, bijvoorbeeld als gevolg van grote automatiseringsoperaties, zoals die de laatste jaren binnen de banksector werden uitgevoerd (zie ook: ROA, 1998a).

Daarnaast zijn diverse organisatorische ontwikkelingen van belang. Van de organisatie wordt een grote mate van flexibiliteit geëist, doordat de omgeving meer dan ooit gekenmerkt wordt door snelle veranderingen. De organisatie moet immers kunnen anticiperen op deze veranderingen. De belangrijkste organisatorische ontwikkelingen zijn onverbrekelijk verbonden met de reeds besproken ontwikkelingen. Met name de snelle technologische en economische veranderingen vragen om voortdurende aanpassingen op organisatorisch vlak. Zo kunnen technologische ontwikkelingen, zoals bijvoorbeeld de vergaande informatisering en automatisering, leiden tot een verbreding c.q. upgrading van het takenpakket in uitvoerende functies.

Maroy en Fusulier (1995) onderscheiden vier verschillende soorten veranderingen waarop door scholing moet worden ingespeeld:

- Interne veranderingen van kleine omvang, zoals het opknappen van machines en het inwerken van de aangetrokken werknemers. De scholing is in dat geval voornamelijk gericht op een korte termijn aanpassing van de kwalificaties van de werknemers.

- Grote veranderingen op technisch vlak, zonder dat de organisatorische structuur ingrijpend wijzigt. Opleidingen spelen hier een faciliterende rol om de technologische verandering zo efficiënt mogelijk door te kunnen voeren.

- Meerdere, opeenvolgende, kleine veranderingen in het productieproces. Deze kunnen het best worden opgevangen door een opleidingssysteem dat de veranderingen begeleidt door het aanbieden van de relevante vereiste kennis. Overigens wordt in een dergelijk opleidingssysteem niet alleen technische kennis overgedragen; ook scholing gericht op het verwerven van sociale vaardigheden kan er deel van uitmaken. 
- Ingrijpende aanpassingen in de organisatiestructuur die als gevolg van toenemende concurrentie noodzakelijk zijn. Hier vormen opleidingen een prominent onderdeel van het veranderingsproces. Er zijn in een dergelijke situatie verschillende nieuwe vaardigheden nodig en de opleidingen zullen daarom langer van duur zijn.

Deze organisatorische veranderingen vragen van werknemers een zeer flexibele houding. Employability-beleid kan een peiler vormen bij de totstandbrenging van een dergelijke houding. Employability van werknemers impliceert immers naast een opleidingsbereide instelling ook een brede inzetbaarheid en een grote mobiliteitsbereidheid. Werknemers worden bij een op employability gericht beleid geconfronteerd met regelmatige veranderingen in de werkomgeving, zodat steeds gemakkelijker met dergelijke veranderingen kan worden omgegaan. De organisatorische ontwikkelingen die zich dan voordoen zullen gemakkelijker worden geaccepteerd, waardoor de organisatie sneller op nieuwe ontwikkelingen kan inspelen.

De belangrijkste economische ontwikkeling is de toenemende internationale concurrentie, met name binnen de Europese Unie, maar ook daarbuiten. In het Witboek van de Europese Commissie (1993) wordt aangegeven dat de lidstaten van de Europese Unie op een aantal terreinen tekort zijn geschoten. Met name op het gebied van kosten kunnen zij de concurrentie met een aantal lage lonen landen (bijvoorbeeld de 'Newly Industrializing Countries') niet aan. De vraag naar laaggeschoolde werknemers neemt in de Europese landen af doordat deze lage lonen landen de arbeidsintensieve productie en dus de vraag naar laaggeschoolde werknemers naar zich toe trekken (Wood, 1995). De strategische heroriëntatie die nodig zal zijn om op andere gebieden concurrerend te blijven of worden heeft voor werknemers verstrekkende implicaties. Deze heroriëntatie heeft vooral betrekking op de omschakeling van arbeidsintensieve productie naar kennisintensieve productie. De concurrentie met andere landen wordt dan ook met name gevoerd op het terrein van kennis. In analyses van de internationale concurrentiepositie van een land is het beschikbare human capital in het afgelopen decennium een prominente rol gaan spelen (Porter, 1990; zie ook Jacobs, cs., 1990). Hieraan ten grondslag ligt het idee dat bevorderen van human capital de productiviteit van werknemers opvoert (Cörvers, 1997). Technologische kennis wordt daardoor steeds vaker als de belangrijkste factor voor de concurrentiekracht van bedrijfssectoren aangemerkt (bv. Dosi, Pavitt en Soete, 1990). De opleiding van werknemers is daarbij in belangrijke mate bepalend voor het innoverende vermogen van organisaties en sectoren. Goed opgeleide werknemers zijn immers goede innovatoren (Bartel en Lichtenberg, 1987). Naast het gegeven dat goed opgeleide werknemers aan de basis staan van het innovatief vermogen van organisaties, speelt het opleidingsniveau van werknemers ook een rol bij de diffusie van technologische ontwikkelingen (Nelson en Phelps, 1966). Naast de goede opleiding staat ook een flexibele inzet van werknemers centraal voor een optimale bedrijfsvoering. Zijn werknemers goed opgeleid en zijn zij daarbij flexibel 
inzetbaar dan kan van zeer waardevolle arbeidskrachten worden gesproken. Employability-beleid gericht op de uitbreiding en het onderhoud van het human capital alsmede de flexibele inzetbaarheid van werknemers is derhalve van groot belang voor de internationale concurrentiekracht van het bedrijfsleven.

Ten slotte geven ook demografische ontwikkelingen zoals de ontgroening en vergrijzing van de beroepsbevolking aanleiding tot het schenken van aandacht aan de employability van (oudere) werknemers. Uit scenario-analyses van het CPB blijkt dat het aandeel 55+-ers in de beroepsbevolking in de periode 1995-2020 verdubbelt of zelfs verdrievoudigt. Het grootste deel van deze stijging vindt reeds plaats in de periode 1995-2010 (CBS/CPB, 1997). Ook de groep 40-54-jarigen zal in omvang toenemen. De groep werknemers jonger dan 40 jaar wordt daarentegen steeds kleiner, zowel in absolute als in relatieve zin (CBS/CPB, 1997). De ontgroening zal volgens de $\mathrm{CPB}$ prognoses rond 2010 stagneren. De vergrijzing zet echter ook na 2010 door (CBS/CPB, 1997).

De vergrijzing van de beroepsbevolking leidt ertoe dat veel van de in de afgelopen decennia sterk in omvang toegenomen uittredingswegen (VUT, WAO) voor oudere werknemers worden afgesloten, eenvoudigweg omdat ze steeds moeilijker te financieren worden. Voor werkgevers zal het ook steeds belangrijker worden werknemers langer aan de slag te houden, doordat het steeds moeilijker zal worden om jonge werknemers aan te trekken, als gevolg van de ontgroening. Beide ontwikkelingen geven derhalve aanleiding alles in het werk te stellen om de arbeidsmarktpositie van oudere werknemers te verbeteren.

De kansen van oudere werknemers om bij verlies van hun baan weer aan de slag te komen in andere organisaties zijn echter nog steeds gering (o.a. Bélanger en Falgàs, 1997). Dat de oudere werkzoekenden geringere kansen hebben op de arbeidsmarkt komt allereerst voort uit heersende stereotypen onder werkgevers. Oudere werknemers worden namelijk nog steeds gezien als star, traag, niet ambitieus, minder vitaal en allesbehalve flexibel (o.a. Boerlijst e.a., 1994).

Uit onderzoek van Boerlijst e.a. (1994) blijkt dat de meerderheid van de leidinggevenden in organisaties een ideale leeftijdsopbouw voor ogen heeft waarbij de gemiddelde leeftijd beneden de veertig jaar ligt en de voorkeur uitgaat naar een overwicht van werknemers onder die gemiddelde leeftijd. De stereotypering is niet alleen een van de belangrijkste oorzaken voor het feit dat ouderen minder kans maken op de arbeidsmarkt. Ook voor de investeringen van werkgevers in de ontwikkeling van oudere werknemers vormt de stereotypering een hindernis. Oudere werknemers blijken ook aanzienlijk minder kansen te krijgen zich binnen de organisatie te verplaatsen (Boerlijst e.a., 1994; zie ook Brook Street, 1990). 
Andere redenen waarom werkgevers minder geneigd zijn in de ontwikkeling van ouderen te investeren hebben, aldus Van Dalen (1993), te maken met de kortere periode waarin een ontwikkelingsinvestering rendement oplevert; het huidige kennisniveau, dat door de gebrekkige investeringen erin relatief laag is en de substitutiemogelijkheden om oudere werknemers te vervangen door fysiek kapitaal of een jongere werknemer. Door de voor de werkgever ongunstige verhouding tussen het loon en de productiviteit van de oudere werknemer is deze substitutie-optie vaak erg aantrekkelijk. Als gevolg van de ontgroening en vergrijzing van de beroepsbevolking wordt de optie om oudere werknemers te vervangen door jongere echter steeds minder reëel. Het op peil houden en verder ontwikkelen van het human capital van de oudere werknemers is nodig om te voorkomen dat in de nabije toekomst een tekort ontstaat aan voldoende gekwalificeerde werknemers (zie ook ROA, 1997a).

\subsection{Technologische ontwikkelingen}

Technologische ontwikkelingen kunnen bepaalde kansen scheppen voor werknemers. Tegelijkertijd kunnen deze ontwikkelingen echter een belangrijke bedreiging vormen voor hun arbeidsmarktpositie. De snelle veranderingen in het werk, die door technologische vernieuwingen veroorzaakt worden, vergen van werknemers een groot aanpassingsvermogen en vaak ook een brede inzetbaarheid.

De intensiteit waarmee technologische veranderingen zich voordoen zal hier geïndiceerd worden op basis van het percentage werkenden per bedrijfssector dat bij de uitoefening van het werk een computer gebruikt. Aangezien veel technologische veranderingen direct of indirect gerelateerd zijn aan verbeteringen of veranderingen aan computerapparatuur en/of -software, geeft deze indicator aan in welke sectoren de werknemers het meest te maken krijgen met nieuwe ontwikkelingen in de informatietechnologie.

Tabel 4.1

Technologische ontwikkelingen per bedrijfssector: informatisering, 1996

\begin{tabular}{lll}
\hline Bedrijfssector & $\%$ & typering \\
\hline & & \\
Landbouw en visserij & 15 & erg laag \\
Voeding & 42 & gemiddeld \\
Chemie & 70 & geog \\
Metaal en elektrotechniek & 46 & gemiddeld \\
Overige industrie & 53 & hoog \\
Energie & 78 & laag \\
Bouw en onroerend goed & 27 & gemiddeld \\
Handel & 50 & gemiddeld \\
Transport en communicatie & 50 & erg hoog \\
Bank- en verzekeringswezen & 95 & gemiddeld \\
Horeca, reparatie en zakelijke dienstverlening & 60 & gemiddeld \\
Kwartaire diensten & 47 & hoog \\
Overheid en onderwijs & 73 &
\end{tabular}

Bron: CBS/ROA 
Uit de tabel komt duidelijk naar voren dat de werkzaamheden in een aantal bedrijfssectoren sterk beïnvloed worden door het gebruik van informatietechnologie. Het gaat hierbij vooral om het bank- en verzekeringswezen, de overheids- en onderwijssector en de chemie. In de sectoren landbouw en visserij en bouw en onroerend goed is daarentegen veel minder sprake van een informatiseringsproces. In deze sectoren werkt respectievelijk slechts 15 en $27 \%$ van de werknemers vaak of soms met een computer.

\subsection{Organisatorische ontwikkelingen}

Niet alleen technologische, maar ook organisatorische ontwikkelingen doen een beroep op het aanpassingsvermogen en de inzetbaarheid van werknemers. Tegenwoordig wordt de organisatiestructuur steeds meer opgezet vanuit een behoefte aan flexibiliteit. De wat starre, sterk geformaliseerde organisatie van weleer maakt plaats voor een minder strakke organisatie, waar werknemers in projectgroepen werken en bovendien een redelijke mate van autonomie over hun eigen werkzaamheden hebben.

De indicator voor organisatorische ontwikkelingen is tot stand gekomen als combinatie van een tweetal kengetallen die wijzigingen in de organisatie belichten. Het gaat om het percentage bedrijven waarbij de positie ${ }^{1}$ van de organisatie is veranderd en het percentage organisaties waarbinnen er interne reorganisaties hebben plaatsgevonden. De samengestelde indicator wordt in tabel 4.2 gepresenteerd.

Tabel 4.2

Organisatorische ontwikkelingen per bedrijfssector: interne reorganisaties en veranderingen in de positie van het bedrijf, 1994

\begin{tabular}{lcl}
\hline Bedrijfssector & index & typering \\
\hline Landbouw en visserij & 33 & erg laag \\
Voeding & 42 & gemiddeld \\
Chemie & 38 & gemiddeld \\
Metaal en elektrotechniek & 76 & hoog \\
Overige industrie & 40 & gemiddeld \\
Energie & 94 & erg hoog \\
Bouw en onroerend goed & 35 & laag \\
Handel & 37 & laag \\
Transport en communicatie & 50 & gemiddeld \\
Bank- en verzekeringswezen & 30 & erg laag \\
Horeca, reparatie en zakelijke dienstverlening & 100 & erg hoog \\
Kwartaire diensten & 44 & gemiddeld \\
Overheid en Onderwijs & 61 & hoog \\
& & \\
\hline
\end{tabular}

${ }^{\star}$ Maximum $=100$

Bron:OSA/ROA

1. Met de positie wordt bedoeld de plaats van een organisatie in een groter geheel. Valt de organisatie bijvoorbeeld onder een holding; is het een dochteronderneming, een moedermaatschappij, etcetera. 
De snelste organisatorische ontwikkelingen vinden plaats in de sectoren horeca, reparatie en zakelijke dienstverlening en energie. Het valt op dat er ook in de sector overheid en onderwijs sprake is van snelle organisatorische ontwikkelingen. Het traditionele beeld van de overheid als een starre en bureaucratische organisatie, waar slechts zeer beperkt sprake is van organisatorische veranderingen, wordt hiermee enigszins ontkracht. Mogelijk zijn de grootschalige veranderingsprocessen in het onderwijs (klassenverkleining) een oorzaak voor de hoge index-score. Organisatorische ontwikkelingen zijn in het bank- en verzekeringswezen en de landbouw en visserij het minst van belang.

\subsection{Economische ontwikkelingen}

Ontwikkelingen in de concurrentie op de afzetmarkt van bedrijven zijn de belangrijkste economische ontwikkelingen die van invloed zijn op de behoefte aan employability. Daarbij kan in het bijzonder gedacht worden aan de 'globalisering' van de afzetmarkten. Om na te kunnen gaan in welke mate de diverse bedrijfssectoren bloot staan aan concurrentie, is de export van een sector gerelateerd aan de totale productie van de desbetreffende sector. De indicator geeft daarmee een beeld van de openheid van de sector. De indicator kan als proxy gezien worden van de concurrentie die de verschillende sectoren ondervinden in een globaliserende economie. Binnen de sectoren die het meest open zijn, zal de behoefte aan employability het grootst is.

De indicator heeft een hoge waarde wanneer het aandeel van de export in de productie hoog is, dat wil zeggen wanneer de sector in sterke mate geconfronteerd wordt met internationale concurrentie. In tabel 4.3 wordt de indicator gepresenteerd.

Tabel 4.3

Economische ontwikkelingen per bedrijfssector: mate van internationale concurrentie, 1996

\begin{tabular}{lll}
\hline Bedrijfssector & Index & typering \\
\hline & & \\
Landbouw en visserij & 0,48 & gemiddeld \\
Voeding & 0,53 & hoog \\
Chemie & 0,72 & erg hoog \\
Metaal en elektrotechniek & 0,58 & hoog \\
Overige industrie & 0,35 & gemiddeld \\
Energie & 0,34 & gemiddeld \\
Bouw en onroerend goed & 0,03 & erg laag \\
Handel & 0,07 & laag \\
Transport en communicatie & 0,33 & gemiddeld \\
Bank- en verzekeringswezen & 0,03 & erg laag \\
Horeca, reparatie en zakelijke dienstverlening & 0,04 & laag \\
Kwartaire diensten & 0,03 & erg laag \\
Overheid en onderwijs & 0,03 & erg laag \\
\end{tabular}

Bron: CBS/ROA 
De bedrijfssectoren voeding, chemie, en metaal en elektrotechniek zijn de sectoren die het meest open zijn. Voor die sectoren geldt dat ruim $50 \%$ van de productie bestemd is voor de export. Zoals te verwachten is, ondervinden de sectoren kwartaire diensten en overheid en onderwijs de minste internationale concurrentie. Binnen deze sectoren wordt voornamelijk gewerkt voor de nationale markt. Ook in de sectoren bouw en onroerend goed en bank- en verzekeringswezen is de internationale concurrentie minimaal.

\subsection{Demografische ontwikkelingen}

De demografische ontwikkelingen van het personeelsbestand in de verschillende bedrijfssectoren worden in kaart gebracht door het percentage oudere werknemers (50-64 jarigen) binnen een sector te delen door het percentage jongere werknemers (16-29 jarigen) binnen dezelfde sector. Deze indicator geeft aan in welke mate de vergrijzings- en ontgroeningstendensen in de bedrijfssectoren van belang zijn. Zoals reeds eerder naar voren kwam, is het werken aan de employability van oudere werknemers van groot belang, met name omdat het door de ontgroening van de werkzame beroepsbevolking voor organisaties steeds moeilijker wordt oudere werknemers door jongere te vervangen.

In het algemeen blijken oudere werknemers wat lager te scoren op de meeste employability-indicatoren uit hoofdstuk 3 . Bedrijfssectoren met een hoog aandeel oudere werknemers ten opzichte van het aandeel jongeren zouden daarom meer aandacht aan employability moeten besteden dan sectoren waarbij minder sprake is van ontgroening en vergrijzing. De indicator voor de demografische ontwikkelingen per bedrijfssector wordt gepresenteerd in tabel 4.4. De sectoren waarbinnen de demografische ontwikkelingen zich het sterkst manifesteren zijn de sectoren waarbinnen de behoefte aan werknemers met een hoge employability het grootst is.

Tabel 4.4

Demografische ontwikkelingen per bedrijfssector, percentage ouderen ten opzichte van het percentage jongeren, 1996-1997

\begin{tabular}{lll}
\hline Bedrijfssector & Index & typering \\
\hline & & hoog \\
Landbouw en visserij & 0,98 & laag \\
Voeding & 0,42 & hoog \\
Chemie & 0,83 & gemiddeld \\
Metaal en elektrotechniek & 0,66 & gemiddeld \\
Overige industrie & 0,62 & erg hoog \\
Energie & 1,97 & gemiddeld \\
Bouw en onroerend goed & 0,54 & erg laag \\
Handel & 0,33 & gemiddeld \\
Transport en communicatie & 0,61 & laag \\
Bank- en verzekeringswezen & 0,37 & erg laag \\
Horeca, reparatie en zakelijke dienstverlening & 0,34 & gemiddeld \\
Kwartaire diensten & 0,59 & erg hoog \\
Overheid en onderwijs & 1,32 & \\
\hline
\end{tabular}

Bron: CBS/ROA 
Uit tabel 4.4 blijkt dat met name in de sectoren energie en overheid en onderwijs sprake is van een relatief hoog percentage oudere werknemers. Het percentage oudere werknemers is binnen de sector energie zelfs twee keer zo hoog als het percentage jongere werknemers. De sectoren horeca, reparatie en zakelijke dienstverlening en handel zijn de minst vergrijsde sectoren. Het percentage jongere werknemers is in deze sectoren ongeveer drie maal zo hoog als het percentage oudere werknemers. Binnen deze sectoren is de behoefte aan employability vanuit deze invalshoek dan ook het minst groot.

\subsection{Employability behoefte per bedrijfssector}

De in dit hoofdstuk beschreven ontwikkelingen geven, zoals gezegd, tezamen een beeld van de behoefte aan employability in de diverse bedrijfssectoren. Om te komen tot een overkoepelende index van deze employability behoefte is de score voor iedere afzonderlijke indicator geïndexeerd. Vervolgens is per bedrijfssector de gemiddelde index vastgesteld. In tabel 4.5 wordt deze totaal-index gepresenteerd.

Tabel 4.5

Employability behoefte per bedrijfssector

\begin{tabular}{lrl}
\hline Bedrijfssector & Index & typering \\
\hline & & \\
Landbouw en visserij & 97 & laag \\
Voeding & 99 & gemiddeld \\
Chemie & 105 & hoog \\
Metaal en elektrotechniek & 104 & hoog \\
Overige industrie & 99 & gemiddeld \\
Energie & 113 & erg hoog \\
Bouw en onroerend goed & 92 & erg laag \\
Handel & 94 & laag \\
Transport en communicatie & 99 & gemiddeld \\
Bank- en verzekeringswezen & 98 & gemiddeld \\
Horeca, reparatie en zakelijke dienstverlening & 101 & gemiddeld \\
Kwartaire diensten & 96 & laag \\
Overheid en onderwijs & 103 & hoog \\
& & \\
\hline
\end{tabular}

Bron: ROA

Vanwege het feit dat alle beschreven ontwikkelingen in hoge mate van toepassing zijn op de sector energie, is de behoefte aan personeel met een hoge employability het grootst in deze sector. Ook in de chemiesector bestaat er een grote behoefte aan werknemers met een hoge employability. In deze bedrijfssector zijn drie van de vier onderscheiden maatschappelijke ontwikkelingen (uitzondering vormen de organisatorische ontwikkelingen) van groot belang. Op de derde plaats komen de sectoren metaal en elektrotechniek en overheid en onderwijs. In deze sectoren zijn het vooral de organisatorische en de demografische ontwikkelingen die ervoor zorgen dat er sprake is van een grote behoefte aan werknemers met een hoge employability. 
In de bedrijfssectoren handel en bouw en onroerend goed bestaat de geringste behoefte aan personeel met een hoge employability. In de sector bouw en onroerend goed spelen geen van de beschreven ontwikkelingen een grote rol. In de handel zijn alleen de technologische ontwikkelingen enigszins van belang. 


\section{Aanwezige en gevraagde employability}

\subsection{Inleiding}

De analyses uit de voorgaande twee hoofdstukken hebben twee kernindicatoren opgeleverd. In hoofdstuk 3 is de individuele employability van werknemers in de verschillende sectoren in een M.O.I. score uitgedrukt. Daarbij is gekeken naar drie bereidheids- en drie vermogensaspecten, die de employability van werknemers indiceren. Bovendien zijn voor enkele specifieke doelgroepen aparte M.O.I. scores berekend.

In hoofdstuk vier zijn vervolgens een aantal belangrijke ontwikkelingen die de bedrijfsvoering en de organisatie van de bedrijven in de sectoren beïnvloeden, in kaart gebracht. Het ging daarbij achtereenvolgens om de mate waarin de sector geconfronteerd wordt met technologische, organisatorische, economische en demografische ontwikkelingen. Deze ontwikkelingen zijn in belangrijke mate bepalend voor de behoefte aan werknemers met een hoge employability.

In dit hoofdstuk wordt de employability van de werknemers in de verschillende sectoren en de specifieke aandachtsgroepen vergeleken met de behoefte aan werknemers met een gunstige employability in de desbetreffende sector. Op die manier kan een beeld worden verkregen van de mate waarin de behoefte afgestemd is op de feitelijke employability van de werknemers.

De verdere planning van het hoofdstuk is als volgt. In paragraaf 5.2 wordt eerst per bedrijfssector de aanwezige employability van alle werknemers vergeleken met de behoefte aan werknemers met een gunstige employability. In de daaropvolgende paragrafen wordt hetzelfde gedaan voor vrouwen, jongeren, ouderen en laag opgeleiden. Paragraaf 5.7 vat de belangrijkste bevindingen van dit hoofdstuk nog eens kort samen.

\subsection{Aanbod van en behoefte aan employability: alle werknemers}

In tabel 5.1 is weergegeven in hoeverre per bedrijfssector wordt voorzien in de behoefte aan werknemers met een hoge employability. De resultaten zijn weergegeven in de vorm van een index. Uit de tabel blijkt dat met name in de sector bouw en onroerend goed de aanwezige employability relatief goed aansluit bij de behoefte. Ook binnen de sectoren handel en bank- en verzekeringswezen is de verhouding tussen de employability van de werknemers en de behoefte aan employability gunstig te noemen. Deze sectoren scoren hoog op de M.O.I.-index en relatief laag op de behoefte-index. De sectoren met de minst gunstige verhouding tussen de employability van de werknemers en de behoefte aan employability zijn transport en communicatie, energie en overheid en onderwijs. Deze sectoren scoren qua aanwezige 
employability relatief laag, terwijl er een relatief grote behoefte aan personeel met een hoge employability bestaat.

Tabel 5.1

Vergelijking aanbod en behoefte aan employability per bedrijfssector, alle werknemers

\begin{tabular}{lrl}
\hline Bedrijfssector & Index & typering \\
\hline & & \\
Landbouw en visserij & 100 & gemiddeld \\
Voeding & 103 & gemiddeld \\
Chemie & 97 & gemiddeld \\
Metaal en elektrotechniek & 97 & gemiddeld \\
Overige industrie & 102 & gemiddeld \\
Energie & 90 & erg laag \\
Bouw en onroerend goed & 110 & erg hoog \\
Handel & 107 & hoog \\
Transport en communicatie & 95 & laag \\
Bank- en verzekeringswezen & 105 & hoog \\
Horeca, reparatie en zakelijke dienstverlening & 102 & gemiddeld \\
Kwartaire diensten & 100 & gemiddeld \\
Overheid en onderwijs & 95 & laag \\
& & \\
\hline
\end{tabular}

Bron: ROA

\subsection{Aanbod van en behoefte aan employability: vrouwen}

In deze paragraaf zal worden gekeken naar de mate waarin de employability van de binnen de verschillende sectoren werkzame vrouwen aansluit bij de behoefte aan employability die binnen de desbetreffende sector bestaat.

Tabel 5.2

Vergelijking aanbod en behoefte aan employability per bedrijfssector, vrouwen

\begin{tabular}{lcl}
\hline & & \\
Bedrijfssector & Index & typering \\
\hline & & \\
Landbouw en visserij & 118 & erg hoog \\
Voeding & 106 & hoog \\
Chemie & 97 & gemiddeld \\
Metaal en elektrotechniek & 95 & laag \\
Overige industrie & 101 & gemiddeld \\
Energie & 101 & gemiddeld \\
Bouw en onroerend goed & 113 & erg hoog \\
Handel & 106 & hoog \\
Transport en communicatie & 91 & hoog \\
Bank- en verzekeringswezen & 109 & gemiddeld \\
Horeca, reparatie en zakelijke dienstverlening & 99 & gemiddeld \\
Kwartaire diensten & 97 & laag \\
Overheid en onderwijs & 93 &
\end{tabular}

\section{Bron: ROA}

Uit tabel 5.2 blijkt dat met name bij de vrouwen in de sector landbouw en visserij de employability gunstig afsteekt tegen de behoefte aan employability in de sector. De positie van de vrouwen in deze sector op de M.O.I.-index is relatief gunstig, terwijl 
de behoefte aan employability binnen de sector vrij gering is. Ook voor de sectoren bank- en verzekeringswezen en bouw en onroerend goed geldt dat de employability van vrouwen relatief goed aansluit bij de behoefte binnen die sectoren.

De sectoren waar de verhouding tussen de employability van de in de sector werkzame vrouwen en de behoefte aan employability het minst gunstig is, zijn transport en communicatie, overheid en onderwijs en metaal en elektrotechniek.

\subsection{Aanbod van en behoefte aan employability: jongeren}

In deze paragraaf worden de employability van de jongere werknemers en de behoefte aan employability per sector met elkaar geconfronteerd. Uit tabel 5.3 blijkt dat de vergelijking tussen de aanwezige en gevraagde employability voor jongeren het gunstigst uitvalt in de sectoren bank- en verzekeringswezen en handel. Binnen deze sectoren is de M.O.I. voor de jongere werknemers ten opzichte van de behoefte aan employability gunstig. Voor de sectoren landbouw en visserij en energie is de M.O.I.score lager dan de behoefte-index. Dit duidt er op dat voor jongeren in deze sectoren de aanwezige employability het minst goed aansluit bij de behoefte aan employability die binnen deze sectoren bestaat.

Tabel 5.3

Vergelijking aanbod en behoefte aan employability per bedrijfssector, jongeren

\begin{tabular}{lcl}
\hline Bedrijfssector & Index & typering \\
\hline & & \\
Landbouw en visserij & 98 & erg laag \\
Voeding & 114 & hoog \\
Chemie & 103 & laag \\
Metaal en elektrotechniek & 100 & erg laag \\
Overige industrie & 107 & gemiddeld \\
Energie & 102 & laag \\
Bouw en onroerend goed & 112 & hoog \\
Handel & 117 & hoog \\
Transport en communicatie & 107 & gemiddeld \\
Bank- en verzekeringswezen & 125 & erg hoog \\
Horeca, reparatie en zakelijke dienstverlening & 108 & gemiddeld \\
Kwartaire diensten & 107 & gemiddeld \\
Overheid en onderwijs & 108 & gemiddeld \\
& & \\
\hline Bron: ROA & &
\end{tabular}

Bron: ROA

\subsection{Aanbod van en behoefte aan employability: ouderen}

Tabel 5.4 geeft de verhouding aan tussen de feitelijke employability van de oudere werknemers en de behoefte aan employability per bedrijfssector. Uit de tabel blijkt dat de employability van de oudere werknemers in de meeste sectoren ongunstig afsteekt tegen de behoefte aan employability in de desbetreffende sector. Met name binnen de sectoren transport en communicatie en chemie is de employability van de oudere werknemers erg laag ten opzichte van de behoefte aan employability. De 
score op de behoefte-index overstijgt de score op de M.O.I.-index. Binnen de sectoren landbouw en visserij, bouw en onroerend goed en energie is de verhouding tussen de employability van de oudere werknemers en de behoefte aan employability een stuk gunstiger. In vergelijking met andere sectoren ligt voor oudere werknemers in deze sectoren de M.O.I.-score hoog ten opzichte van de bestaande behoefte. Opvallend is dat de verhouding tussen de feitelijke employability en de behoefte aan employability binnen de sector landbouw en visserij bij de oudere werknemers nogal verschilt van die bij de jongeren. Bij de ouderen overstijgt de feitelijke employability de behoefte, bij jongeren is dat juist omgekeerd.

Tabel 5.4

Vergelijking aanbod en behoefte aan employability per bedrijfssector, ouderen

\begin{tabular}{lrl}
\hline Bedrijfssector & Index & typering \\
\hline & & \\
Landbouw en visserij & 101 & erg hoog \\
Voeding & 94 & gemiddeld \\
Chemie & 82 & erg laag \\
Metaal en elektrotechniek & 89 & gemiddeld \\
Overige industrie & 92 & gemiddeld \\
Energie & 100 & hoog \\
Bouw en onroerend goed & 97 & hoog \\
Handel & 92 & gemiddeld \\
Transport en communicatie & 83 & gemiddeld \\
Bank- en verzekeringswezen & 93 & laag \\
Horeca, reparatie en zakelijke dienstverlening & 88 & gemiddeld \\
Kwartaire diensten & 90 & laag \\
Overheid en onderwijs & 88 &
\end{tabular}

\section{Bron: ROA}

\subsection{Aanbod van en behoefte aan employability: laag opgeleiden}

In deze paragraaf wordt voor laag opgeleiden de feitelijke employability geconfronteerd met de behoefte aan employability per bedrijfssector. Uit tabel 5.5 blijkt dat de confrontatie van het aanbod met de behoefte voor laag opgeleiden in de meeste sectoren ongunstig is. De employability van laag opgeleiden valt - afgezet tegen de behoefte aan employability - het gunstigst uit in de sectoren bouw en onroerend goed en handel. Voor de laag opgeleiden binnen deze sectoren geldt dat zij op de M.O.I.-index gunstiger scoren dan op de behoefte-index. Minder gunstig is de verhouding tussen de employability van de laag opgeleiden en de behoefte aan employability in de sectoren energie, chemie, transport en communicatie en voeding. Binnen deze sectoren is de feitelijke employability van laag opgeleiden ten opzichte van de behoefte aan employability het geringst. 
Tabel 5.5

Vergelijking aanbod en behoefte aan employability per bedrijfssector, laagopgeleiden

\begin{tabular}{lrl}
\hline Bedrijfssector & Index & typering \\
\hline & & \\
Landbouw en visserij & 96 & gemiddeld \\
Voeding & 93 & laag \\
Chemie & 92 & laag \\
Metaal en elektrotechniek & 94 & gemiddeld \\
Overige industrie & 100 & hoog \\
Energie & 86 & erg laag \\
Bouw en onroerend goed & 105 & erg hoog \\
Handel & 104 & hoog \\
Transport en communicatie & 93 & laag \\
Bank- en verzekeringswezen & 95 & gemiddeld \\
Horeca, reparatie en zakelijke dienstverlening & 96 & gemiddeld \\
Kwartaire diensten & 95 & gemiddeld \\
Overheid en onderwijs & 96 & gemiddeld \\
\end{tabular}

Bron: ROA

\subsection{Conclusies}

In deze laatste paragraaf passeren de belangrijkste conclusies die kunnen worden getrokken uit de confrontatie van de feitelijke employability van de werknemers binnen de diverse sectoren en de behoefte aan employability binnen de sectoren nog eens kort de revue. Met name de vier genoemde aandachtsgroepen komen hierbij aan de orde.

Een vergelijking van de diverse doelgroep-tabellen met tabel 5.1 levert een aantal interessante resultaten op. Allereerst valt voor de vrouwelijke werknemers op dat het zeker niet zo is dat zij qua employability in alle sectoren een slechtere positie innemen dan hun mannelijke collega's. In vijf van de dertien bedrijfssectoren is de verhouding tussen de aanwezige employability en de behoefte aan employability voor vrouwen zelfs gunstiger dan die voor mannen.

Wanneer de tabel voor de jongeren wordt vergeleken met die van de totale groep werknemers valt op dat jongeren niet, zoals misschien verwacht mocht worden, in elke sector een relatief gunstige verhouding tussen hun feitelijke employability en de sectorale employability behoefte hebben. In de sector landbouw en visserij bijvoorbeeld is deze verhouding voor jongeren een stuk minder gunstig dan voor de totale groep werknemers. De aansluiting van de aanwezige employability bij jongeren op de behoefte aan employability binnen de sector is echter wel in het merendeel van de sectoren relatief gunstig. In de sectoren handel en bank- en verzekeringswezen is de employability van jongeren in vergelijking met de behoefte vanuit de sector erg groot. In de sector landbouw en visserij is de verhouding tussen de feitelijke employability en de behoefte aan employability voor oudere werknemers gunstiger dan voor jongere werknemers. Dit kan op z'n minst opvallend worden genoemd. Oudere 
werknemers voorzien in dat geval kennelijk beter in de behoefte aan employability dan jongere werknemers.

Bij de laag opgeleiden valt op dat zij met name in de sector overheid en onderwijs gunstig scoren ten opzichte van hun hoger opgeleide collega's. Binnen deze sectoren is immers de score op de M.O.I.-index ten opzichte van de behoefte aan employability voor laag opgeleiden gunstiger dan voor de totale groep werknemers.

In dit hoofdstuk is aangegeven in hoeverre er binnen de verschillende sectoren discrepanties bestaan tussen de behoefte aan employability en de employability van het in de desbetreffende sector werkzame personeel. Op basis daarvan is bepaald in welke sectoren de meeste behoefte bestaat aan een verbetering van de employability van de werknemers. In het volgende hoofdstuk zal nu worden aangegeven in hoeverre er binnen de diverse sectoren mogelijkheden bestaan om de employability van de werknemers optimaal te benutten en verder te verbeteren. 


\section{Effectueringscondities per bedrijfssector}

\subsection{Inleiding}

In de voorgaande hoofdstukken zijn bedrijfssectoren gekarakteriseerd op basis van de feitelijke employability van de werknemers, uitgedrukt in de M.O.I. per sector en de behoefte aan employability, vastgesteld aan de hand van de doorwerking van bepaalde maatschappelijke ontwikkelingen binnen de desbetreffende sector. De confrontatie van deze resultaten leverde in het vorige hoofdstuk een indicatie op van de behoefte die er binnen sectoren bestaat aan employability-beleid. In dit hoofdstuk zal worden ingegaan op de inspanningen die binnen bedrijfssectoren worden gedaan om de behoefte aan employability in te vullen. Deze inspanningen worden, in navolging van Thijssen (1997), effectueringscondities genoemd.

Effectueringscondities zijn te omschrijven als de omstandigheden waaronder werknemers binnen organisaties tot een invulling en effectuering van hun individuele employability kunnen komen. Hierbij draait het met name om het employabilitybeleid dat binnen organisaties wordt gevoerd. Thijssen (1997) maakt een onderscheid tussen effectueringscondities van contextuele aard en effectueringscondities van persoonlijke aard. Onder effectueringscondities van contextuele aard vallen de arbeidsmarktsituatie, de loopbaanbegeleiding en bijvoorbeeld scholingsmogelijkheden. Effectueringscondities van persoonlijke aard hebben voornamelijk betrekking op de bereidheden en voorkeuren van individuele werknemers. In de hoofdstukken 2 en 3 is reeds uitvoerig aandacht besteed aan deze condities van persoonlijke aard, uitgedrukt in een individuele employability-score, de M.O.I.. In dit hoofdstuk staan daarom de effectueringscondities van contextuele aard centraal.

Allereerst wordt in paragraaf 6.2 weergegeven in hoeverre er binnen sectoren scholingsinspanningen worden geleverd. Hierbij wordt evenals in Werkgelegenheid en scholing 1997 uitgegaan van gegevens omtrent het percentage medewerkers in een sector dat momenteel een bedrijfsopleiding volgt. Paragraaf 6.3 beschrijft vervolgens de arbeidsmarktsituatie binnen de diverse sectoren. Dit gebeurt aan de hand van gegevens omtrent de verwachte uitbreidingsvraag. Aan de hand van de resultaten van deze beide analyses wordt in paragraaf 6.4 een indicator gegenereerd, die aangeeft in hoeverre er binnen de verschillende bedrijfssectoren aandacht wordt geschonken aan employability.

\subsection{Scholingsmogelijkheden per bedrijfssector}

Scholing staat centraal bij de ontwikkeling van employability van werknemers. Eerder in dit rapport werd al duidelijk dat de bereidheid en het vermogen van werknemers om opleidingen en cursussen te volgen als centrale indicatoren gelden voor de op een bepaald moment aanwezige individuele employability. Zonder daadwer- 
kelijke mogelijkheden om iets met de opleidingsbereidheid en het opleidingsvermogen te doen zijn deze beide kwaliteiten echter ontoereikend.

Organisaties bieden ter effectuering van de aanwezige opleidingsbereidheid en het opleidingsvermogen van hun werknemers veelal een pakket scholingsmogelijkheden aan hun personeel aan. Hiermee dienen organisaties in feite twee doelen. Enerzijds geven zij werknemers de mogelijkheid zich verder te ontwikkelen, waarmee zij in een behoefte van werknemers voorzien. Anderzijds breiden zij het in de organisatie aanwezige menselijk kapitaal uit, waardoor de positie van het bedrijf in de markt wordt versterkt, een behoefte van de organisatie zelf. Scholingsinspanningen dienen dus zowel de belangen van werkgevers als die van werknemers en vormen daarmee een belangrijke indicator bij de bepaling van de mogelijkheden voor werknemers hun employability te effectueren. Als immers bepaalde organisaties hun personeel weinig tot geen scholingskansen bieden dan wordt van het opleidingsvermogen en de opleidingsbereidheid van werknemers onvoldoende gebruik gemaakt. De aanwezige employability wordt niet goed onderhouden.

Om nu te bepalen in hoeverre er binnen bedrijfssectoren aandacht wordt geschonken aan de scholing en opleiding van werknemers is in deze paragraaf gekeken naar het gemiddelde percentage werknemers dat ten tijde van de enquêtering in 1995 en 1996 één of meerdere bedrijfsopleidingen volgde. Dit percentage geeft een indicatie van het aanbod van bedrijfsopleidingen binnen bedrijfssectoren en kan daarmee worden gezien als een indicator voor de actuele sectorale scholingsinspanning. Binnen de sectoren die worden gekenmerkt door een hoog percentage werknemers dat een bedrijfsopleiding volgt kan de aanwezige employability van werknemers goed worden geëffectueerd. Voor deze sectoren geldt dat er relatief veel wordt gedaan aan de employability van de werknemers. In tabel 6.1 is het gemiddelde percentage werknemers dat een bedrijfsopleiding volgt in kaart gebracht per bedrijfssector. Daarbij is ook een typering en een trend voor de laatste jaren weergegeven.

Uit tabel 6.1 blijkt dat met name de sectoren bank-verzekeringswezen en energie worden gekenmerkt door relatief veel scholingsinspanningen. De sector chemie is wat betreft scholing een sector die sterk in opkomst is, evenals de sector bouw en onroerend goed. Zowel de sector chemie als de sectoren bank- en verzekeringswezen en energie zijn sectoren waarbinnen veranderingen elkaar in snel tempo opvolgen (zie hoofdstuk 4). Om al deze veranderingen en ontwikkelingen het hoofd te bieden worden de werknemers in deze sectoren dus blijkbaar ook veel bijgeschoold. Met name de sector landbouw en visserij wordt gekenmerkt door geringe scholingsinspanningen. Wat tenslotte opvalt is dat het percentage werknemers dat bedrijfsopleidingen volgt in de sector bouw en onroerend goed een sterk stijgende trend vertoont. Dit duidt erop dat de aandacht voor scholing in deze sector toeneemt. 
Tabel 6.1

Scholingsinspanningen per bedrijfssector, gemiddelde percentage werkenden dat deelneemt aan bedrijfsopleidingen, 1995-1996

\begin{tabular}{|c|c|c|c|}
\hline Bedrijfssector & $\%$ & typering & trend \\
\hline Landbouw en visserij & 1 & erg laag & fluctuerend \\
\hline Voeding & 5 & gemiddeld & fluctuerend \\
\hline Chemie & 7 & hoog & sterk stijgend \\
\hline Metaal en elektrotechniek & 4 & gemiddeld & fluctuerend \\
\hline Overige industrie & 4 & gemiddeld & sterk dalend \\
\hline Energie & 11 & erg hoog & fluctuerend \\
\hline Bouw en onroerend goed & 6 & gemiddeld & sterk stijgend \\
\hline Handel & 3 & gemiddeld & fluctuerend \\
\hline Transport en communicatie & 3 & gemiddeld & fluctuerend \\
\hline Bank- en verzekeringswezen & 12 & erg hoog & fluctuerend \\
\hline $\begin{array}{l}\text { Horeca, reparatie en zakelijke dienst- } \\
\text { verlening }\end{array}$ & 3 & gemiddeld & fluctuerend \\
\hline Kwartaire diensten & 5 & gemiddeld & constant \\
\hline Overheid en onderwijs & 6 & gemiddeld & fluctuerend \\
\hline
\end{tabular}

Bron: $\mathrm{CBS} / \mathrm{ROA}$

\subsection{Uitbreidingsvraag per bedrijfssector}

Naast de scholingsinspanningen speelt ook de arbeidsmarktsituatie een grote rol bij de effectuering van de aanwezige employability. Bestaat er een grote mate van individuele employability in die zin dat werknemers bereid en in staat zijn een andere functie uit te gaan oefenen, maar is er sprake van een aanbodoverschot op het desbetreffende arbeidsmarktsegment, dan kan de aanwezige employability vaak niet of nauwelijks worden geëffectueerd. In deze paragraaf staat centraal in hoeverre er binnen bedrijfssectoren ruimte bestaat om naar een andere functie over te stappen. De mate waarin die overstap mogelijk is wordt geïndiceerd door de uitbreidingsvraag: de ontwikkeling van de werkgelegenheid in de desbetreffende bedrijfssector. Wordt een sector gekenmerkt door een positieve uitbreidingsvraag dan ontstaan er binnen die sector meer mogelijkheden voor werknemers om hun employability te effectueren dan bij een krimpende werkgelegenheid. Bij een toenemende werkgelegenheid wordt het voor werknemers bijvoorbeeld gemakkelijker een andere baan te vinden als ze hun huidige baan dreigen te verliezen. Maar ook het veranderen van functie zonder dat men daartoe min of meer gedwongen wordt, is gemakkelijker. In tabel 6.2 is de verwachte uitbreidingsvraag voor de komende jaren per bedrijfssector weergegeven.

Wat als eerste opvalt is dat in nagenoeg elke sector de uitbreidingsvraag positief is, dat wil zeggen dat de totale werkgelegenheid de komende jaren naar verwachting zal toenemen. Alleen in de sectoren landbouw en visserij en energie is naar verwachting sprake van een lichte krimp van de werkgelegenheid met respectievelijk $1 \%$ en $0,1 \%$ per jaar. Met name binnen de sector landbouw en visserij zijn de 
mogelijkheden voor werknemers om uiting te geven aan hun employability relatief gering. Naast deze beide sectoren is de uitbreidingsvraag binnen de sectoren banken verzekeringswezen en overheid en onderwijs ook relatief laag.

Tabel 6.2

Uitbreidingsvraag als percentage van het aantal werkenden per bedrijfssector 1997-2002, (gemiddelde jaarlijkse percentages)

\begin{tabular}{lcl}
\hline Bedrijfssector & $\%$ & typering \\
\hline Landbouw en visserij & $-1,0$ & erg laag \\
Voeding & 0,4 & laag \\
Chemie & 1,7 & gemiddeld \\
Metaal en elektrotechniek & 1,8 & gemiddeld \\
Overige industrie & 0,9 & gemiddeld \\
Energie & $-0,1$ & erg laag \\
Bouw en onroerend goed & 0,8 & gemiddeld \\
Handel & 2,2 & hoog \\
Transport en communicatie & 1,5 & gemiddeld \\
Bank- en verzekeringswezen & 0,4 & laag \\
Horeca, reparatie en zakelijke dienstverlening & 3,6 & erg hoog \\
Kwartaire diensten & 1,7 & gemiddeld \\
Overheid en onderwijs & 0,3 & laag \\
& & \\
\hline Bron: ROA
\end{tabular}

Bron: ROA

Van de overige sectoren is het de sector horeca, reparatie en zakelijke dienstverlening die de grootste groei laat zien met een jaarlijkse uitbreidingsvraag van maar liefst 3,6\%, gevolgd door de sector handel met een uitbreidingsvraag van $2,2 \%$ per jaar. Deze sectoren bieden derhalve de komende jaren de beste mogelijkheden voor werknemers om hun employability te effectueren c.q. verder te verbeteren.

\subsection{Effectueringscondities per bedrijfssector}

In deze paragraaf zal een samenvattend beeld worden gegeven van de mogelijkheden die er binnen de verschillende sectoren bestaan om de employability van werknemers te effectueren. Uitgangspunt vormen de scholingsinspanningen en de uitbreidingsvraag per sector. Wanneer binnen een sector een gunstige uitbreidingsvraag wordt gecombineerd met een grote scholingsinspanning is er binnen die betreffende sector sprake van gunstige effectueringscondities. Gunstige effectueringscondities binnen een sector duiden erop dat werknemers ruime mogelijkheden hebben hun employability te effectueren en verder te verbeteren. In tabel 6.3 is aangegeven binnen welke sectoren de effectueringscondities het meest gunstig zijn.

Uit tabel 6.3 blijkt dat vooral binnen de sector bank- en verzekeringswezen de omstandigheden om de employability van de werknemers te effectueren gunstig zijn. Met name wat betreft de scholingsmogelijkheden kwam deze sector als zeer aantrekkelijk naar voren. Om in te kunnen spelen op de automatisering van de productieprocessen binnen het bank- en verzekeringswezen en de omschakeling van 
administratieve naar commerciële functies is ook veel scholing nodig binnen deze sector (Zie ook ROA, 1998a). Behalve de sector bank- en verzekeringswezen is er ook binnen de sectoren, horeca, reparatie en zakelijke dienstverlening en chemie sprake van relatief gunstige effectueringscondities. In de sector horeca, reparatie en zakelijke dienstverlening zijn de effectueringscondities bijna even gunstig als die binnen de sector bank- en verzekeringswezen. In deze bedrijfssector zijn de effectueringscondities echter vooral gunstig als gevolg van de kansen die de werknemers worden geboden door de relatief grote uitbreidingsvraag.

Tabel 6.3

Effectueringscondities per bedrijfssector.

\begin{tabular}{lrl}
\hline Bedrijfssector & Index & typering \\
\hline Landbouw en visserij & 86 & erg laag \\
Voeding & 97 & laag \\
Chemie & 105 & hoog \\
Metaal en elektrotechniek & 101 & gemiddeld \\
Overige industrie & 98 & gemiddeld \\
Energie & 103 & hoog \\
Bouw en onroerend goed & 100 & gemiddeld \\
Handel & 100 & gemiddeld \\
Transport en communicatie & 98 & gemiddeld \\
Bank- en verzekeringswezen & 107 & erg hoog \\
Horeca, reparatie en zakelijke dienstverlening & 106 & erg hoog \\
Kwartaire diensten & 102 & hoog \\
Overheid en onderwijs & 97 & laag \\
\end{tabular}




\section{De Sectorale Employability Index}

\subsection{Inleiding}

In dit laatste hoofdstuk wordt de uiteindelijke index, die bepaald wordt aan de hand van de analyses in de vorige hoofdstukken, gepresenteerd. De eerste vier stappen die nodig waren om te komen tot deze Sectorale Employability Index zijn achtereenvolgens:

1 Het bepalen van de individuele employability van de werknemers per bedrijfssector (M.O.I. score);

2 Het analyseren van de ontwikkelingen die voor de bedrijven en organisaties in de bedrijfssectoren van belang zijn en op basis daarvan een behoefte-indicator bepalen;

3 Het confronteren van de M.O.I. score met de samengestelde indicator voor de ontwikkelingen in de sectoren, om te komen tot een index van de mate waarin de behoefte aan employability en de feitelijke employability van de werknemers in de verschillende sectoren op elkaar zijn afgestemd;

4 Het analyseren van de effectueringscondities.

In dit hoofdstuk wordt de laatste stap in de berekening van de S.E.I. gezet. Het gaat hier om een vergelijking van de in hoofdstuk 5 berekende verhouding tussen de M.O.I. en de employability behoefte enerzijds en de effectueringscondities uit het vorige hoofdstuk anderzijds (zie figuur 1.1). Uitgangspunt hierbij zijn steeds de scores van bedrijfssectoren op de verschillende onderdelen van de S.E.I. Heeft een sector ten opzichte van de andere sectoren een hoge M.O.I., een geringe behoefte aan employability en gunstige effectueringscondities, dan is de S.E.I.-score hoog. Naarmate een sector op een van deze drie elementen relatief slechter scoort is de score op de uiteindelijke S.E.I. ook minder gunstig. De Sectorale Employability Index is dus op te vatten als een index die de M.O.I., de behoefte aan employability en de effectueringscondities per bedrijfssector combineert.

In dit hoofdstuk wordt de S.E.I. voor de gehele werknemerspopulatie en per doelgroep gepresenteerd. Zoals reeds eerder is aangegeven, worden de verschillen in de S.E.I. tussen doelgroepen en de gehele werknemerspopulatie en de onderscheiden doelgroepen overigens uitsluitend veroorzaakt door verschillen in de gemiddelde M.O.I. scores. De ontwikkelingen die op de sector afkomen en de effectueringscondities zijn namelijk voor alle groepen werknemers in een bepaalde sector gelijk verondersteld. In paragraaf 7.2 zal de index voor alle werknemers gepresenteerd worden. In paragraaf 7.3 wordt er een S.E.I. toegespitst op de vrouwelijke werknemers gepresenteerd. De employability indices voor jongere en oudere werknemers komen daarna aan de orde in respectievelijk paragraaf 7.4 en 7.5 . In 
paragraaf 7.6 wordt er een S.E.I. voor laaggeschoolde werknemers gepresenteerd. Paragraaf 7.7 sluit het hoofdstuk af met enkele samenvattende conclusies.

\subsection{S.E.I. per bedrijfssector: alle werknemers}

De S.E.I. voor de totale werknemerspopulatie wordt in tabel 7.1 weergegeven. Uit tabel 7.1 blijkt dat de sector bank en verzekeringswezen het beste scoort op de index. In deze sector is de behoefte aan employability beperkt. De in hoofdstuk 4 beschreven ontwikkelingen hebben geen grote invloed op de sector. In combinatie met de gemiddelde M.O.I. score van de werknemers en de gemiddelde score voor de effectueringscondities leidt dit ertoe, dat de employability van de werknemers in de sector goed is. Bovendien kan de employability van de werknemers in deze sector goed worden geëffectueerd en verder worden verbeterd vanwege de relatief gunstige effectueringscondities. De werknemers in de sectoren bouw en onroerend goed en horeca, reparatie en zakelijke dienstverlening komen qua employability op de tweede en derde plaats. In de laatstgenoemde spelen de in kaart gebrachte maatschappelijke ontwikkelingen wel een relatief grote rol. Met name de informatiseringstendensen leiden ertoe dat de employability van de werknemers in deze sectoren van groot belang is.

Tabel 7.1

Sectorale Employability Index, alle werknemers*

\begin{tabular}{lrrrr}
\hline Bedrijfssector & S.E.I. & M.O.I. & EB & EC \\
& & & & \\
\hline & & & & \\
Bank- en verzekeringswezen & 112 & 103 & 98 & 107 \\
Bouw en onroerend goed & 109 & 101 & 92 & 100 \\
Horeca, reparatie en zakelijke dienstverlening & 109 & 103 & 101 & 106 \\
Handel & 107 & 100 & 94 & 100 \\
Chemie & 102 & 102 & 105 & 105 \\
Kwartaire diensten & 102 & 96 & 96 & 102 \\
Voeding & 100 & 101 & 99 & 97 \\
Overige industrie & 100 & 101 & 99 & 98 \\
Metaal en elektrotechniek & 97 & 100 & 104 & 101 \\
Energie & 93 & 102 & 113 & 103 \\
Overheid en onderwijs & 93 & 99 & 103 & 97 \\
Transport en communicatie & 93 & 94 & 99 & 98 \\
Landbouw en visserij & 86 & 97 & 97 & 86 \\
\end{tabular}

* S.E.I. = Sectorale Employability Index; M.O.I. = Index Mobiliteit, Opleiding en Inzetbaarheid; $\mathrm{EB}=$ Employabilitybehoefte; $\mathrm{EC}=$ Effectueringscondities. Bron: ROA

De sector die het slechtst scoort op de S.E.I. is landbouw en visserij. In deze sector zijn vooral de slechte effectueringscondities verantwoordelijk voor de lage S.E.I.score. In de energiesector zijn vooral de lage individuele employability van de werknemers en de grote behoefte aan werknemers met een hoge employability vanwege organisatorische, technologische en demografische ontwikkelingen verantwoordelijk voor de vrij lage positie op de index. In de sector transport en communicatie beïn- 
vloedt vooral de geringe individuele employability van de werknemers de S.E.I.score ongunstig. In iets mindere mate geldt dit ook voor de sector overheid en onderwijs. In deze sector zijn bovendien de effectueringscondities relatief ongunstig.

\subsection{S.E.I. per bedrijfssector: vrouwen}

De verdeling van de werkgelegenheid naar geslacht verschilt sterk per bedrijfssector, beroep, en opleidingstype (zie ROA, 1997a/b). Aangezien vrouwen vaak werkzaam zijn in 'vrouwenberoepen' en bovendien vaak een opleidingsachtergrond hebben die afwijkt van die van hun mannelijke collega's zou het kunnen dat de employability van vrouwelijke werknemers per sector afwijkt van de employability van de mannen. In de volgende tabel wordt de S.E.I. per bedrijfssector voor alleen de vrouwelijke werknemers gepresenteerd.

Tabel 7.2

Sectorale Employability Index, vrouwen*

\begin{tabular}{lrrrr}
\hline Bedrijfssector & S.E.I. & M.O.I. & EB & EC \\
& & & & \\
\hline & & & & \\
Bank- en verzekeringswezen & 116 & 107 & 98 & 107 \\
Bouw en onroerend goed & 113 & 104 & 92 & 100 \\
Handel & 106 & 99 & 94 & 100 \\
Horeca, reparatie en zakelijke dienstverlening & 106 & 101 & 101 & 106 \\
Energie & 104 & 114 & 113 & 103 \\
Chemie & 102 & 101 & 105 & 105 \\
Voeding & 102 & 104 & 99 & 97 \\
Landbouw en visserij & 101 & 115 & 97 & 86 \\
Kwartaire diensten & 100 & 93 & 96 & 102 \\
Overige industrie & 99 & 100 & 99 & 98 \\
Metaal en elektrotechniek & 96 & 99 & 104 & 101 \\
Overheid en onderwijs & 91 & 96 & 103 & 97 \\
Transport en communicatie & 89 & 90 & 99 & 98 \\
& & & & \\
\hline
\end{tabular}

* zie noot tabel 7.1

Bron: ROA

Uit de tabel komt naar voren dat de verschillen tussen de gehele werknemerspopulatie en de vrouwelijke werknemers op zich klein zijn. Ook voor vrouwen geldt, dat de employability het grootst is in de sectoren bank- en verzekeringswezen en bouw en onroerend goed. De sector bank- en verzekeringswezen scoort het beste. Dit heeft deze sector met name te danken aan de relatief geringe behoefte aan werknemers met een hoge employability ten opzichte van de aanwezige employability en aan de gunstige effectueringscondities. In deze sector is de individuele employability van het vrouwelijk personeel overigens nog gunstiger dan gemiddeld. De sector transport en communicatie scoort ook onder vrouwen het slechtst. Deze sector combineert een geringe aanwezige employability met een relatief grote behoefte. Daarbij zijn de effectueringscondities vrij ongunstig. In deze sector is de individuele employability van de vrouwelijke werknemers overigens nog slechter dan de 
gemiddelde employability van de werknemers in de sector. Er zijn enkele sectoren waarvoor geldt dat zij op de S.E.I. een hogere positie op de index innemen als alleen naar vrouwelijke werknemers wordt gekeken. Het gaat dan bijvoorbeeld om de sectoren landbouw en visserij en energie.

\subsection{S.E.I. per bedrijfssector: jongeren}

Uit de analyse in hoofdstuk 3 bleek al dat jongere werknemers in het algemeen op het merendeel van de onderscheiden aspecten van de individuele employability beter scoren dan andere werknemers. Dit zou kunnen betekenen dat de S.E.I. voor jongere werknemers in bijna alle sectoren op een hoger niveau ligt dan de S.E.I. voor alle werknemers.

Tabel 7.3

Sectorale Employability Index, jongeren*

\begin{tabular}{lrrrr}
\hline Bedrijfssector & S.E.I. & M.O.I. & EB & EC \\
\hline Bank- en verzekeringswezen & & & & \\
Handel & 133 & 122 & 98 & 107 \\
Horeca, reparatie en zakelijke dienstverlening & 118 & 110 & 94 & 100 \\
Bouw en onroerend goed & 115 & 110 & 101 & 106 \\
Voeding & 112 & 103 & 92 & 100 \\
Kwartaire diensten & 110 & 112 & 99 & 97 \\
Chemie & 109 & 102 & 96 & 102 \\
Overige industrie & 108 & 108 & 105 & 105 \\
Energie & 105 & 106 & 99 & 98 \\
Overheid en onderwijs & 105 & 115 & 113 & 103 \\
Transport en communicatie & 105 & 112 & 103 & 97 \\
Metaal en elektrotechniek & 104 & 106 & 99 & 98 \\
Landbouw en visserij & 101 & 104 & 104 & 101 \\
& 84 & 95 & 97 & 86 \\
\hline
\end{tabular}

* zie noot tabel 7.1

Bron: ROA

Tabel 7.3 geeft een overzicht van de S.E.I. voor jongeren per bedrijfssector. De sector met de voor jongere werknemers hoogste S.E.I. is het bank- en verzekeringswezen. Het zijn met name de employability indicatoren mobiliteitsvermogen, opleidingsbereidheid en opleidingsvermogen die er voor zorgen dat deze sector zeer hoog scoort voor wat betreft de employability van jongere werknemers. De sectoren handel en horeca, reparatie en zakelijke dienstverlening volgen de sector bank- en verzekeringswezen op enige afstand. Met name op het punt van de individuele employability van de jongeren blijven deze sectoren iets achter. De sector landbouw en visserij scoort het slechtst. De aanwezige employability is in deze sector niet voldoende om in de bestaande behoefte te voorzien. Bovendien zijn de effectueringscondities erg ongunstig, waardoor de mogelijkheden om de employability te effectueren c.q. te verbeteren, gering zijn. Ook de sectoren transport en communicatie en metaal en elektrotechniek scoren relatief ongunstig voor jongeren, met 
name omdat de individuele employability van de jongeren die werkzaam zijn in deze sectoren achterblijft bij die van de jongeren die in de andere sectoren werken.

Sectoren die op het punt van de employability van jonge werknemers beter scoren dan op de employability van het hele werknemersbestand zijn de sectoren handel, energie en voeding.

\subsection{S.E.I. per bedrijfssector: ouderen}

Tabel 7.4 geeft een overzicht van de S.E.I. per sector voor de oudere werknemers. Een vergelijking met tabel 7.3 geeft duidelijk aan dat de S.E.I. van de oudere werknemers op een veel lager niveau ligt dan de S.E.I. van de jongere werknemers. De sector met de meest gunstige employability voor ouderen is de sector energie. Binnen deze sector wordt een hoge individuele employability van de oudere werknemers gecombineerd met een grote behoefte. Omdat de effectueringscondities daarbij relatief gunstig zijn scoort de sector energie erg goed op de index. De sectoren bank- en verzekeringswezen en bouw en onroerend goed doen het ten aanzien van de employability van de oudere werknemers ook erg goed. In het bank en verzekeringswezen zijn de effectueringscondities erg gunstig. Voor de sector bouw en onroerend goed komt de gunstige S.E.I. vooral op rekening van de relatief geringe behoefte aan werknemers met een hoge employability. De sectoren waar de S.E.I. voor ouderen sterk achterblijft, zijn transport en communicatie, overheid en onderwijs en chemie. In de sector transport en communicatie is de S.E.I. voor oudere werknemers het laagst, met name vanwege de relatief slechte individuele

Tabel 7.4

Sectorale Employability Index, ouderen*

\begin{tabular}{lrrrr}
\hline Bedrijfssector & S.E.I. & M.O.I. & EB & EC \\
\hline Energie & & & & \\
Bank- en verzekeringswezen & 103 & 113 & 113 & 103 \\
Bouw en onroerend goed & 99 & 91 & 98 & 107 \\
Horeca, reparatie en zakelijke dienstverlening & 96 & 89 & 92 & 100 \\
Kwartaire diensten & 93 & 89 & 101 & 106 \\
Handel & 92 & 86 & 96 & 102 \\
Voeding & 92 & 86 & 94 & 100 \\
Metaal en elektrotechniek & 91 & 92 & 99 & 97 \\
Overige industrie & 90 & 92 & 104 & 101 \\
Landbouw en visserij & 90 & 91 & 99 & 98 \\
Chemie & 87 & 98 & 97 & 86 \\
Overheid en onderwijs & 86 & 85 & 105 & 105 \\
Transport en communicatie & 85 & 91 & 103 & 97 \\
& 81 & 82 & 99 & 98 \\
\hline
\end{tabular}

* zie noot tabel 7.1

Bron: ROA

employability van de oudere werknemers in deze sector. In de sectoren chemie en overheid en onderwijs is er een vrij grote behoefte aan employability. Oudere werk- 
nemers voldoen onvoldoende aan deze behoefte. Bij de sector overheid en onderwijs zijn bovendien de effectueringscondities ongunstig. Voorts valt op dat de sector chemie het onder ouderen heel wat slechter doet dan onder de gehele groep werknemers, een tiende respectievelijk vijfde plaats op de S.E.I. Dit betekent dat de employability onder ouderen in deze sector sterk achterblijft bij die van de oudere werknemers in andere sectoren.

\subsection{S.E.I. per bedrijfssector: laag opgeleiden}

In tabel 7.5 wordt de S.E.I. voor laag opgeleide werknemers weergegeven. Net als bij de S.E.I. voor de gehele werknemerspopulatie scoren de sectoren handel, bouw en onroerend goed, bank- en verzekeringswezen en horeca, reparatie en zakelijke dienstverlening het best terwijl de sector landbouw en visserij op de laatste plaats staat. De sector handel wint het van de overige sectoren doordat de laag opgeleiden in die sector een relatief grote individuele employability aan de dag leggen. Samen met de sector bouw en onroerend goed is handel de enige sector waar de aanwezige employability bij de laagopgeleiden de behoefte overstijgt. Gezien de redelijk gunstige effectueringscondities staan beide sectoren er relatief goed voor wat betreft employability van laag opgeleiden.

Tabel 7.5

Sectorale Employability Index, laag opgeleiden*

\begin{tabular}{|c|c|c|c|c|}
\hline Bedrijfssector & S.E.I. & M.O.I. & EB & $\mathrm{EC}$ \\
\hline Handel & 105 & 98 & 94 & 100 \\
\hline Bouw en onroerend goed & 104 & 97 & 92 & 100 \\
\hline Horeca, reparatie en zakelijke dienstverlening & 102 & 97 & 101 & 106 \\
\hline Bank- en verzekeringswezen & 101 & 93 & 98 & 107 \\
\hline Overige industrie & 98 & 99 & 99 & 98 \\
\hline Kwartaire diensten & 97 & 90 & 96 & 102 \\
\hline Chemie & 96 & 96 & 105 & 105 \\
\hline Metaal en elektrotechniek & 95 & 98 & 104 & 101 \\
\hline Overheid en onderwijs & 94 & 99 & 103 & 97 \\
\hline Transport en communicatie & 91 & 92 & 99 & 98 \\
\hline Voeding & 90 & 91 & 99 & 97 \\
\hline Energie & 89 & 97 & 113 & 103 \\
\hline Landbouw en visserij & 83 & 93 & 97 & 86 \\
\hline
\end{tabular}

* zie noot tabel 7.1

Bron: ROA

In de sector landbouw en visserij wordt een geringe employability van de laag opgeleiden gecombineerd met een grotere behoefte en relatief ongunstige effectueringscondities. Voor laag opgeleiden is deze sector dus de minst perspectiefrijke. Wat ook opvalt is de relatief lage positionering van de sector voeding. Voor de gehele groep werknemers deed deze sector het nog redelijk met een zevende plek, voor laag opgeleiden staat de sector voeding slechts op de elfde plaats doordat de individuele employability van de laag opgeleiden duidelijk achterblijft bij die van de 
andere werknemers in deze sector. De positie van de sector overheid en onderwijs is voor laag opgeleiden daarentegen gunstiger dan voor de gehele groep werknemers, doordat de individuele employability van de laag opgeleiden in deze sector niet achterblijft bij die van de andere werknemers in de sector, hetgeen in alle andere sectoren wel het geval is.

\subsection{Conclusies}

In dit hoofdstuk is de uiteindelijke Sectorale Employability Index gepresenteerd voor dertien bedrijfssectoren. De index geeft aan binnen welke sectoren de employability van de werknemers relatief goed is en binnen welke sectoren dat minder het geval is. Hierbij is niet alleen gekeken naar de actuele employability van de in een sector werkzame mensen, maar ook naar de behoefte die de verschillende bedrijfssectoren hebben aan werknemers met een hoge employability. Ten slotte is naar de effectueringscondities voor het employability beleid in de verschillende sectoren gekeken om een idee te krijgen van de mate waarin de employability van de werknemers binnen sectoren gerealiseerd en verder verbeterd kan worden. Deze elementen bepalen in combinatie met elkaar de positie van bedrijfssectoren op de Sectorale Employability Index.

De sector bank- en verzekeringswezen, de sector die bovenaan staat op de S.E.I., neemt bij de M.O.I.-index eveneens een eerste positie in; bij de behoefte-index staat de sector op de negende plaats en qua effectueringscondities staat de sector weer op een eerste plaats. In deze sector is relatief weinig behoefte aan employability. De kans dat de employability van de werknemers in deze sector tekort schiet is dus relatief gering. Bovendien zijn de effectueringscondities in deze sector erg gunstig waardoor er doorgaans waarschijnlijk goed op de employability behoefte kan worden ingespeeld. Dit maakt de sector bank- en verzekeringswezen tot de sector met de meest gunstige employability.

De sector bouw en onroerend goed staat in de S.E.I. op een tweede plaats. Deze sector scoort een gedeelde vijfde plaats op de M.O.I.-index. Op de behoefte-index scoort de sector bouw en onroerend goed het laagst. Er is dus net als in de sector bank- en verzekeringswezen sprake van een relatief hoge individuele employability van de in de sector werkzame werknemers in combinatie met een relatief geringe employability behoefte. Dit betekent dat er in vergelijking met andere sectoren goed in de bestaande behoefte wordt voorzien. De effectueringscondities binnen de sector bouw en onroerend goed zijn bovendien relatief gunstig.

De sector landbouw en visserij scoort vrij laag op de S.E.I. Het is deze sector waar het employability-klimaat het ongunstigst is. De individuele employability van de werknemers binnen de sector landbouw en visserij is relatief gering, zo blijkt uit de M.O.I.-index. De behoefte aan employability is weliswaar even gering, maar doordat 
daarbij de effectueringscondities relatief ongunstig zijn en de mogelijkheden om de employability te ontwikkelen derhalve beperkt zijn, neemt deze sector de laatste plaats in op de S.E.I.

In de sector energie is de behoefte aan employability het grootst, de bij de werknemers aanwezige employability is ook relatief groot. Omdat de behoefte aan employability in deze sector zo groot is, is het van groot belang dat er binnen de sector gunstige effectueringscondities bestaan om in die behoefte te blijven voorzien. De effectueringscondities binnen de sector energie zijn echter niet bijzonder gunstig, wat leidt tot een lage plaats op de Sectorale Employability Index. Opvallend hierbij is dat de sector energie bij de S.E.I. voor oudere werknemers als beste sector naar voren komt. Oudere werknemers in de sector energie blijken een erg grote individuele employability te hebben ten opzichte van oudere werknemers die werkzaam zijn in andere sectoren.

Als wordt gekeken naar de S.E.I. voor de vijf onderscheiden doelgroepen wordt duidelijk dat de top vier van bedrijfssectoren met de hoogste S.E.I. over het algemeen dezelfde is. Zowel voor vrouwen als voor jongeren als voor laag opgeleiden staan de sectoren bouw en onroerend goed, bank- en verzekeringswezen, handel en horeca, reparatie en zakelijke dienstverlening bovenaan. Voor ouderen geldt, zoals gezegd, dat de sector energie bovenaan de index staat, daarna volgen echter ook de vier hierboven genoemde sectoren. Wat betreft de staart van de index zijn er meer wisselingen. Voor vrouwen en ouderen scoort de sector transport en communicatie het slechtst, voor jongeren en laag opgeleiden is dat de sector landbouw en visserij. 


\section{Literatuur}

Bakker, P.A.H. en Th. J. van der Heijden, (1997), Inzetbaarheid meten en bevorderen, Gids voor Personeelsmanagement, nr. 5, pp. 43-45.

Bartel, A.P. en F.R. Lichtenberg (1987), The Comparative Advantage of implementing New Technology, Review of Economics and Statistics, vol. 69, no. 1, pp. 1-11.

Bélanger, P., en Falgàs, R.M. (1997), Adult Education and Aging, Trends and Critical Issues. Adult Education and Development, 49, pp.161-164.

Boerlijst, J.G. e.a. (1994), Veertigplussers in de onderneming, Assen: Van Gorcum.

Bolhuis, S. (1995), Leren en veranderen bij volwassenen: een nieuwe benadering. Bussum: Coutinho.

Bolweg, J.F. en G. van Beckhoven, (1995), Employability, een nieuw doel voor de P\&Ofunctie? Gids voor Personeelsmanagement, nr. 12, pp.55-57.

Bolweg, J.F. en J.M.M. Maenhout, (1995), Full employability: economisch noodzakelijk, sociologisch naïef?: In: L. Faase, M.Ott en C.J. Voss (red.), Nieuwe breukvlakken in het arbeidsbestel? pp.92-99. Utrecht: De Tijdstroom.

Brook Street (1990), Ageism: the problem of the 1990's: a survey of personnel directors and employees carried out on behalf of Brook Street by Gallup, London: Brook Street.

CBS/CPB (1997), Bevolking en arbeidsaanbod: drie scenario's tot 2020, Den Haag: SDU Uitgevers.

Cörvers, F. (1997), The Impact of human capital on labour productivity in manufacturing sectors of the European Union, in: Applied Economics, vol. 29, pp. 975-987.

Dalen, H.P. van (1993), De oudere werknemer: van generlei waarde? Economisch Statistische Berichten, jaargang 78, nr. 3911, pp. 448-453.

Delmee, J., A. de Grip en R. Welters (1998), De arbeidsmarktpositie van de kwartaire sector in een globaliserende omgeving, OSA-werkdocument W159, Den Haag.

Dosi, G., K. Pavitt en L. Soete (1990), The economics of technical change and international trade, New York: Harvester Wheatsheaf.

Europese commissie (1993), Growth, Competitiveness, Employment: the challenges and ways forward to the 21st century, Bulletin van de Europese Gemeenschap, Supplement 6/1993. Luxemburg: Office for Official Publications of the European Communities.

Gaspersz, J. en M. Ott, (1996), Management van employability. Nieuwe kansen in arbeidsrelaties. Assen: Van Gorcum.

Geuns van, A.K. en P.J. Platje, (1995), Vastgeroest, een probleem voor werkgever en werknemer, Gids voor Personeelsmanagement, nr. 10, pp. 54-60.

Grip de, A. en J. Hoevenberg (1996), Upgrading in the European Union, ROA-RM-1996/3E, Maastricht.

Grip, A., M. Van Smoorenburg, L. Borghans en N. Jonker, (1997a), Werkgelegenheid en scholing 1996, ROA/R-1997/1, Maastricht.

Grip, A., M. Van Smoorenburg, L. Borghans en N. Jonker, (1997b), Werkgelegenheid en scholing 1996, Statistische bijlage, ROA/R-1997, Maastricht.

Hirsch, F. (1977), Social limits to growth. London: Routledge and Regan Paul.

Jacobs, D. cs. (1990), De Economische kracht van Nederland: TNO-Beleidsstudies. 
Kalbfleisch, J. en R.L. Prentice (1980), The Statistical Analysis of Failure Time Data, New York: Wiley.

Kruidenier, H. en G. Manchia, (1998), Naar een effectief mobiliteitsbeleid: vergrijzing, verstarring, demotivatie, Gids voor Personeelsmanagement, nr. 5, pp. 18-22.

Machin, S., A. Ryan en J. van Reenan (1996), Technology and changes in skill structure: evidence from an international panel of industries, CEPR Discussion Paper No. 297.

Maroy, C. en M.B. Fusulier (1995), Modernisation des enterprises et formation des salariés, op internet: $h$ ttp://www.belspo.be/fedra/res/nl/ssd108.htm.

Nelson, R.R. en E.S. Phelps (1966), Investment in Human Capital, technological diffusion, and economic growth, American Economic Review, vol. 65, no. 2, pp. 69-75.

Porter, M. (1990), The Competitive advantage of nations, Londen: MacMillan.

ROA (1997a), De arbeidsmarkt naar opleiding en beroep tot 2002, ROA-R1997/7, Maastricht.

ROA (1997b), De arbeidsmarkt naar opleiding en beroep tot 2002, Statistische Bijlage, ROA-R1997/7B, Maastricht.

ROA (1998a), Werkgelegenheid en scholing 1997, ROA-R-1998/1, Maastricht.

ROA (1998b), Werkgelegenheid en scholing 1997, Statistische Bijlage, ROA-R-1998/1b, Maastricht.

Singerling, E.P.J. en H.J.M. Mes, (1994), Stapsgewijze analyse van employability, Gids voor Personeelsmanagement, nr. 12, pp. 35-40.

Thierry, Hk., (1977), Ploegenarbeid en de biologische klok op het werk, Deventer: van Loghum Slaterus.

Thijssen, J.G.L. (1996), Leren, leeftijd en loopbaanperspectief, Deventer: Kluwer Bedrijfs wetenschappen.

Thijssen, J.G.L. (1997), Employability en employment: terminologie, modelvorming en opleidingspraktijk, Opleiding en ontwikkeling 1997, nr 10, pp. 9-14.

Tooren, E.J., C.P.M. Kouwenhoven en E.P.J. Singerling (1996), Ken- en stuurgetallen Personeelsmanagement 1996, Gids voor Personeelsmanagement, no. 9, pp. 43-46.

Ultee, W. (1978), Is onderwijs een positioneel goed? Een empirische beproeving van alternatieve hypothesen over de samenhang tussen onderwijs en beroepshoogte. In: J. Peschar en W. Ultee (Red.), Sociale stratificatie (pp.83-102), Deventer: Van Loghum Slaterus.

Vliet van, G.E. (1997) Employability: Noodzaak en kansen, bijdrage aan congres Employability, werken aan wendbare en weerbare medewerkers, 28 januari 1997.

Wolbers, M.H.J. (1998), Diploma-inflatie en verdringing op de arbeidsmarkt; een studie naar ontwikkelingen in de opbrengsten van diploma's in Nederland, Proefschrift K.U.N., Nijmegen.

Wood, A. (1995), North-South Trade, Employment and Inequality, IDS Development Studies Series, Oxford, Clarendon Press. 


\section{Bijlage: Berekening S.E.I.}

In deze bijlage wordt een overzicht gegeven van de methodiek die gebruikt is om de S.E.I. te berekenen. Er wordt eerst ingegaan op de berekeningen die ten grondslag liggen aan de afzonderlijke elementen die de S.E.I. bepalen. Daarna komt de berekening van de S.E.I. zelf aan de orde.

Berekening M.O.I. (hoofdstuk 3)

De M.O.I. indicator geeft per doelgroep een beeld van de employability van de werknemers in een bedrijfssector. Daartoe worden 6 employability indicatoren gemiddeld, te weten: mobiliteitsvermogen, mobiliteitsbereidheid, opleidingsvermogen, opleidingsbereidheid, vermogen tot brede inzetbaarheid en bereidheid tot brede inzetbaarheid. Om de vergelijking tussen bedrijfssectoren en doelgroepen mogelijk te maken zijn de zes indicatoren eerst genormaliseerd en gestandaardiseerd. Dit gebeurt voor alle employability-indicatoren op dezelfde wijze. Zo komt de indicator voor het mobiliteitsvermogen $\left(M V_{i d}\right)$ in een bepaalde bedrijfssector voor een bepaalde doelgroep op de volgende wijze tot stand:

$M V_{i d}=100^{*}\left[\frac{M V_{i d}^{N}}{\overline{M V_{d}^{N}}}\right]$ waarbij

$M V_{i d}^{N}=\left[\frac{W M V_{i d}-\overline{W M V}_{d}}{s d\left(W M V_{d}\right)}\right]-M_{i d} N\left(\frac{W M V_{i d}-\overline{W M V}_{d}}{s d\left(W M V_{d}\right)}\right)+10$

$W M Y_{d} \quad=\quad$ het percentage werknemers uit doelgroep $d$ in bedrijfssector $i$ dat het vermogen heeft mobiel te zijn;

$\overline{W M V}_{d} \quad=$ het bedrijfssector-gemiddelde van $W M V_{i d}$;

$s d\left(W M V_{d}\right)=$ de standaardafwijking per doelgroep van het mobililiteitsvermogen per bedrijfssector.

Er ontstaat op die manier voor iedere doelgroep $d$ en iedere bedrijfssector $i$ een score voor het mobiliteitsvermogen. De tweede term de tweede in vergelijking zorgt ervoor dat de scores voor het mobiliteitsvermogen tussen de verschillende doelgroepen vergelijkbaar zijn. De overige vijf employability-indicatoren worden op analoge wijze berekend en vervolgens samen met het mobiliteitsvermogen gecombineerd tot de M.O.I indicator:

$M O I_{i d}=\frac{M V_{i d}+M B_{i d}+O V_{i d}+O B_{i d}+I V_{i d}+I B_{i d}}{6}$ 
De behoefte aan employability wordt bepaald aan de hand van de mate waarin vier ontwikkelingen in de bedrijfssectoren plaatsvinden, te weten: technologische, organisatorische, demografische en economische ontwikkelingen. De berekening vindt weer plaats door eerst een normalisatie en standaardisatie van de afzonderlijke indicatoren door te voeren en vervolgens de vier indicatoren te middelen zodat een indicator per bedrijfssector resulteert. Bij het vaststellen van de employability behoefte worden er geen afzonderlijke indicatoren voor de in het rapport onderscheiden doelgroepen berekend. De berekening van de indicator voor de technologische ontwikkelingen $\left(\mathrm{TO}_{i}\right)$ komt als volgt tot stand:

$$
\begin{aligned}
& T O_{i}=100^{*}\left[\frac{T O_{i}^{N}}{T O^{N}}\right] \text { waarbij } \\
& T O_{i}^{N}=\left[\frac{W T O_{i}-\overline{W T O}}{s d(W T O)}\right]-M_{i} N\left(\frac{W T O_{i}-W T O}{s d(W T O)}\right)+10
\end{aligned}
$$

WTO, WTO en sd(WTO) zijn hierbij gedefinieerd op analoge wijze als de WMVvariabelen bij de berekening van het mobiliteitsvemogen. Wanneer de overige drie behoefte-indicatoren op analoge wijze zijn bepaald, wordt de employability behoefte $\left(E B_{i}\right)$ als volgt berekend:

$$
E B_{i}=\frac{T O_{i}+O O_{i}+D O_{i}+E O_{i}}{4}
$$

\section{Confrontatie M.O.I. en employability behoefte (hoofdstuk 5)}

In hoofdstuk 5 wordt de aanwezige employability in de bedrijfssectoren voor iedere doelgroep vergeleken met de employability behoefte die er in de bedrijfssectoren bestaat. Daartoe wordt de volgende confrontatie-indicator $\left(c_{i d}\right)$ berekend:

$$
C_{i d}=\left[\frac{M O I_{i d}}{E B_{i}}\right] * 100
$$

\section{Effectueringscondities per bedrijfssector (hoofdstuk 6)}

De mogelijkheden die er in een sector bestaan om de aanwezige employabilility van de werkenden in de sector te effectueren komen in het zesde hoofdstuk aan de orde. Er zijn twee indicatoren, te weten: de opleidingsinspanningen per bedrijfssector en de verwachte uitbreidingsvraag. Beiden vergemakkelijken de effectuering 
van de employability van de werknemers. In eerste instantie worden deze twee indicatoren genormaliseerd. Voor de scholingsinspanningen gebeurt dit als volgt:

$S I_{i}=100^{\star}\left[\frac{S I_{i}^{N}}{\overline{S l^{N}}}\right]$ waarbij

$S I_{i}^{N}=\left[\frac{W S I_{i}-W S I}{s d(W S I)}\right]-M I N\left(\frac{W S I_{i}-\overline{W S I}}{s d(W S I)}\right)+10$

$W S I_{i}, \overline{W S I}$ en $s d(W S I)$ zijn weer analoog gedefinieerd als de WMV-variabelen bij de berekening van de mobiliteitsbereidheid.

De uitbreidingsvraag per bedrijfssector wordt op dezelfde manier berekend en gecombineerd met de scholingsinspanningen-indicator. Zo ontstaat een samenvattende indicator voor de effectueringscondities per bedrijfssector:

$E C_{i}=\frac{S I_{i}+U V_{i}}{2}$

Berekening S.E.I. (hoofdstuk 7)

De S.E.I. wordt bepaald door de confrontatie van de aanwezige employability (per bedrijfssector en doelgroep) en de behoefte aan employability (per bedrijfssector) te combineren met de effectueringscondities per bedrijfssector:

S.E.I. $\cdot{ }_{\cdot i d}=\frac{C_{i d}{ }^{*} E C_{i}}{100}$ 